Coordenadores:

Leonardo de Andrade Alberto Pablo Martins Bernardi Coelho

Autores:

Ana Beatriz do Amaral Souza André Serotini

Beatriz de Lima Cardoso Bruna Cabrera de Bonito

Cristina Veloso Castro Danilo Vieira Vilela Eduarda Possebom Elias Gabriela Nunes de Oliveira

Giovanna Chaves Leal Leonardo de Andrade Alberto Letícia Ribeiro de Moraes Loyana Christian de Lima Tomaz Marcelo Braghini Maria Clara da Guarda Queiroz Marildo Domingos da Silva Pablo Martins Bernardi Coelho Rafaella Pereira Frujuelle Rafaella Tôrres Vitoi Rozaine Aparecida Fontes Tomaz Tainá Fagundes Lente Tamires Eduarda Santos

\title{
ESTUDOS INTERDISCIPLINARES EM CIÊNCIAS SOCIAIS APLICADAS
}
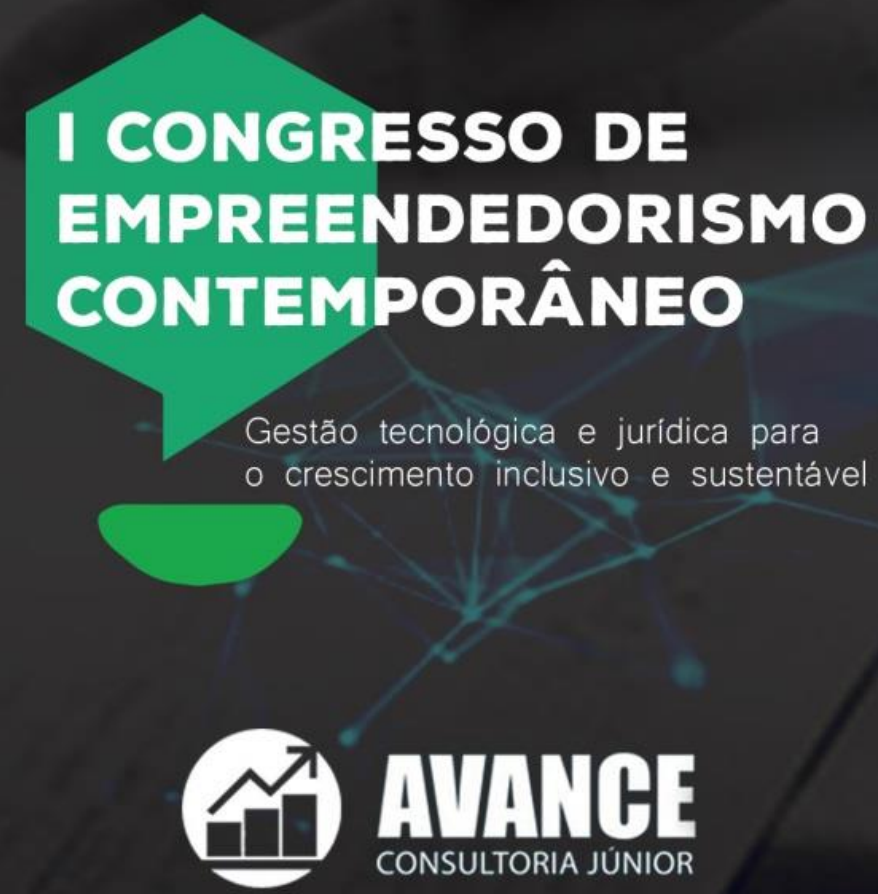


\title{
Leonardo de Andrade Alberto
}

Pesquisador bolsista em Iniciação Científica do Programa Institucional de Apoio à Pesquisa-

PAPq/UEMG. Pesquisador vinculado ao Laboratório Americano de Estudos

Constitucionais Comparados (LAECC). Presidente da Gestão 2019 da Avance Consultoria Júnior.

Graduação em Direito em andamento pela Universidade do Estado de Minas Gerais-UEMG/Frutal. Formado em Técnico em Administração pela Escola Técnica Elias Nechar. Já atuou como estagiário em órgãos do executivo, legislativo e da polícia judiciária. Interessa-se por temas que versam sobre Direitos Humanos, Direito Internacional Público, Direito Constitucional, Direito Penal, Direito Comparado e Direito Digital com experiência em pesquisa e publicação.

\section{Pablo Martins Bernardi Coelho}

Professor Adjunto do curso de Direito da Universidade do Estado de Minas Gerais - UEMG. Professor do curso de Direito da Faculdade Presidente Antônio Carlos - UNIPAC/Uberlândia. Doutor e Mestre em História pela Universidade Estadual Paulista “Júlio de Mesquita Filho”- UNESP. Especialização em Direito Público Aplicado em andamento pela Escola Brasileira de Direito (EBRADI). Graduado em História (UNESP), Direito (UNIRP) e Ciências Sociais (UNESP). Atua principalmente nos seguintes temas: Direito Constitucional, Direito Administrativo, Direito Eleitoral, Municipal e Ciência Política. Participa como membro da ALACIP (Associação Latino Americana de Ciência Política). Pesquisador vinculado ao Laboratório Americano de Estudos Constitucionais Comparados (LAECC) e líder do grupo de pesquisa Cultura, Direito \& Sociedade da UEMG. É avaliador MEC inserido no Banco de Avaliadores (BASis) do Sistema Nacional de Avaliação da Educação Superior (Sinaes) para os cursos de Direito.

\section{ESTUDOS INTERDISCIPLINARES EM CIÊNCIAS SOCIAIS APLICADAS}

\author{
I Congresso de Empreendedorismo Contemporâneo: Gestão tecnológica e \\ jurídica para o crescimento inclusivo e sustentável
}

\section{AVANCE CONSULTORIA JÚNIOR}

Av. Prof. Mário Palmério, 1.001, Bloco A, piso 2, sala 07- UEMG

Frutal, Minas Gerais, Brasil

avance.mej@gmail.com

www.avancejr.com.br 


\title{
AVANCE CONSULTORIA JÚNIOR
}

Empresa Júnior de consultoria empresarial e jurídica vinculada à Universidade do Estado de Minas Gerais- UEMG/Frutal

\section{GESTÃO 2019}

\section{Presidente}

Leonardo de Andrade Alberto

\section{Diretora Administrativo-financeiro}

Isadora dos Santos Silva

\section{Diretora Jurídica}

Brenda Maria Silveira Fuini

\author{
Diretora de Gestão de Pessoas \\ Beatriz Caverzan
}

\section{Diretor de Projetos}

Gederson Teodoro de Queiroz

\section{Coordenador Administração}

Prof. Dr. João Paulo Leonardo de Oliveira

\section{Coordenador Direito}

Prof. Dr. Pablo Martins Bernardi Coelho 
Dados Internacionais de Catalogação na Publicação (CIP) (Even3 Publicações, PE, Brasil)

E89 Estudos Interdisciplinares em Ciências Sociais Aplicadas / coordenadores: Leonardo de Andrade Alberto e Pablo Martins Bernardi Coelho. - 1. ed. - Minas Gerais: Avance Consultoria Júnior, 2019.

1 livro digital ; $141 \mathrm{p}$.

Modo de acesso: Internet.

DOI: $10.29327 / 56866$

ISBN: 978-85-5722-373-8

1. Ciências Sociais Aplicadas 2. Direito. 3. Administração geral. I. ALBERTO, Leonardo de Andrade. II. COELHO, Pablo Martins Bernardi. III. Avance Consultoria Júnior. IV. Título.

CDD 300

CDU 340

*Todo e qualquer conteúdo dos capítulos desta obra é de inteira responsabilidade dos seus respectivos autores. Assim, a Avance Consultoria Júnior e o corpo editorial não se responsabilizam por eventual uso indevido da propriedade intelectual alheia (ou outros).

Caso haja uso indevido, eventuais medidas deverão ser encaminhadas e direcionadas ao(s) autor(es) do respectivo trabalho. 


\section{CORPO EDITORIAL}

\section{COORDENADORES}

Leonardo de Andrade Alberto

Pablo Martins Bernardi Coelho

\section{DIREÇÃO DE ARTE}

Ana Carolina Morais Pereira da Silva

\section{TRADUÇÃO LÍNGUA INGLESA}

Beatriz de Lima Cardoso

\section{AUTORES}

Ana Beatriz Do Amaral Souza André Serotini

Beatriz De Lima Cardoso

Bruna Cabrera De Bonito

Cristina Veloso Castro

Danilo Vieira Vilela

Eduarda Possebom Elias

Giovanna Chaves Leal

Gabriela Nunes de Oliveira

Leonardo De Andrade Alberto
Loyana Christian De Lima Tomaz

Marcelo Braghini

Maria Clara Da Guarda Queiroz

Marildo Domingos da Silva

Pablo Martins Bernardi Coelho

Rafaella Pereira Frujuelle

Rafaella Tôrres Vitoi

Rozaine Aparecida Fontes Tomaz

Tainá Fagundes Lente

Tamires Eduarda Santos

Letícia Ribeiro De Moraes 

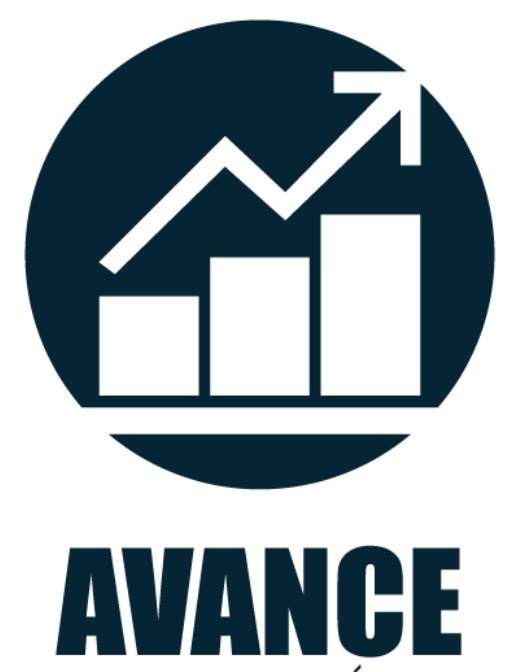

CONSULTORIA JÚNIOR

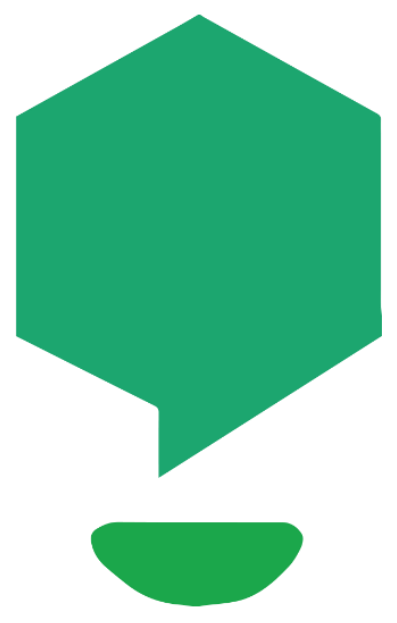




\section{SUMÁRIO}

\section{Capítulo 1}

A arbitragem como meio de solução de litígios envolvendo as empresas estatais no Brasil / The arbitration as a way of dispute resolution involving state-owned enterprises in Brazil.

Bruna Cabrera de Bonito; Danilo Vieira Vilela

\section{Capítulo 2}

Aspectos jurídicos de compliance e proteção ambiental / Legal aspects of compliance and environmental protection.

André Serotini. 24-35

\section{Capítulo 3}

A possibilidade de acumulação de cargos públicos no Brasil sob a ótica constitucional e administrativa / The possibility of public offices accumulation in Brazil from constitutional and administrative perspective.

Danilo Vieira Vilela; Giovanna Chaves Leal.... $36-46$

\section{Capítulo 4}

Whatsapp como instrumento de conciliação nas reclamações trabalhistas / WhatsApp as an instrument of conciliation in labor demands.

Letícia Ribeiro de Moraes; Marcelo Braghini.

\section{Capítulo 5}

A responsabilidade do Estado nos casos de omissão fiscalizatória ambiental / The State's liability in case of environmental inspectional omission.

Leonardo de Andrade Alberto; Beatriz de Lima Cardoso; André Serotini.... $59-69$

\section{Capítulo 6}

A constitucionalidade do teto remuneratório nos casos de acumulação lícita de cargos públicos no Brasil / The wage cap's constitutionality in the lawful cases of public offices accumulation in Brazil.

Danilo Vieira Vilela; Ana Beatriz do Amaral Souza; Rafaella Pereira Frujuelle......70-81

\section{Capítulo 7}

Direito do consumidor: a indenização por dano moral nas relações de consumo virtuais / Consumer Law: Indemnity for moral damage in virtual consumer relations. Tamires Eduarda Santos; Rafaella Tôrres Vitoi; Pablo Martins Bernardi Coelho....82-92 


\section{Capítulo 8}

A importância da logística reversa no manejo de resíduos sólidos: os benefícios ao ciclo produtivo / The importance of reverse logistics in solid waste management: the benefits to the production cycle.

Eduarda Possebom Elias; Maria Clara da Guarda Queiroz; Cristina Veloso Castro. 93-103

\section{Capítulo 9}

A Medida Provisória da liberdade econômica (MP 881/2019) convertida na lei $\mathbf{n}^{\circ}$ 13.874/2019 e a alteração do art. 1052 do Código Civil / The Provisional Measure of economic freedom (MP 881/2019) converted in Law n. 13.874/2019 and the modification of art. 1052 Civil Code's.

Loyana Christian de Lima Tomaz; Rozaine Aparecida Fontes Tomaz; Tainá Fagundes Lente. 104-117

\section{Capítulo 10}

O uso do plano de negócios para análise de viabilidade financeira de um empreendimento esportivo / The use of the business plan for financial viability analysis of a sportive enterprise.

Gabriela Nunes de Oliveira; Marildo Domingos da Silva $118-137$ 


\section{PREFÁCIO}

A presente obra é resultado do desenvolvimento de trabalhos apresentados no I Congresso de Empreendedorismo Contemporâneo, evento idealizado e promovido pela Avance Consultoria Júnior, empresa júnior dos cursos de Administração e Direito da Universidade do Estado de Minas Gerais- UEMG/Frutal.

O evento abrangeu grandes áreas do conhecimento e tencionou voltar olhares para as questões inclusivas e sustentáveis através da tecnologia e do ambiente jurídico, com o fim de debater a forma como os avanços impactam as esferas do empreendedorismo.

Nesta perspectiva, a obra "Estudos interdisciplinares em ciências sociais aplicadas" é formada por trabalhos considerados os melhores do evento, cujos autores foram convidados a desenvolver o artigo para publicação.

Assim, os capítulos expressam, única e exclusivamente, o ponto de vista do(s) seu(s) autor(es) sobre determinado tema afigurando-se contribuição de extrema relevância ao debate contemporâneo.

Por fim, cumpre informar que todos os resumos expandidos apresentados no evento encontram-se nos anais publicados no sítio eletrônico www.avancejr.com.br/icec/ sob ISBN nº 978-85-572-2263-2.

\section{Leonardo de Andrade Alberto}

Diretor Presidente

Avance Consultoria Júnior 

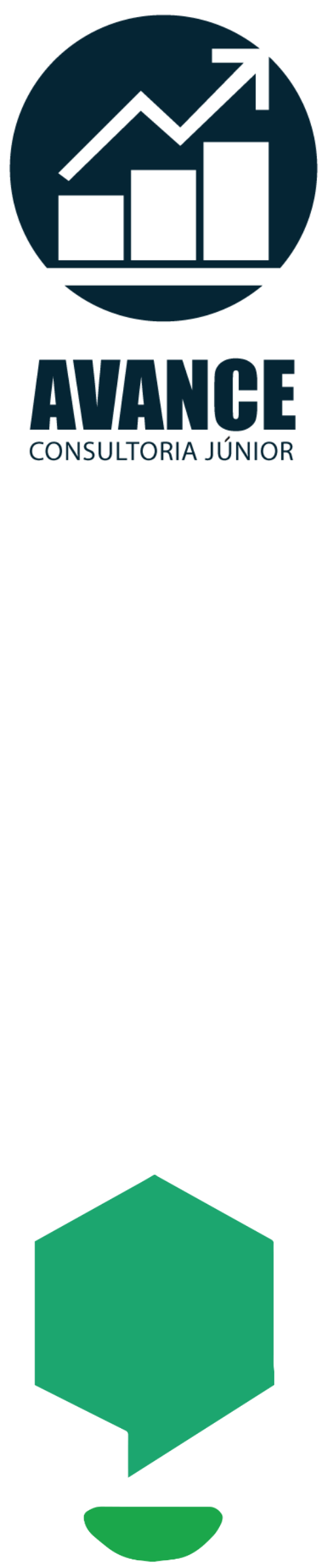


\section{A ARBITRAGEM COMO MEIO DE SOLUÇÃO DE LITÍGIOS ENVOLVENDO AS EMPRESAS ESTATAIS NO BRASIL}

The arbitration as a way of dispute resolution involving state-owned enterprises in Brazil

\section{Bruna Cabrera De Bonito}

Pesquisadora bolsista em Iniciação Científica pelo Conselho Nacional de Desenvolvimento Científico e Tecnológico (CNPq). Foi bolsista de Iniciação Científica da Fundação de Amparo à Pesquisa de Minas Gerais (FAPEMIG). Graduação em Direito em andamento pela Universidade do Estado de Minas Gerais-UEMG/Frutal. Já atuou como estagiária no Ministério Público do Estado de Minas Gerais-MPMG/Frutal. Interessa-se por temas que versem sobre Direito Administrativo e Métodos alternativos de solução de litígio. E-mail: bruna_bonito@hotmail.com

\section{Danilo Vieira Vilela}

Professor efetivo da Universidade do Estado de Minas Gerais (UEMG). Doutor em Direito Político e Econômico pela Universidade Presbiteriana Mackenzie (Bolsista Mackenzie). Mestre em Direito Obrigacional Público e Privado pela Universidade Estadual Paulista Júlio de Mesquita Filho UNESP (Bolsista FAPESP), Especialista em Direito Processual (UEMG), Especialista em Direito Penal e Processual Penal (UCDB), Especialista em Direito Empresarial e Advocacia Empresarial (Anhanguera-Uniderp) e MBA em Gestão Empresarial (UNESC). Professor em cursos de pósgraduação e em cursos preparatórios para concursos. Advogado e Árbitro no CBLE - Centro Brasileiro de Litígios Econômicos. E-mail: danilo.vilela@uemg.br

Resumo: Tendo como problema central a análise das vantagens da utilização de meios alternativos de solução de controvérsias nos litígios envolvendo as empresas estatais, o objetivo do presente trabalho é demonstrar, inicialmente, a importância das estatais para o desenvolvimento nacional, através do papel histórico desempenhado por elas no Brasil. A seguir, busca-se demonstrar em que medida viabilizar um meio adequado e eficiente de solucionar seus litígios pode garantir a execução apropriada do papel constitucionalmente a elas atribuído. Dentre aqueles meios, o presente estudo enfocará a arbitragem. Em seguida, serão examinadas as peculiaridades da via arbitral ao envolver o Poder Público, visto que as empresas estatais se inserem na Administração Pública Indireta, além das possíveis vantagens da utilização de tal meio. Metodologicamente, pauta-se pelo enfoque descritivo, utilizando-se da pesquisa bibliográfica baseada em análise de artigos científicos, legislação e doutrinas relacionadas ao tema. A título de conclusões, é possível evidenciar que as vantagens proporcionadas pela via arbitral às empresas estatais possibilitam benefícios internos, como celeridade, tecnicidade e confiabilidade do cumprimento das obrigações contratuais, além de externos e macroeconômicos, como investimentos privados na seara pública que podem se refletir no impulsionamento do desenvolvimento nacional. O presente trabalho é resultado de bolsa de iniciação científica concedida pelo Conselho Nacional de Desenvolvimento Científico e Tecnológico (CNPq), edital 01/2018 PIBIC/UEMG/CNPq.

Palavras-chave: Empresa estatal; Arbitragem; Desenvolvimento nacional. 
Abstract: Having as its central problem the analysis of the advantages of using alternative ways of dispute resolution in disputes involving state-owned companies, the aim of this paper is to demonstrate, initially, the importance of state-owned companies in national development, through their part in brazilian history. Then, we seek to demonstrate how enabling an adequate and efficient way of dispute resolution can ensure the proper execution of their constitutionally assigned role. Among those ways, this paper will focus on arbitration. After that, the peculiarities of the arbitration route will be examined when involving the Government, as stateowned companies are part of the Indirect Public Administration, as well as the advantages of its use. Methodologically, the paper is guided by the descriptive approach, using bibliographic research based on analysis of scientific articles, legislation and doctrines related to the matter. Finally, it is possible to highlight that the advantages provided by the arbitration to state-owned companies allow internal benefits, such as agility, technicality and reliability of contractual obligations, as well as external and macroeconomic, such as private investments in the public sector that may lead to the boosting of national development. This paper is the result of a scientific initiation scholarship granted by the National Council for Scientific and Technological Development (CNPq), public notice 01/2018 PIBIC/UEMG/CNPq.

Keywords: State-owned enterprise; Arbitration; National development.

\section{INTRODUÇÃO}

A ascensão do Estado Regulador, também chamado por Figueiredo (2014, p. 65-66) de Estado Democrático de Direito ou Neoliberal, foi caracterizada pela condição do Estado como regulamentador da Ordem Econômica. No Brasil, tal papel é resultado do princípio da livreiniciativa (art. 170 da CRFB/88), que estabelece como regra o exercício da atividade econômica pela iniciativa privada, competindo ao Estado a função de "estabelecer as regras disciplinadoras da ordem econômica com o objetivo de ajustá-la aos ditames da justiça social" (CARVALHO FILHO, 2017, p. 975), de modo a ratificar o comportamento a ser seguido pelo mercado (iniciativa privada).

Todavia, ainda que esta atuação indireta na seara econômica deva ser exercida de maneira majoritária, a Constituição da República (1988) permite que o Estado, de maneira subsidiária, seja por omissão ou ausência da iniciativa privada no alcance dos interesses coletivos, exerça diretamente a atividade econômica. Ademais, essa atividade estatal direta se sujeita a dois requisitos, quais sejam, “quando necessária aos imperativos da segurança nacional ou a relevante interesse coletivo" (art. 173 da CRFB/88). Por fim, presentes tais pressupostos, caberá à Administração Pública Direta (União, Estados, Distrito Federal ou Municípios) criar os meios para sua efetivação, que são as empresas estatais.

Assim, entende-se por empresas estatais "todas as entidades, civis ou comerciais, de que o Estado tenha o controle acionário, diretamente ou por meio de outra entidade da administração 
indireta" (DI PIETRO, 2017, p. 601). Tal definição abrange a forma de empresas públicas, sociedades de economia mista, suas subsidiárias e demais empresas controladas pelo Estado.

Baseado na importância de tais entes para o desenvolvimento nacional, visto que abarcados pelo texto constitucional, as empresas estatais desempenham "um significativo papel na dinamização da economia de um país, sendo frequentemente indutoras de desenvolvimento, a depender do tipo de atividade e da forma como é desempenhada" (MAXIMIANO; NOHARA, 2017, p. 98).

Nesse sentido, no decurso do presente trabalho será demonstrado o histórico das empresas estatais no início da industrialização do país até os dias de hoje, além de sua importância para o desenvolvimento econômico nacional. Posteriormente, baseado nessa importância, quais as possibilidades do uso de um método de solução de contendas alternativo à jurisdição estatal no cenário em que a maioria das estatais ocupa, que é o mercado. Dentre esses meios, em razão da seara econômica ocupada por tais entes, o trabalho enfocará a via arbitral. Para isso, será apresentado o surgimento da justiça arbitral no mundo e no Brasil, passando pelas discussões doutrinárias e jurisprudenciais sobre o tema, terminando com as aprovações legislativas das leis $n^{\circ} 9.307$ de 1996, a lei $n^{\circ} 13.129$ de 2015 e a lei $n^{\circ} 13.303$ de 2016. Por fim, as conclusões sobre a intersecção das empresas estatais e o procedimento arbitral.

\section{O PAPEL DAS EMPRESAS ESTATAIS NO DESENVOLVIMENTO ECONÔMICO}

A empresa estatal sustenta um papel importante e duradouro na história do Brasil. Segundo Giambiagi e Além (2008, p. 64), a "participação do Estado nas atividades econômicas no Brasil não decorreu de uma atitude deliberada do Estado com vistas a ocupar o espaço do setor privado", mas sim, inevitavelmente, para suprir a incapacidade do setor privado em se expandir com as exigências do desenvolvimento da época.

O objetivo do Estado era viabilizar, sobretudo, um sistema de desenvolvimento da produção econômica em razão da baixa técnica das empresas privadas nacionais e da subjugação do Brasil por outros países à condição colonial, uma vez o Estado era o único ator capaz de integrar o capitalismo mundial (OCTAVIANI; NOHARA, 2019, p. 47).

Por todo seu histórico, a empresa estatal, de modo majoritário, esteve ligada ao desenvolvimento brasileiro. Seja para o estímulo da indústria nacional a fim de substituir importações, motivação nacionalista para garantir soberania nacional ou como estratégica de política macroeconômica (GIAMBIAGI; ALÉM, 2008, p. 66-71). 
Levando em conta o cenário mundial marcado pela intervenção estatal de 1960 a 1970, no Brasil, as empresas estatais foram os principais mecanismos utilizados para a estratégia “crescimento com endividamento" (growth-cum-debt) (GIAMBIAGI; ALÉM, 2008, p. 72). Essa estratégia acarretou às estatais a restrição ao acesso de crédito internamente, induzindo-a a buscá-lo fora do país, obtendo como resultado o aumento do passivo, ou seja, das dívidas.

Além disso, houve como resultado da "deterioração da receita tributária e da tentativa de redução do déficit público, um esforço de contenção de gastos orçamentários, que se refletiu em uma redução significativa dos aportes de capital às empresas estatais" (GIAMBIAGI; ALÉM, 2008, p. 72).

Congruente com esse cenário, em razão da dupla face (pública e privada) da empresa estatal, na esfera lucrativa, não obteve muito sucesso. Isto porque em muitos momentos teve que deixar de lado sua face privada (pessoa jurídica de direito privado) em favor de interesses públicos e objetivos nacionais e econômicos (macroeconomia) (GIAMBIAGI; ALÉM, 2008, p. 72). Um exemplo disso é a venda de produtos a preços subsidiados pelas empresas estatais durante todo o procedimento de industrialização brasileira, com a finalidade de estímulo ao desenvolvimento de variados setores (GIAMBIAGI; ALÉM, 2008, p. 393-394).

Por outro lado, em razão de tais entes públicos não tomarem como prioritário somente metas de lucro, adquirem maior liberdade para efetuar "pesquisa básica, buscar tecnologias e implementar inovações mais amplas, arriscadas e de retorno de longo prazo" (PAULA, 2018, p. 118). Como demonstra a Pesquisa de Inovação Tecnológica de 2008 (baseado nos anos 20052008) feita pelo Instituto Brasileiro de Geografia e Estatística (IBGE), constatando que as empresas estatais federais apresentaram uma taxa de inovação tecnológica de $68,1 \%$ e em outros tipos de empresas essa taxa foi de 38,6\% (PAULA, 2018, p. 117).

Em âmbito nacional, as empresas estatais apresentam também uma influência relevante nas áreas sociais, econômicas e políticas:

\begin{abstract}
Sociais, pela geração de empregos e políticas de pessoal, em geral oferecendo condições acima dos padrões do mercado privado, funcionando como um direcionador; econômicas, pois representam fontes importantes de receitas para os governos pelos dividendos distribuídos, pelo poder de apoiar setores e programas de desenvolvimento, e pelos próprios investimentos que realizam; e políticas, por se qualificarem como atores de destaque das composições políticas e das barganhas na formação das coalizões de poder. (FONTESFILHO, 2018, p. 211).
\end{abstract}

Nesse sentido, observam Octaviani e Nohara (2019) que a própria existência da empresa estatal “[...] é uma política pública e tal empresa só existe, como um todo, para realizar a política pública econômica específica e juridicamente determinada pela Constituição [...]. 
A tarefa constitucionalmente determinada ao Estado brasileiro é (como se compreende dos comandos dos artigos $3^{\circ}, 170$ e 219 da Constituição de 1988, entre tantos outros), portanto, a superação do subdesenvolvimento, da sua condição periférica, ou seja, uma tarefa mais ampla, complexa e transformadora do que as que são geralmente atribuídas ao Estado Social tradicional [...]. (BERCOVICI; OCTAVIANI, 2017, p. 80).

Ainda, conforme menciona a Lei das Estatais,

[...] há a previsão do art. 27 [da lei ${ }^{\circ} 13.303 / 16$ ] de que a empresa pública e a sociedade de economia mista terão função social de realização do interesse coletivo ou de atendimento a imperativo da segurança nacional em reprodução do art. 173 da Constituição [...]. O $\S 1^{\circ}$ do art. 27 enfatiza que a realização do interesse coletivo deverá ser orientada pra o alcance do bem-estar econômico e para a alocação socialmente eficiente dos recursos geridos pela empresa pública e pela sociedade de economia mista, bem como para (1) a ampliação economicamente sustentada do acesso de consumidores aos produtos e serviços da empresa pública ou sociedade de economia mista, e (2) o desenvolvimento ou emprego de tecnologia brasileira para a produção e oferta de produtos e serviços da empresa pública ou sociedade de economia mista, sempre de maneira economicamente justificada. (OCTAVIANI; NOHARA, 2019, p. 74-75).

Essa importância do setor empresarial estatal revela-se também através do número de empresas estatais federais brasileiras, que é de $134^{1}$ (BRASIL, 2019), e sua variedade na atuação (financeira ou produtiva), dando ao Estado brasileiro importância na fixação dos rumos da economia nacional (KLIASS, 2018, p. 24).

Figura 1. Setores de atuação das empresas estatais federais em maio de 2019

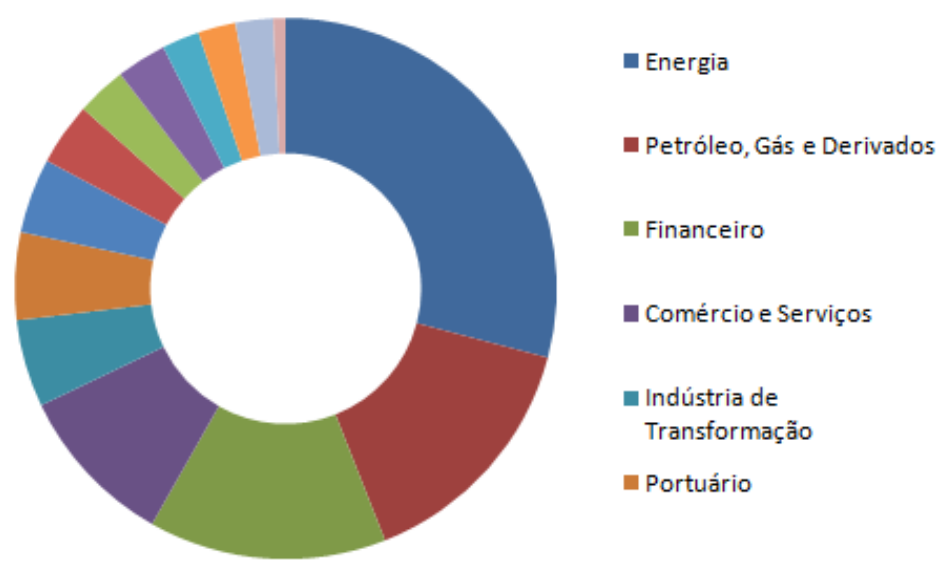

Fonte: Brasil (2019) e elaborado pela autora no software Microsoft Excel.

Ainda, em âmbito mundial, segundo Grossi, Papenfuß e Tremblay (2015, p. 276), em muitos países em âmbito local, a maioria dos trabalhos do setor público são prestadas através

\footnotetext{
${ }^{1}$ Dados referentes ao mês de junho de 2019.
} 
das empresas estatais (ou similares), além de tais entes representarem dez por cento do PIB mundial e uma venda conjunta de 3,6 trilhões de dólares em 2011 (GROSSI; PAPENFUß; TREMBLAY, 2015, p. 274-275).

Baseado no demonstrado acima, resta evidenciada a relevância das empresas estatais para o desenvolvimento nacional. Assim, garantir a tais entes alternativas de resolução de seus conflitos adequadas ao papel desempenhado pode influenciar e impulsionar positivamente o país. Por fim, somado ao cenário ocupado pela maioria desses entes que é o mercado, que depende de soluções rápidas, especializadas e técnicas, colocam a arbitragem em ponto de destaque.

\section{A ARBITRAGEM NAS EMPRESAS ESTATAIS}

Segundo Scavone Júnior (2018, p. 18) a "arbitragem é um dos mais antigos meios de composição de conflitos pela heterocomposição, ou seja, a solução do conflito por um terceiro imparcial". Inicialmente, o desenvolvimento desse mecanismo ocorreu em razão da origem da civilização e do progresso social, momento em que deixou-se de lado o uso da força e violência para a transferência da decisão do litígio a uma autoridade (ZAPPALÁ, 2011, p. 103).

Carmona (2011, p. 682) salienta que o desenvolvimento da arbitragem não ocorreu em razão de dificuldades do Poder Judiciário, uma vez que a arbitragem também se aprimorou em países em que a justiça estatal funciona de maneira efetiva. Mas, tal crescimento se deu por conta dos litigantes escolherem a justiça arbitral como mecanismo mais adequado na resolução de seus conflitos, porque possibilita a escolha do tempo e modo em que se realizará tal procedimento, liberdades que não abrangem os juízes (CARMONA, 2012, p. 582).

No ordenamento jurídico brasileiro, o procedimento arbitral foi introduzido em 1996 com a lei $n^{\circ} 9.307$ (Lei da Arbitragem), mas tal instituto está presente no Brasil desde a colonização portuguesa. Essa lei, após declarada sua constitucionalidade em 2001 pelo Supremo Tribunal $\mathrm{Federal}^{2}$, consolidou a arbitragem como um meio alternativo a jurisdição estatal. Isto porque findou a necessidade de homologação judicial da sentença arbitral e a ratificação da cláusula arbitral por meio do compromisso arbitral, grandes impeditivos para a celeridade proporcionada pela via arbitral e que desestimulava sua utilização.

De modo geral, no que tange ao procedimento arbitral, o artigo $3^{\circ}$ da Lei de Arbitragem dispõe que as partes deverão iniciá-lo através de uma convenção arbitral, ou seja, uma

\footnotetext{
${ }^{2}$ Agravo Regimental na Sentença Estrangeira 5.206/DF.
} 
manifestação da vontade das partes em se submeter a via arbitral. Tal convenção pode ser firmada antes do surgimento do litígio, através da cláusula arbitral, como por exemplo na inserção desta última em um contrato que dispõe que qualquer eventual contenda será solucionada por meio da arbitragem. Também, pode ser feita após o surgimento do litígio através do compromisso arbitral, no qual as partes decidem submeter o dissídio a tal procedimento.

Cabe ressaltar que a justiça arbitral não pode ser exercida de maneira compulsória, ou seja, ninguém pode ser obrigado a se submeter a ela. Entretanto, a partir do momento em que as partes convencionarem (seja por meio de cláusula ou compromisso) tal procedimento, baseando-se na manifestação livre e consciente e no princípio da autonomia da vontade, o pactuado torna-se obrigatório (pacta sunt servanda). Como ratificou recentemente o Superior Tribunal de Justiça:

RECURSO ESPECIAL. DIREITO CIVIL E PROCESSUAL CIVIL. ARBITRAGEM. CLÁUSULA COMPROMISSÓRIA. COMPETÊNCIA DO JUÍZO ARBITRAL. PRINCÍPIO KOMPETENZ-KOMPETENZ. PRECEDENTES. DISSÍDIO NOTÓRIO. 1.Contrato celebrado entre as partes com cláusula compromissória expressa, estabelecendo a arbitragem como instrumento para solução das controvérsias resultantes de qualquer disputa ou reivindicação dele decorrente, e impossibilitando que as partes recorram ao Poder Judiciário para solucionar contenda relativa ao seu cumprimento. (Recurso Especial $\mathrm{n}^{\circ}$ 1.598.220-RN (2016/0115824-0), Relator : Min. Paulo De Tarso Sanseverino, Data do Julgamento: 25 jun. 2019) (negrito nosso).

Ainda, sobre o árbitro, a lei nº 9.307/96 dispõe que deverá ser pessoa capaz e que tenha a confiança das partes (art. $1^{\mathrm{o}}$ e 13), não elencando nenhum outro requisito. Dessa forma, possibilitando liberdade às partes na escolha do julgador, além de propiciar a escolha de um julgador técnico e com conhecimento específico a respeito do tema em litígio.

No que tange ao Poder Público figurar como parte, no decorrer do procedimento arbitral, cabe observar algumas peculiaridades. Apesar de, em regra, a arbitragem dar a possibilidade de ser confidencial, por força do princípio da publicidade (art. 37, CRFB/88), em casos que envolver a administração pública, em regra, deverá ser público.

Além disso, para a realização de tal procedimento, não é necessário realizar processo licitatório, em razão da natureza especial, mas não deve ocorrer de maneira discricionária. Nesse sentido, Carmona (2016, p. 11) e Talamini e Franzoni disciplinam que a escolha do administrador deve ser "pautada em parâmetros objetivos e fundamentados, que visem ao melhor resultado para o processo arbitral" (2017, p. 31), como por exemplo a tradição do órgão julgador, experiência e especialização do árbitro no assunto em tela. Outro tópico que merece 
destaque é a arbitrabilidade subjetiva e objetiva, sendo a primeira a capacidade das partes em se vincular à arbitragem; e a segunda os assuntos e dissídios que podem ser objeto desse procedimento, que incluem direitos patrimoniais disponíveis.

Todavia, antes de se consolidar como um meio de solução de litígios para o Poder Público, a justiça arbitral teve que superar alguns pontos, como pontua Sombra (2018, p. 5657): (i) a inafastabilidade do controle jurisdicional ou reserva de jurisdição; (ii) o princípio da legalidade administrativa; e (iii) a indisponibilidade/supremacia do interesse público.

O primeiro trata sobre a ideia de impossibilidade de um direito ou lesão não ser levada à apreciação judicial, conforme disposição constitucional. Todavia, por conta do procedimento arbitral abranger somente direitos patrimoniais disponíveis (ou seja, direitos relacionados ao patrimônio e ainda que a parte pode abrir mão, como por exemplo direitos que podem ser objeto de um contrato) e ser de liberalidade das partes se submeterem a ele, no momento em que decidem levar seu litígio para a via arbitral através de uma cláusula arbitral por exemplo, tal demanda não pode mais ser objeto de ação judicial.

O segundo tópico trata sobre a ausência de lei que disciplinava o tema para o Poder Público, assunto que se findou com a edição da lei nº 13.129 em 2015. Já o terceiro foi o ponto de maior discussão. O princípio da indisponibilidade do interesse público dava a ideia de que os interesses públicos, de modo geral, não eram passíveis de disposição, entendimento esse de uma parcela de doutrinadores, e inclusive do Tribunal de Contas da União na época. Todavia, segundo explica Eros Grau (2002, p. 823), o interesse público se divide em primário e secundário, sendo o primeiro indisponível por se tratar de interesses dos administrados como por exemplo segurança, saúde, educação. Já o interesse público secundário abrange os interesses da própria Administração, sendo passíveis de disposição e, portanto, objetos do procedimento arbitral.

Superados tais pontos, apesar de decisões jurisprudenciais anteriores ${ }^{3}$, a expressa permissividade para utilização da via arbitral pelo Poder Público somente realizou-se com a edição da lei no 13.129 de 2015, que reformou a Lei da Arbitragem. A primeira dispõe que "a administração pública direta e indireta poderá utilizar-se da arbitragem para dirimir conflitos relativos a direitos patrimoniais disponíveis" (art. $\left.1^{\circ}, \S 1^{\circ}\right)$. Ainda, com o Estatuto das Estatais (lei $n^{\circ} 13.303$ ) em 2016, permitiu-se também a realização de tal procedimento no âmbito interno

\footnotetext{
${ }^{3}$ Casos jurisprudenciais que demonstram o entendimento judicial antes do respaldo legislativo de 2015: Organização Lage em 1973 (STF, AI n 52.181/GB, relator Ministro Bilac Pinto), AES Uruguaiana em 2005 (STJ, REsp n. ${ }^{\circ}$ 612.439/RS, relator Ministro João Otávio de Noronha) e caso Compagás em 2011 (STJ, REsp n. ${ }^{\circ}$ 904.813/PR, relatora Mínistriq Nancy Andrighi)
} 
das empresas estatais, ao mencionar que "poderá solucionar, mediante arbitragem, as divergências entre acionistas e a sociedade, ou entre acionistas controladores e acionistas minoritários, nos termos previstos em seu estatuto social" (art. 12, § único). Além da Lei das S/As, que regem as sociedades de economia mista sob a forma de sociedades anônimas, que previa a possibilidade de utilizar a via arbitral para dissídios internos (art. 109, § $3^{\circ}$ ), semelhante a lei $n^{\circ} 13.303 / 16$.

Somado a essas possibilidades, Talamini e Franzoni ainda pontuam casos em que a arbitragem pode ser utilizada pelas empresas estatais:

(i) para a solução de conflitos internos às empresas públicas, quando o capital social dessas for titularizado por mais de uma pessoa jurídica de direito público interno ou contar com a participação minoritária de algum ente da Administração Pública indireta, nos termos do parágrafo único do art. $3^{\circ}$ da Lei 13.303; (ii) os conflitos, também internos, entre as empresas públicas e os entes que a controlam; (iii) os conflitos das empresas públicas ou sociedades de economia mista com terceiros (conflitos externos). (TALAMINI; FRANZONI, 2017, p. 15).

Tratando agora sobre as aplicações práticas, mesmo que a cultura brasileira seja a busca ao Judiciário em casos de pacificação social, a construção de uma mentalidade mais adepta a formas alternativas de solução de conflitos no Brasil (sobretudo na esfera empresarial) fez com que o país angariasse uma posição de destaque no ranking da Câmara de Comércio Internacional. No ano de 2006 as empresas nacionais ocuparam a quarta posição entre 142 países que mais utilizaram a arbitragem no tocante ao volume de procedimentos (TIMM; SILVA, 2011, p. 50-51). Dessa forma, apesar do superego vivido pela jurisdição estatal que acarreta a limitada utilização da arbitragem, a mudança no protagonismo do juiz ainda pode fazer com que a via arbitral seja utilizada de maneira muito mais abrangente.

Por fim, ao analisar as possibilidades do uso da arbitragem nas empresas estatais, notase a possibilidade de certas vantagens. A primeira vantagem é a celeridade. Ao comparar o tempo utilizado nas soluções de demandas judiciais com a arbitragem, a última ganha destaque, isto porque enquanto a jurisdição estatal tende a oferecer a pacificação do conflito em uma média de 105 meses $^{4}$ no $1^{\circ}$ grau, segundo dados do Conselho Nacional de Justiça (2018, p. 144), já na arbitragem caberá às partes escolher o tempo para emissão da sentença arbitral, que na ausência dessa disposição será de seis meses (art. 23 da lei $n^{\circ}$ 9.307/16). E ainda, o

\footnotetext{
${ }^{4}$ Os dados demonstrados são relativos ao $1^{\circ}$ grau de jurisdição (Varas Estaduais e Federais) com base no ano de 2017, sem prejuízo aos demais graus jurisdicionais recursais. Dessa forma, abrangendo a fase de conhecimento (com média de duração de 29 meses) e a fase de execução (com média de 76 meses de duração) (CNJ, 2018, p. 144) 
"exagerado processualismo, com rituais minuciosos e sempre ligados a prazos que impossibilitam decisões rápidas" (DALLARI, 2012, p. 887) como as inúmeras instâncias e possibilidade de recursos submetidos, fez com que a taxa de congestionamento na Justiça Estadual e Federal alcançasse o valor de 75\% e 73\%, respectivamente, no ano de 2018 (anobase 2017). Em razão de tal celeridade, mesmo que o preço da arbitragem seja conhecido por ser relativamente elevado no Brasil, o custo-benefício tende a se sobressair.

Outra vantagem é a possibilidade de especialidade do árbitro. Em razão da lei $\mathrm{n}^{\circ}$ 9.307/96 dispor sobre a liberdade das partes na escolha do julgador privado, possibilita que os últimos tenham formação específica na área e maior familiaridade com a matéria. Com isso, as decisões proferidas tendem a ser mais técnicas e acertadas, diminuindo os riscos da relação contratual. No caso em tela das empresas estatais,

\footnotetext{
É razoável supor, por exemplo, que o árbitro com anos de experiência na indústria petrolífera possa aferir com maior precisão os termos técnicos da contratação para exploração ou transporte de petróleo, além dos usos e costumes nos negócios da indústria petrolífera. A expectativa de que os contratos sejam interpretados por especialistas diminui os custos das partes relativos à negociação de contratos. (PUGLIESE; SALAMA, 2008, p. 20).
}

Mesmo que tais aspectos vantajosos se sobressaiam, cabe pontuar que não se exclui a possibilidade da má utilização de tal procedimento pelo gestor público, que mesmo dentro dos limites constitucionais legais utiliza-se da máquina pública para satisfação pessoal, merecendo destaque portanto que a justiça privada por si só não traz prejuízos exclusivos.

\section{CONCLUSÃO}

A finalidade desse artigo foi compreender as possibilidades e vantagens da utilização da arbitragem pelas empresas estatais no Brasil, de forma que os resultados obtidos no decorrer do texto apontam no sentido de que tal solução abre margem para a retomada do desenvolvimento nacional. Assim, ao relacionar a arbitragem com a atuação econômica das empresas estatais, tais ganhos se refletem em investimentos privados e estrangeiros no setor público, uma vez que a adoção da cláusula compromissória (convenção arbitral) demonstra confiabilidade para o cumprimento das obrigações firmadas. Dessa forma, a efetivação nos contratos acarreta efeitos macroeconômicos, fazendo com que o contrato seja mais atrativo para as partes e todo o mercado. A arbitragem configura, assim, um atrativo aos investidores, pois, além de sugerir uma atuação criativa e inovadora dos operadores jurídicos, evidencia a preocupação do Estado em garantir segurança jurídica para os investidores privados, 
significando importante passo para a configuração de um ambiente adequado ao desenvolvimento nacional.

\section{REFERÊNCIAS}

BERCOVICI, Gilberto; OCTAVIANI, Alessandro. Direito e Subdesenvolvimento. In: OCTAVIANI, Alessandro. Estudos, Pareceres e Votos de Direito Econômico. v. I. São Paulo: LiberArts, 2017.

BRASIL. Constituição da República Federativa do Brasil. Brasília, DF. Disponível em: www.planalto.gov.br/ccivil_03/constituicao/constituicaocompilado.htm. Acesso em: 27 ago. 2019.

BRASIL. Lei $\mathbf{n}^{\mathbf{0}}$ 6.404, de dezembro de 1976. Dispõe sobre as Sociedades por Ações. Brasília, DF. Disponível em: http://www.planalto.gov.br/ccivil_03/leis/16404consol.htm. Acesso em: 02 set. 2019.

BRASIL. Lei no 9.307, de 23 de setembro de 1996. Dispõe sobre a arbitragem. Brasília, DF. Disponível em: http://www.planalto.gov.br/ccivil_03/leis/L9307.htm. Acesso em: 29 ago. 2019.

BRASIL. Lei $\mathbf{n}^{\mathbf{0}}$ 13.129, de 25 de maio de 2015. Altera a lei n. 9.307, de 23 de setembro de 1996, e a lei n. 6.404, de 15 de dezembro de 1976 [...]. Brasília, DF. Disponível em: http://www.planalto.gov.br/ccivil_03/_Ato2015-2018/2015/Lei/L13129.htm. Acesso em: 29 ago. 2019.

BRASIL. Lei $\mathbf{n}^{\mathbf{0}}$ 13.303, de 30 de junho de 2016. Dispõe sobre o estatuto jurídico da empresa pública, da sociedade de economia mista e de suas subsidiárias [...]. Brasília, DF. Disponível em: http://www.planalto.gov.br/ccivil_03/_Ato2015-2018/2016/Lei/L13303.htm. Acesso em: 31 ago. 2019.

BRASIL. Ministério da Economia. Secretaria de Coordenação e Governança das Empresas Estatais - SEST. Panorama das estatais. 2019. Disponível em:

http://www.panoramadasestatais.planejamento.gov.br/QvAJAXZfc/opendoc.htm?document= paineldopanoramadasestatais.qvw\&lang=en-

US\&host=QVS\%40srvbsaiasprd07\&anonymous=true/. Acesso em: 30 ago. 2019

BRASIL. Superior Tribunal de Justiça (2. Turma). Recurso Especial 612.439/RS. Processo Civil. Juízo Arbitral. Cláusula compromissória. Extinção do processo. Art. 267, VII, do CPC. Sociedade de economia mista. Direitos disponíveis. Extinção da ação cautelar preparatória por inobservância do prazo legal para proposição da ação principal. Recorrente: AES Uruguaiana Empreendimentos Ltda. Recorrido: Companhia Estadual de Energia Elétrica - CEEE. Relator: Min. João Otávio Noronha, 25 de outubro de 2005. Disponível em: http://www.direitocom.com/wp-content/uploads/612439.pdf. Acesso em: 28 ago. 2019.

BRASIL. Superior Tribunal de Justiça (3. Turma). Recurso Especial 904.813/PR. Processo Civil. Recurso Especial. Licitação. Arbitragem. Vinculação ao edital. Cláusula de Foro. Compromisso Arbitral. Equilíbrio Econômico-Financeiro do contrato. Possibilidade. 
Recorrente: Companhia Paranaense de Gás Natural - COMPAGÁS. Recorrido: Consórcio Carioca Passarelli. Relator: Min. Nancy Andrighi, 20 de outubro de 2006. Disponível em: http://www.direitocom.com/wp-content/uploads/904813.pdf. Acesso em: 28 ago. 2019.

BRASIL. Superior Tribunal de Justiça (3. Turma). Recurso Especial 1.598.220/RN. Recurso Especial. Direito Civil e Processual Civil. Arbitragem. Cláusula Compromissória. Competência do Juízo Arbitral. Princípio Kompetenz-Kompetenz. Precedentes. Dissídio Notório. Recorrente: Sonangol Hidrocarbonetos Brasil Ltda. Recorrido: TPG Industria e Comercio Ltda - ME. Relator: Min. Paulo De Tarso Sanseverino, 25 de junho de 2019. Disponível em:

https://ww2.stj.jus.br/processo/revista/documento/mediado/?componente=ITA\&sequencial=1 $842478 \&$ num_registro=201601158240\&data=20190701\&formato=PDF. Acesso em: 30 ago. 2019.

BRASIL. Supremo Tribunal Federal (Tribunal pleno). Agravo de Instrumento 52.181/GB. Incorporação, bens e direitos das empresas Organização Lage e do Espólio de Henrique Lage. Juízo arbitral. Cláusula de irrecorribilidade. Juros da mora. Correção monetária. Agravante: União Federal. Agravados: Espólio de Henrique Lage e outros. Relator: Min. Bilac Pinto, 14 de novembro de 1973. Disponível em:

http://bibliotecadigital.fgv.br/ojs/index.php/rda/article/viewFile/40890/39650. Acesso em: 30 ago. 2019.

BRASIL. Supremo Tribunal Federal (Tribunal Pleno). Agravo Regimental na Sentença Estrangeira 5.206/DF. Sentença estrangeira. Laudo arbitral: homologação: Lei da Arbitragem: controle incidental de constitucionalidade e o papel do STF. Lei da Arbitragem (Lei n9.307/96). Agravante: MBV Commercial and export Management Establisment. Agravado: Resil Indústria e Comércio Ltda. Relator: Min. Sepúlveda Pertence, 12 de dezembro de 2001. Disponível em:

http://redir.stf.jus.br/paginadorpub/paginador.jsp?docTP=AC\&docID=345889. Acesso em: 28 ago. 2019.

CARMONA, Carlos Alberto. Arbitragem e administração pública - primeiras reflexões sobre a arbitragem envolvendo a administração pública. Revista Brasileira de Arbitragem, [s.1], ano XIII, n. 51, p. 7-21, jul./set. 2016.

CARMONA, Carlos Alberto. Em torno do árbitro. Revista de Arbitragem e Mediação RArb, v. 28, n. 47, jan. 2011. In: WALD, Arnold. Doutrinas Essenciais Arbitragem e Mediação, v. 2, p. 681-697, 2014.

CARMONA, Carlos Alberto. Superior Tribunal de Justiça, segurança jurídica e arbitragem. Revista de Arbitragem e Mediação - RArb, v. 34, n. 97, jul. 2012. In: WALD, Arnold.

Doutrinas Essenciais Arbitragem e Mediação, v. 1, p. 579-588, 2014.

CARVAlHO FILHO, José dos Santos. Manual de Direito Administrativo. 31. ed. São Paulo: Atlas, 2017.

CONSELHO NACIONAL DE JUSTIÇA (CNJ). Poder Judiciário. Departamento de Pesquisas Judiciárias. Justiça em números 2018: ano-base 2017. Brasília: CNJ, 2018. Disponível em: 
http://www.cnj.jus.br/files/conteudo/arquivo/2018/08/44b7368ec6f888b383f6c3de40c32167.p df. Acesso em: 01 abr. 2019.

DALLARI, Dalmo de Abreu. A tradição da arbitragem e sua valorização contemporânea. Revista de Arbitragem e Mediação - RArb, v. 35, n. 299, out. 2012. In: WALD, Arnold. Doutrinas Essenciais Arbitragem e Mediação, v. 1, p. 880-895, 2014.

DI PIETRO, Maria Sylvia Zanella. Direito Administrativo. 30. ed. Rio de Janeiro: Forense, 2017.

FIGUEIREDO, Leonardo Vizeu. Lições de Direito Econômico. 7 ed. Rio de Janeiro: Forense, 2014.

FONTES-FILHO, Joaquim Rubens. A governança corporativa em empresas estatais brasileiras frente a Lei de Responsabilidade das Estatais (Lei no 13.303/2016). Rev. Serv. Público Brasília 69, edição especial Repensando o Estado Brasileiro, p. 181-209, dez. 2018.

GIAMBIAGI, Fabio; ALÉM, Ana Cláudia Duarte de. Finanças públicas: teoria e prática no Brasil. 3. ed. Rio de Janeiro: Elsevier: Campus, 2008.

GRAU, Eros Roberto. Da arbitralidade de litígios envolvendo sociedades de economia mista e da interpretação de cláusula compromissória. Revista de Direito Bancário e do Mercado de Capitais - RDB, v. 18, n. 395, out. 2002. In: WALD, Arnold. Doutrinas Essenciais Arbitragem e Mediação, v. 4, 2014, p. 811-826.

GROSSI, Giuseppe; PAPENFUß, Ulf; TREMBLAY, Marie-Soleil. Corporate governance and accountability of State-Owned enterprises: relevance for science and society and interdisciplinary research perspectives. International Journal of Public Sector Management, [s.1.], v. 28, n. 4/5, p. 274-285, 2015.

IBGE - Instituto Brasileiro de Geografia e Estatística. Pesquisa de Inovação 2008. Rio de Janeiro: IBGE, 2010. Disponível em:

https://biblioteca.ibge.gov.br/visualizacao/livros/liv46495.pdf/. Acesso em: 28 ago. 2019.

KLIASS, Paulo. A configuração das empresas estatais federais: evolução de 2003 a 2017.

Boletim de Análise Político-Institucional, [s.1.], n. 15, p. 13-25, jul./dez. 2018.

MALHEIRO, Emerson Penha; BENATTO, Pedro Henrique Abreu. Arbitragem no Poder Público do Brasil. Direitos Fundamentais \& Justiça, Belo Horizonte, ano 11, n. 36, p. 131144, jan./jun. 2017.

MARCONI, Marina de Andrade. Metodologia Cientifica: para o curso de Direito. 2. ed. São Paulo: Atlas, 2001.

MAXIMIANO, Antônio Cesar Amaru; NOHARA, Irene Patrícia. Gestão Pública:

Abordagem integrada da Administração e do Direito Administrativo. São Paulo: Atlas, 2017.

OCTAVIANI, Alessandro; NOHARA, Irene Patrícia. Estatais. São Paulo: Thomson Reuters Brasil, 2019. 
PAULA, Fábio de Oliveira. Inovação nas Empresas Estatais Federais Brasileiras: fatores influentes e agenda para pesquisas futuras. Boletim de Análise Político-Institucional, [s.1.], n. 15, p. 115-121, jul./dez. 2018.

PUGLIESE, Antonio Celso Fonseca; SALAMA, Bruno Meyerhof. A economia da arbitragem: escolha racional e geração de valor. Revista de Direito GV, São Paulo, v. 4, n. 1, p. 15-28, jan./jun. 2008 .

SCAVONE JUNIOR, Luiz Antonio. Manual de arbitragem: mediação e conciliação. 8. ed. Rio de Janeiro: Forense, 2018.

SOMBRA, Thiago Luís. Mitos, crenças e a mudança de paradigma da arbitragem com a administração pública. Revista Brasileira de Arbitragem, [s.1.], v. XIV, n. 54, p. 54-72, 2017.

TALAMINI, Eduardo; FRANZONI, Diego. Arbitragem e empresas estatais. Interesse Público, Belo Horizonte, ano 19, n. 105, p. 15-45, set./out. 2017.

TIMM, Luciano Benetti; SILVA, Thiago Tavares da. Os contratos administrativos e a arbitragem. Revista Brasileira de Arbitragem, [s.1.],v. VIII, n. 29, p. 43-59, 2011.

ZAPPALÁ, Francesco. Memória histórica da arbitragem. Meritum, Belo Horizonte, v. 6, n. 1, p. 101-132, jan./jun. 2011. 


\title{
ASPECTOS JURÍDICOS DE COMPLIANCE E PROTEÇÃO AMBIENTAL
}

\author{
Legal aspects of compliance and environmental protection
}

\section{André Serotini}

\begin{abstract}
Doutor em Ciência Política pela Universidade Federal de São Carlos - PPGPOL/UFSCar (2014). Mestre em Desenvolvimento Regional e Meio Ambiente pelo Centro Universitário de Araraquara UNIARA (2005). Especialista em Direito Público, Educação Ambiental e Gestão Educacional. Professor de Direito Ambiental do Curso de Direito e do Programa de Mestrado em Ciências Ambientais da Universidade do Estado de Minas Gerais - UEMG - Unidade Frutal. Professor do Curso de Direito do Centro Universitário Central Paulista - UNICEP. Pesquisador do Núcleo de Estudos em Gestão e Impactos Ambientais - NEGIA, da UEMG - Frutal. Advogado e Consultor Jurídico com atuação em Direito Ambiental. E-mail: andre.serotini@uemg.br
\end{abstract}

Resumo: Em razão da entrada em vigência da lei que dispõe sobre a responsabilização administrativa e civil de pessoas jurídicas pela prática de atos contra a administração pública, nacional ou estrangeira, em agosto de 2013, popularmente denominada de Lei Anticorrupção (Lei 12.846/13), o instituto do compliance, já consolidado no sistema jurídico americano e europeu, ganhou relevância nacional, em especial para as organizações que mantém relação com a administração pública. Desta forma, este artigo tem como objetivo apresentar os principais aspectos jurídicos do compliance no Brasil, o considerando como importante instrumento de gestão ambiental, trazendo vantagens estratégicas para as organizações nacionais diminuindo riscos, aumentando a eficiência de processos produtivos e, colaborando, em última instância para a prevenção de riscos ao meio ambiente, desenhando, desta forma, o conceito de compliance ambiental. Adota-se para a realização desta pesquisa o método de abordagem teórica lógico-dedutivo, baseado no necessário levantamento bibliográfico partindo do referencial teórico apresentado por Coimbra e Manzi (2010).

Palavras-Chaves: Compliance ambiental; Gestão Ambiental; Conformidade Ambiental

\begin{abstract}
Due to the entry into force of the law that provides for administrative and civil liability of legal entities for acts against the national and foreign public administration, in August 2013, popularly called the Anti-Corruption Law (Law 12.846 / 13), compliance, already consolidated in the American and European legal systems, has become nationally relevant, especially for organizations that have a relationship with public administration. Thus, this article aims to present the main legal aspects of compliance in Brazil, considering it as an important instrument of environmental management, bringing strategic advantages to these national organizations, reducing risks, increasing the efficiency of production processes and ultimately collaborating with the prevention of risks to the environment, thus designing the concept of environmental compliance. For this research, the method of logical-deductive theoretical approach is adopted, based on the necessary bibliographical survey starting from the theoretical framework presented by Coimbra and Manzi (2010).
\end{abstract}

Keywords: Environmental Compliance; Environmental management; Environmental Conformity

\section{INTRODUÇÃO}


Nos últimos anos, principalmente após a sanção da Lei nº 12. 846/13 (Lei Anticorrupção), regulamentada pelo Decreto $\mathrm{n}^{\circ}$. 8.420/15, a palavra, em inglês, sem uma significação específica em língua portuguesa - compliance - tem aparecido nos meios empresariais com mais frequência. Isto se deve ao fato da lei retro mencionada dispor sobre a responsabilização administrativa e civil de pessoas jurídicas pelas práticas de atos contra a administração pública, sejam elas nacionais ou estrangeiras, dando ênfase a implantação de um programa de integridade, objetivando a criação de um conjunto de mecanismos e procedimentos internos de integridade, auditoria e incentivo à denúncia de irregularidades e, principalmente, para o caso em tela, de aplicação efetiva de código de ética e de conduta, políticas e diretrizes com objetivo de detectar e sanar desvios, fraudes, irregularidades e atos ilícitos praticados contra a administração pública. (BRASIL, 2015).

Alinhado à tais fundamentos e considerando a importância significativa da proteção do meio ambiente, juntamente com o crescimento econômico e a equidade social, pilares do desenvolvimento sustentável para o fortalecimento da sociedade contemporânea, entende-se o compliance como um importante instrumento para os processos gerenciais e de tomada de decisão das organizações, surgindo, desta forma, o termo compliance ambiental.

O objetivo deste trabalho é apresentar os principais aspectos que devem ser levados em consideração quando da adoção de um sistema de compliance ambiental, discorrendo sobre as principais vantagens percebidas pela empresa e para o meio ambiente.

Adota-se para a realização desta pesquisa o método de abordagem teórica lógicodedutivo, baseado no necessário levantamento bibliográfico partindo do referencial teórico apresentado por Coimbra e Manzi (2010), apontando que compliance é o deve de cumprir, de estar em conformidade com leis, diretrizes e regulamentos internos e externos, objetivando a mitigação de riscos à reputação, bem como riscos regulatórios e/ou legais. Ainda, de acordo com os autores mencionados, desta significação origina a expressão "risco de compliance", relacionada ao risco legal, sanções regulatórias, perda financeira ou perda de reputação, que uma organização pode estar sujeita quando do cometimento de falhas no cumprimento de leis, regulamentações, códigos de conduta e das boas práticas. (COIMBRA e MANZI, 2010); Andrade e Rossetti (2009), informando que compliance é considerado uma gestão corporativa da observância dos regulamentos internos e externos da atividade da empresa; e, Candeloro, De Rizzo e Pinho (2012), informando que o compliance possui, também, função de assistência à alta administração na sua responsabilidade de observar o arcabouço regulatório e as melhores práticas na execução das estratégias e dos processos decisórios. 
Para alcançar o propósito deste artigo estrutura-se o seu desenvolvimento numa parte primária reservada para tratar da origem e definição do compliance. Na sequência aborda-se os aspectos jurídicos-ambientais a serem considerados quando da instituição de compliance nas organizações e, ao finalizar, apresenta-se considerações sobre a possibilidade e eficácia da adoção de compliance como ferramenta de conformidade e proteção ambiental na área corporativa.

\section{DESENVOLVIMENTO}

Com a constitucionalização da tutela do meio ambiente no Brasil, no final da década de 1980, antecedida pela elaboração da Lei Federal 6.938/81, criando a Política Nacional do Meio Ambiente, vigente até os dias atuais, inserida num contexto de preocupação com a qualidade ambiental em âmbito global cujo início se dá na década de 1970, com a Conferência de Estocolmo, abrindo a chave do desenvolvimento sustentável, há uma mudança na cultura organizacional das empresas, as quais necessitaram adotar metodologias de produção menos poluentes e a utilização racional de recursos naturais.

Soma-se a este quadro, com o processo de globalização comercial, a busca, por parte do empresariado brasileiro de oportunidade de exportar seus produtos, se deparando com exigências, principalmente, pelos mercados americano e europeu, de cumprimento de requisitos, primeiramente relacionados à qualidade e, de adequação de aspectos ambientais, marcadas pelas Normas ISO 9.001 e 14.001, respectivamente.

No que tange aos aspectos ambientais, as empresas brasileiras iniciam importante processo de implantação de Sistemas de Gestão Ambiental - SGA, buscando sua adequação aos padrões internacionais, resultando na obtenção de selos e certificados de conformidade ambiental.

Inicialmente, as empresas foram motivadas por abertura de novos mercados, visando crescimento econômico, bem como da veiculação de marketing positivo, demonstrando uma preocupação que transcende a ideia de lucro. Posteriormente, estas entenderam que a conformidade de seus processos com as boas práticas empresariais como a governança e o atendimento à legislação ambiental, podiam resultar numa gestão estratégica voltada para a diminuição de riscos e de ganho de eficiência.

Neste sentido, ao conceituar compliance, segundo Coimbra e Manzi (2010), como o dever de cumprir, de estar em conformidade com leis, diretrizes e regulamentos internos e externos, objetivando a mitigação de riscos à reputação, bem como riscos regulatórios e/ou 
legais, percebe-se que há uma relação ou até mesmo uma complementaridade com o processo iniciado objetivando a certificação ambiental, todavia, mais complexo.

Ao analisar os argumentos acima e a constatação de que, mesmo com a necessidade de estar em conformidade com as normativas de sustentabilidade ambiental, é possível constatar a continuidade de ocorrências de lesões ao meio ambiente provocadas por grandes organizações, Isto, talvez, mostra que está faltando, por parte do setor produtivo nacional maiores investimentos na prevenção, acompanhamento e controle de suas atividades e, por parte do poder público, maior responsabilidade no seu processo fiscalizatório e punitivo.

O Conselho Administrativo de Defesa Econômica - CADE, vinculado ao Ministério da Justiça, publicou no ano de 2016, o Guia Programas de Compliance: Orientações sobre a estruturação e benefícios da adoção dos programas de compliance concorrencial, que além de tratar das questões relacionadas ao sistema concorrencial, traz importantes tópicos sobre os benefícios do programa de compliance para as organizações. (CADE, 2016).

Os programas de compliance abrangem ou podem abranger, de acordo com a finalidade de cada organização, áreas como; combate à corrupção, governança, fiscal, concorrencial, dentre outras, de forma independente ou agregada. Todavia, para o tratamento da temática proposta, o foco se restringe à área ambiental. E, por meio dos pontos apresentados no manual acima citado procura-se manter relação com os principais benefícios de adoção de um programa de compliance ambiental para as organizações.

Parte-se da premissa de que num programa de compliance, as organizações, bem como seus sócios e/ou colaboradores, assumem e reforçam o compromisso de estar em conformidade com os valores e objetivos da instituição e, principalmente, com a legislação vigente, prescindindo de uma mudança na cultura organizacional, unificando a comunicação interna com as condutas que possam ser externalizadas.

De forma geral, qualquer organização pode se beneficiar de um programa de compliance, todavia, os riscos variam de acordo com o porte da organização, sua posição de mercado, setor de atividades, objetivos, entre outros, características estas que tornam os programas de compliance distintos entre si. No que se refere aos riscos, o setor de atividades de uma organização, principalmente se nesta utiliza-se recursos naturais no seu processo produtivo ou se tal atividade possa trazer algum dano ao meio ambiente, é uma das principais justificativas para a adoção de um programa de compliance ambiental.

De acordo com CADE (2016), além das próprias empresas, investidores, consumidores e parceiros comerciais, também obtém benefícios com a adoção de programas de compliance, na medida em que previne a ocorrência de infrações e danos delas decorrente, 
evitando, desta forma, perda de valor para as empresas e, ao mesmo tempo, traz benefícios para a sociedade, vez que, no que tange a questão ambiental, a prevenção sempre será a melhor atitude a ser tomada.

Restritivamente às organizações, segundo dados apresentados pelo CADE (2016), os principais benefícios do programa de compliance são: 1. prevenção de riscos; 2. Identificação antecipada de problemas; 3 . Reconhecimento de ilicitude em outras organizações; 4 . benefício reputacional; 5. conscientização dos funcionários, e; 6. Redução de custos e contingências.

Desta forma, analisa-se na sequência o teor dos principais aspectos benéficos do programa:

\section{Prevenção de Riscos}

De acordo com o guia apresentado, a adoção de programas de compliance identifica, mitiga e remedia os riscos de violações da lei, logo de suas consequências adversas. (CADE, 2016).

Assim, é extremamente oportuno e razoável apresentar a prevenção de riscos como sendo o primeiro grande benefício do programa de compliance, vez que os principais princípios do direito ambiental são os da precaução e da prevenção, disciplinando que o objetivo da manutenção de um sistema de tutela ambiental é o de se evitar a ocorrência de danos e, apenas quando isto não for possível, necessária será a adoção de medidas mitigadoras e de reparação das lesões sofridas pelo meio ambiente.

Sabe-se que há uma vasta gama de atividades que utilizam recursos ambientais no seu processo produtivo, direta ou indiretamente, bem como há atividades cuja sua operação traz grandes impactos ao meio ambiente, como é o caso da mineração, todavia tais atividades são imprescindíveis para o desenvolvimento econômico e social do pais e, nestes casos, com muito mais veemência é que se faz necessária a adoção de mecanismos eficientes e eficazes de prevenção de riscos.

Sobre o princípio da prevenção, Antunes (2019) dispõe:

É princípio próximo ao da precaução, embora com este não se confunda. O princípio da prevenção aplica-se a impactos ambientais já conhecidos e dos quais se possa, com segurança, estabelecer um conjunto de nexos de causalidade que seja suficiente para a identificação dos impactos futuros mais prováveis. Com base no princípio da prevenção, o licenciamento ambiental e, até mesmo, os estudos de impacto ambiental podem ser realizados e são solicitados pelas autoridades públicas. Pois tanto o licenciamento quanto os estudos prévios de impacto ambiental são realizados com base em conhecimentos acumulados sobre o meio ambiente. O licenciamento 
ambiental, na qualidade de principal instrumento apto a prevenir danos ambientais, age de forma a evitar e, especialmente, minimizar e mitigar os danos que uma determinada atividade causaria ao meio ambiente, caso não fosse submetida ao licenciamento ambiental. (ANTUNES, 2019).

E, continua:

É importante deixar consignado que a prevenção de danos, tal como presente no princípio ora examinado, não significa - em absoluto - a eliminação de danos. A existência de danos ambientais originados por um empreendimento específico é avaliada em conjunto com os benefícios que são gerados pelo mencionado empreendimento e, a partir de uma análise balanceada de uns e outros, surge a opção política consubstanciada no deferimento ou indeferimento do licenciamento ambiental. As condicionantes estabelecidas para a implantação do projeto, de certa maneira, indicam as condições técnicas e políticas mediante as quais o administrador estabelece a ponderação entre os diferentes interesses em jogo. Este mecanismo de valoração é mais claramente definido na aplicação do chamado princípio do equilíbrio, que será examinado adiante. (ANTUNES, 2019).

Diante desta disposição, pode-se afirmar que a adoção do programa de compliance ambiental vem ao a encontro da possibilidade de se concretizar o contido no princípio da prevenção sediado no direito ambiental, tornando-se, importante ferramenta de proteção do meio ambiente e de controle de riscos das organizações.

\section{Identificação Antecipada de Problemas}

O guia traz que a conscientização promovida pelos programas de compliance acerca das condutas indesejadas permite a identificação de violações à lei mais rapidamente, favorecendo pronta resposta pela organização. (CADE, 2016).

Neste sentido, de acordo com Antunes (2019):

O princípio da precaução tem sido prestigiado pelo legislador brasileiro que, em muitas normas positivadas, determina uma série de medidas com vistas à avaliação dos impactos ambientais reais e potenciais gerados pelos diferentes empreendimentos. Ainda que extremamente relevante - o que é reconhecido por toda a doutrina brasileira e pelo nosso ordenamento jurídico -, o princípio da precaução não é dotado de normatividade capaz de fazer com que ele se sobreponha aos princípios da legalidade (um dos princípios setoriais reitores da administração pública) e, especialmente, aos princípios fundamentais da República, repita-se. A aplicação do princípio da precaução somente se justifica constitucionalmente quando observados os princípios fundamentais da República e ante a inexistência de norma capaz de determinar a adequada avaliação dos impactos ambientais. Fora de tais limites, a aplicação do princípio da precaução se degenera em simples arbítrio. (ANTUNES, 2019). 
Isto significa que o princípio da precaução não pode ser visto apenas como uma forma de impedir o desenvolvimento das atividades produtivas, mas propiciar que tais atividades sejam realizadas com seriedade, ética e conduzida por um senso de responsabilidade pelo meio ambiente, considerado um interesse difuso, necessário para a qualidade de vida.

\section{Reconhecimento de Ilicitudes em Outras Organizações}

Sobre o reconhecimento de ilicitudes em outras organizações, o guia informa que

a conscientização promovida pelos programas de compliance permite que os funcionários identifiquem sinais de que outras organizações, como concorrentes, fornecedores, distribuidores ou clientes, possam estar infringindo a lei. Essa identificação é relevante na medida em que relacionarse com terceiros que violam a legislação pode ser prejudicial para um agente econômico quando da análise das infrações, especialmente a depender de nível de envolvimento. (CADE, 2016).

E, continua:

Relacionamento estrito entre companhias sugere maior alinhamento de práticas comerciais. Nessa toada, é muito importante ser capaz de agir no caso de identificação de condutas ilícitas de terceiros com quem as trocas são intensas, para que não restem dúvidas sobre a boa-fé da companhia. (CADE, 2016).

De forma geral, pode-se relacionar a este indicador, a obediência ao princípio da responsabilidade e, sobre tal, Antunes (2019) dispõe o seguinte:

Qualquer violação do Direito implica a sanção do responsável pela quebra da ordem jurídica. A CF Brasileira estabelece, no § 30 do artigo 225, a responsabilidade por danos ao meio ambiente, embora não defina o caráter subjetivo ou objetivo dela. Esta questão restou delegada para a legislação ordinária que a definiu como objetiva. Um ponto que julgo mereça ser ressaltado é o fato de que a responsabilidade, no sistema jurídico brasileiro, decorre de lei, contrato ou ato ilícito. A responsabilidade ambiental se divide em: (i) civil, (ii) administrativa e (iii) penal. (ANTUNES, 2019).

\section{Benefício Reputacional}

A reputação de uma organização é um fator importante de estabilidade, neste sentido, o guia traz que as

Ações afirmativas de incentivo à conformidade com a lei são parte essencial de uma cultura de ética nos negócios, que resulta em benefício para a 
reputação da organização e sua atividade para fins promocionais, de recrutamento e de retenção de colaboradores. Essas ações tendem a aumentar a satisfação e o comprometimento no trabalho e o senso de pertencimento e identificação com o grupo. O comprometimento com a observância das leis também inspira confiança em investidores, parceiros comerciais, clientes e consumidores que valorizam organizações que operam de forma ética e que se sentiriam enganados em caso de infração. (CADE, 2016).

E, completa:

Violações à lei geram questionamentos sobre a ética e o modelo de negócios da entidade envolvida. O possível impacto econômico decorrente do dano à reputação - potencializado pela cobertura da mídia - pode ser ainda maior do que o resultante da pena pela infração, por levar a perdas não só financeiras, mas também de oportunidade de negócios. Organizações que tem programas de compliance instalados são cada dia mais atraentes como parceiros de negócios e como boas instituições para se trabalhar. (CADE, 2016).

\section{Conscientização dos Funcionários}

(...) programas de compliance bem elaborados e devidamente implementados permitem aos colaboradores tomar decisões com mais confiança. O medo de violar as leis - notadamente quando envolvido risco de persecução penal pode intimidar os colaboradores e eventualmente desestimular a concorrência mais acirrada e legítima. (CADE, 2016).

\section{Redução de Custos e Contingências}

A diminuição de custos é um excelente indicador de sustentabilidade financeira da organização e, neste sentido o guia apresenta que

A adoção de um programa de compliance pode evitar que as empresas incorram em custos e contingências com investigações, multas, publicidade negativa, interrupção das atividades, inexequibilidade dos contratos ou cláusulas ilegais, indenizações, impedimento de acesso a recursos públicos ou de participação em licitações públicas, etc. (CADE, 2016).

E, continua:

Além de despesas judiciais e administrativas, investigações requerem a alocação de recursos humanos e financeiros que de outra forma seriam empregados na atividade-fim da empresa. Ademais, adicionalmente ao processo administrativo, as empresas podem ter que responder civil e criminalmente pela infração cometida. (CADE, 2016).

E, termina: 
Danos à reputação podem ser sentidos antes mesmo do desfecho do processo, somente por estarem sob investigação, refletindo-se em perdas de clientes, oportunidades de negócios, investimento, valor de mercado, etc. (CADE, 2016).

Aproxima-se deste aspecto a conformidade com o princípio do poluidor-pagador, o qual segundo Antunes (2019).

parte da constatação de que os recursos ambientais são escassos e que o seu uso na produção e no consumo acarretam a sua redução e degradação. Ora, se o custo da redução dos recursos naturais não for considerado no sistema de preços, o mercado não será capaz de refletir a escassez. Assim sendo, são necessárias políticas públicas capazes de eliminar a falha de mercado, de forma a assegurar que os preços dos produtos reflitam os custos ambientais. (ANTUNES, 2019).

Antunes (2019), explica:

Os recursos ambientais são em geral limitados e o seu uso em atividades de produção e consumo pode levá-los à deterioração. Quando o custo desta deterioração não é adequadamente levado em conta no sistema de preços, o mercado falha em refletir a escassez de tais recursos no nível nacional e no internacional. Medidas públicas são, então, necessárias para reduzir a poluição e para alcançar uma melhor alocação de recursos, assegurando que os preços dos bens dependentes da qualidade e da quantidade de recursos ambientais reflitam mais proximamente a sua escassez relativa e que os agentes econômicos envolvidos ajam de acordo... (ANTUNES, 2019).

Após apresentar estes pontos retirados do guia do CADE (2016) e, de certa forma, relacioná-los com os principais princípios do direito ambiental, pode-se utilizar o posicionamento de Oliveira; Costa; Pinto e Silva (2018) para uma síntese de todo exposto:

Por intermédio do compliance, a pessoa jurídica cria internamente um conjunto de normas e procedimentos, com a finalidade de alcançar e manter maior grau, de conformidade com os sistemas normativos a que está sujeita em suas atividades, como os sistemas jurídico, ético e técnico-científico. Assim, a pessoa jurídica estabelece critérios substantivos e formais de prevenção, controle e responsabilização de práticas inadequadas e de potencial repercussão negativa interna e, sobretudo, externa. Nesse sentido, o compliance resulta em maior accountability e responsiveness da atividade empreendedora, o que, de alguma maneira, contribui para a sua higidez e eficiência funcional e finalística. (OLIVEIRA; COSTA; PINTO E SILVA, 2018)

E, aponta com principais benefícios que:

(...)a institucionalização de sistemas de compliance eleva a credibilidade estrutural, funcional e conjuntural da pessoa jurídica, fortalecendo sua higidez (vitalidade do empreendimento) e eficiência na produção de bens ou prestação de serviços. Logo, o instituto do compliance, em suas várias modalidades, atua 
como importante instrumento de precaução, avaliação, correção e revisão das políticas de gestão de empreendimentos privados e públicos. (OLIVEIRA; COSTA; PINTO E SILVA, 2018).

Por fim, Dias (2019) sustenta que existem fatores sociais e de conscientização, além, é claro, dos econômicos, que devem mover os empresários a adotarem programa de compliance ambiental, como apresentado a seguir:

Na nova concepção de empresa, esta compreende que a atividade econômica não deve orientar-se somente por uma lógica de resultados, mas também pelo significado que esta adquire na sociedade como um todo. Cada vez mais a empresa é compreendida menos como uma unidade de produção, e mais como uma organização. E, como tal, é um sistema social, formado por um conjunto de pessoas que para ela convergem para alcançar determinados fins. Nesta perspectiva, o grupo social que constitui a organização deverá ter uma liderança que deve estabelecer e firmar objetivos éticos para orientar suas atividades. Assim, os empresários estão se conscientizando de que a empresa não é somente uma unidade de produção e distribuição de bens e serviços que atendem a determinadas necessidades da sociedade, mas que deve atuar de acordo com uma responsabilidade social que se concretiza no respeito aos direitos humanos, na melhoria da qualidade de vida da comunidade e da sociedade mais geral e na preservação do meio ambiente natural. Do ponto de vista ambiental, a consciência ecológica empresarial tem sido motivada, em parte, pelas pressões contínuas do Poder Público, da opinião pública e dos consumidores, e em muitos casos pela possibilidade de melhorar sua imagem junto a determinados mercados, o que resulta num aumento de seus benefícios. De qualquer modo, como resultado dessa preocupação ambiental, associada com as exigências legais e éticas da sociedade, muitas empresas têm procurado gradativamente assumir maior responsabilidade ecológica, adotando um papel mais ativo. As atitudes que as empresas têm adotado são de dois tipos: as reativas e as proativas. As empresas reativas, num primeiro momento, negam-se a aceitar pressões ou reagem diante delas; quando não há outro caminho, assumem a causa ambiental procurando obter vantagens no processo de mudança a que são obrigadas. (DIAS, 2019).

\section{CONSIDERAÇÕES FINAIS}

Evidente que este artigo não tem o escopo de esgotar o tema sobre compliance ambiental. Exatamente, o contrário. Trata-se de apresentar um recorte contextual para abrir o diálogo e contribuição para o desenvolvimento de novos trabalhos que possam apresentar considerações a respeito deste novo instrumento que, aparentemente, até este momento apenas contribui para o desenvolvimento das organizações nacionais. Mostrou-se neste trabalho que existem inúmeras possibilidades de adotar um programa de compliance que mais se adequa a realidade de cada empresa, todavia, é imprescindível que este programa seja baseado em pilares de ética, legalidade de moralidade. Também está claro que a adoção de compliance ambiental traz excelentes resultados econômicos e sociais, vez que confere ampla possibilidade de 
antecipação de resultados para as empresas e, as medidas preventivas, no intuito de evitar impactos ambientais, reverte-se em ganhos expressivos ao meio ambiente.

\section{REFERÊNCIAS}

AMADO, Frederico Augusto Di Trindade. Direito ambiental esquematizado. $5^{\text {a }}$ Edição. São Paulo: Método, 2014.

ANDRADE, Adriana; ROSETTI, José Paschoal. Governança Corporativa. Fundamentos, desenvolvimentos e tendências. $4^{a}$ Edição. Atualizada e ampliada. São Paulo: Atlas, 2009

ANTUNES, Paulo de Bessa. Direito Ambiental. 20. ed. São Paulo: Atlas, 2019.

BRASIL. Constituição da República Federativa do Brasil. Brasília, 1988. Disponível em: < http://www.planalto.gov.br/ccivil_03/constituicao/constituicaocompilado.htm> Acesso em: 06 set. 2018.

Lei Ordinária $n^{\circ} .6 .938$, de 31 de agosto de 1981. Dispõe sobre a Política Nacional do Meio Ambiente, seus fins e mecanismos de formulação e aplicação, e dá outras providências. Diário Oficial da União, Brasília, 2 set. 1981.

Lei Ordinária $n^{\circ} .12 .846$, de $1^{\circ}$ de agosto de 2013. Dispõe sobre a responsabilização administrativa e civil de pessoas jurídicas pela prática de atos contra a administração pública, nacional ou estrangeira, e dá outras providências. Diário Oficial da União, Brasília, 2 ago. 2013.

Decreto $n^{\circ}$. 8.420, de 18 de março de 2015. Regulamenta a Lei $\mathrm{n}^{\circ} .12 .846$, de $1^{\circ}$ de agosto de 2013, que dispõe sobre a responsabilização administrativa de pessoas jurídicas pela prática de atos contra a administração pública nacional ou estrangeira e dá outras providências. Diário Oficial da União, 19 mar. 2015.

CADE. Guia Programas de Compliance. Orientações sobre estruturação e benefícios da adoção dos programas de compliance concorrencial. Conselho Administrativo de Defesa Econômica - CADE. Brasília, 2016. Disponível em: http://www.cade.gov.br/acesso-ainformacao/publicacoes-institucionais/guias_do_Cade/guia-compliance-versaooficial.pdf/view, acesso em 03 jul. 2019.

COIMBRA, Marcelo de Aguiar; MANZI, Vanessa A. Manual de Compliance. Preservando a Boa Governança e a Integridade das Organizações. São Paulo: Atlas, 2010.

DIAS, Reinaldo. Gestão ambiental: responsabilidade social e sustentabilidade. 3. ed. São Paulo: Atlas, 2019.

DUNKLEY, Patrick H. College and University Compliance Programs: Overview goals, elements, structures and strategies. Stanford University, California, 2009. Disponível em: http://www.higheredcompliance.org/compliance/resources/xv-09-11-17.pdf, Acesso em: 22 jul. 2016. 
MACHADO, Paulo Affonso Leme. Direito ambiental brasileiro. 25 ed. rev., ampl., e atual. São Paulo: Malheiros, 2017.

OLIVEIRA, Marcio Luis; COSTA, Beatriz Souza; PINTO E SILVA, Cristiana Maria Fortini. $O$ instituto do compliance ambiental no contexto da sociedade plurissistêmica. Veredas do Direito, Belo Horizonte, v. 15, n. 33, p. 51-71, set./ dez. 2018. Disponível em: <http://www.domhelder.edu.br/revista/ index.php/veredas/article/view/1396>. Acesso em: 10 ago.2019.

PARKER, Craig W. College and University Compliance Programs: Obligations, organization and implementation. NACUA Conference, 2009. Disponível em: http://www.higheredcompliance.org/compliance/resources/xv-09-11-19.pdf, Acesso em: 22 jul. 2016.

RIBEIRO, M. C. P.; DINIZ, P. D. F. Compliance e Lei Anticorrupção nas Empresas. In Revista de Informação Legislativa, ano 52, número 205, jan./mar. 2015. Disponível em: https://www2.senado.leg.br/bdsf/bitstream/handle/id/509944/001032816.pdf?sequence=1, Acesso em: 22 jul. 2016.

ROACH, Robert F. Compliance at Larger Institutions. 2009. Disponível em: http://www.higheredcompliance.org/compliance/resources/larger-institutions.pdf, Acesso em: 22 jul. 2016.

SILVA, Daniel Cavalcante. Compliance como boa prática de gestão de ensino superior privado. Daniel Cavalcante Silva e José Roberto Covac. São Paulo, Saraiva, 2015.

SILVA, Romeu Faria Thomé da. Manual de direito ambiental. $7^{a}$ ed., rev., atual., e ampl. Salvador: JusPODIVM, 2017. 


\title{
A POSSIBILIDADE DE ACUMULAÇÃO DE CARGOS PÚBLICOS NO BRASIL SOB A ÓTICA CONSTITUCIONAL E ADMINISTRATIVA
}

\author{
The possibility of public offices accumulation in Brazil from constitutional and administrative \\ perspective
}

Danilo Vieira Vilela

\begin{abstract}
Professor efetivo da Universidade do Estado de Minas Gerais (UEMG). Doutor em Direito Político e Econômico pela Universidade Presbiteriana Mackenzie (Bolsista Mackenzie). Mestre em Direito Obrigacional Público e Privado pela Universidade Estadual Paulista Júlio de Mesquita Filho UNESP (Bolsista FAPESP), Especialista em Direito Processual (UEMG), Especialista em Direito Penal e Processual Penal (UCDB), Especialista em Direito Empresarial e Advocacia Empresarial (Anhanguera-Uniderp) e MBA em Gestão Empresarial (UNESC). Professor em cursos de pósgraduação e em cursos preparatórios para concursos. Advogado e Árbitro no CBLE - Centro Brasileiro de Litígios Econômicos. E-mail: danilo.vilela@uemg.br
\end{abstract}

\section{Giovanna Chaves Leal}

Pesquisadora bolsista em Iniciação Científica pelo Programa Institucional de Apoio à Pesquisa PAPq/UEMG (2018 e 2019). Graduação em Direito em andamento pela Universidade do Estado de Minas Gerais - UEMG/Frutal. Diretora da Gestão 2018 do departamento de Gestão de Pessoas da Avance Consultoria Júnior. Interessa-se por temas do Direito Administrativo, Direito Constitucional e Direitos Humanos. E-mail: gih.chaves@ hotmail.com

Resumo: O presente artigo busca discutir acerca da possibilidade de acumulação de cargos públicos no Brasil, uma vez que a Constituição da República de 1988 trata do assunto de forma expressa, proibindo tal acumulação, com apenas algumas exceções. Ao autorizar a acumulação de cargos públicos para alguns casos específicos, o texto constitucional não coloca nenhuma limitação em relação à carga horária, sendo a compatibilidade de horários a única condição expressa, provocando algumas discussões e demandas no Judiciário a respeito do assunto. Além disso, a lacuna existente no dispositivo constitucional em questão pode gerar um impacto negativo no princípio da eficiência, uma vez que todos os servidores públicos devem dispor de tempo para o devido descanso entre uma jornada e outra de trabalho para que, por fim, possa realizar com eficácia o seu labor, sem prejudicar o andamento dos serviços públicos e alcançando a maior eficiência na Administração Pública. Dessa forma, faz-se necessário o estudo detalhado da temática em questão e, principalmente, de decisões em que pesem o assunto para que seja possível formular um entendimento melhor a respeito do texto constitucional e seus desdobramentos na seara constitucional e administrativa. Além disso, busca-se analisar uma decisão do Superior Tribunal de Justiça, a qual trata de um recurso especial cuja discussão é a possibilidade de acumulação de dois cargos públicos por uma profissional de saúde.

Palavras-chave: Cargos públicos. Princípio da Eficiência. Administração Pública. Servidores públicos.

Abstract: This article seeks to discuss the possibility of public offices accumulation in Brazil, since the Constitution of the Republic of 1988 clearly provides on this matter, prohibiting such accumulation, with only a few exceptions. By authorizing the accumulation of public offices in some specific cases, the constitutional text does not restrict the workload in any way, once the schedule compatibility is the only expressed condition, which causes some discussions and demands in the judiciary system about this matter. Besides, the loophole in the law may lead to 
a negative impact on the principle of efficiency, as all public service employees must have enough time to rest between both workloads, so that they can perform their activity effectively, without promising the public services and achieving greater efficiency in Public Administration. Thus, it is necessary to study this matter and, especially, judicial decisions that provide for that as well, so that it's possible to formulate a better understanding about the constitutional text and its developments in the constitutional and administrative area. In addition to that, we seek to analyze a judicial decision from the brazilian Supreme Court, that provides for a special appeal, whose discussion is the possibility of the accumulation of two public positions by a health professional.

Key words: Public offices. Efficiency Principle. Public administration. Public employee.

\section{INTRODUÇÃO}

A presente pesquisa tem por objetivo traçar uma discussão acerca do instituto constitucional que autoriza a acumulação de cargos públicos em alguns casos específicos, desde que haja compatibilidade de horários, conforme disposto no artigo 37, inciso XVI da Constituição da República Federativa do Brasil (CRFB), de 1988. Nesse aspecto, busca-se analisar a jurisprudência do Superior Tribunal de Justiça a partir do Recurso Especial $\mathrm{n}^{\circ}$ 1.746.784/PE, interposto por autora impedida de assumir um cargo público em decorrência de já estar ocupando um outro cargo público, ambos na área de saúde. O impedimento alegado para o caso em questão foi em razão do Parecer Administrativo n ${ }^{\circ}$ GQ-145 da Advocacia Geral da União (AGU), o qual tenta limitar a acumulação de cargos públicos em 60 horas semanais. No entanto, a Constituição Federal permite a acumulação de cargos públicos de profissionais da área de saúde, bem como de professores, ou de professor e técnico/científico, cumulativamente, sendo a compatibilidade de horários o único requisito expresso no texto constitucional. Dessa forma, discutir-se-á a validade do parecer administrativo no julgamento do Recurso Especial supracitado, bem como as consequências das recentes alterações feitas pela Advocacia Geral da União (AGU), a qual revogou o parecer administrativo que limitava em 60 horas semanais a acumulação de cargos públicos.

Insta salientar que o dispositivo constitucional em questão não faz nenhuma limitação em relação à carga horária dos cargos acumulados, sendo a compatibilidade de horários a única restrição explícita. Dessa forma, faz-se necessária a observação do princípio da eficiência frente aos serviços prestados pelos agentes públicos, uma vez que é de fundamental importância, além da compatibilidade de horários, que os empregados públicos atuem com extrema qualidade para que os serviços públicos estejam sempre de acordo com tal princípio, bem como que os funcionários disponham de tempo suficiente para o descanso, com o intuito de obedecer demais 
normas constitucionais, além das normas de direito trabalhista. Além disso, é imprescindível a observação de outros dispositivos legais infraconstitucionais para que seja possível a delimitação da carga horária semanal máxima e que a qualidade do serviço seja boa e compatível com o principal objetivo da Administração Pública, qual seja, atender ao interesse público primário.

O trabalho aqui apresentado faz uso da pesquisa científica, assim conceituada por Flávio Tartuce: "a ciência é um procedimento metódico cujo objetivo é conhecer, interpretar e intervir na realidade, tendo como diretriz problemas formulados que sustentam regras e ações adequadas à constituição do conhecimento" (TARTUCE, 2006, p. 12 apud GERHARDT; SILVEIRA, 2009, p. 25). Nesse sentido, o estudo se deu através do método dedutivo, pois partiu-se da premissa de que a acumulação de cargos públicos, se não fiscalizada e realizada de maneira eficaz, pode intervir na efetividade do princípio da eficiência e causar prejuízos tanto ao servidor público quanto à sociedade. E ainda, como procedimento metodológico, foi utilizada a pesquisa bibliográfica e qualitativa.

\section{CARGO PÚBLICO E O PRINCÍPIO DA EFICIÊNCIA}

A Administração Pública tem seu funcionamento respaldado por servidores públicos dos mais diferentes cargos e desenvolve-se a partir das atividades exercidas por esses servidores, os quais são pessoas físicas que ocupam os cargos públicos. A priori é importante destacar a definição de cargo público, que está inserida no artigo $3^{\circ}$ da Lei no 8.112 de 1990, assim estabelecendo:

Art. $3^{\circ}$. Cargo público é o conjunto de atribuições e responsabilidades previstas na estrutura organizacional que devem ser cometidas a um servidor. Parágrafo único. Os cargos públicos, acessíveis a todos os brasileiros, são criados por lei, com denominação própria e vencimento pago pelos cofres públicos, para provimento em caráter efetivo ou em comissão. (BRASIL, 1990)

Assim, cargo público pode ser definido como um local instituído na organização do serviço público, com denominação própria, atribuições específicas e delimitadas e deve ser exercido, via de regra, por um titular, na forma em que a lei estabelecer. De forma sucinta, os cargos públicos são o instrumento pelo qual os servidores públicos manifestam a vontade do Estado e exercem as tarefas da Administração Pública que lhe são dadas, conforme prévia caracterização legal. Nesse sentido, o servidor público deve agir conforme estipulado na legislação específica e obedecer a todos princípios da Administração Pública para que esta funcione corretamente. Tais princípios são essenciais ao bom funcionamento da máquina 
pública de governo e são elencados no artigo 37 da Constituição Federal de 1988, quais sejam: princípio da legalidade, princípio da impessoalidade, princípio da moralidade, princípio da publicidade e o princípio da eficiência, sendo este último extremamente importante para a garantia da qualidade do serviço prestado pelos agentes públicos.

O princípio da eficiência é um importante instrumento para a garantia da qualidade dos produtos e serviços oriundos do Estado, pois impõe que o Estado e todos os seus agentes públicos realizem todas as suas atribuições com rapidez, perfeição e rendimento, buscando trazer para o meio administrativo qualidade e bons resultados. Sob a ótica de Hely Lopes Meirelles, a definição do princípio da eficiência se dá da seguinte forma:

O que se impõe a todo o agente público de realizar suas atribuições com presteza, perfeição e rendimento profissional. É o mais moderno princípio da função administrativa, que já não se contenta em ser desempenhada apenas com legalidade, exigindo resultados positivos para o serviço público e satisfatório atendimento das necessidades da comunidade e de seus membros. (MEIRELLES, 2003, p. 102)

O princípio da eficiência foi incluído no ordenamento jurídico brasileiro com a promulgação da Emenda Constitucional n 19, de 04 de junho de 1998, alterando o artigo 37 da Constituição da República de 1988. Insta salientar que esse princípio não possui um valor substancial de autossuficiência, nem tampouco pode sobrepor-se a qualquer outro princípio administrativo ou constitucional. No entanto, ele deve estar submetido ao princípio da legalidade, uma vez que toda e qualquer ação da Administração Pública, bem como de seus servidores, não pode contrariar o ordenamento jurídico, ou seja, independentemente do quão eficiente seja qualquer servidor público, ele deve obedecer todos os princípios constitucionais inerentes à Administração Pública e, principalmente, aos princípios da eficiência e legalidade de forma conjunta e integrada. Nesse aspecto, Maria Sylvia Zanella Di Pietro (2018, p. 152) dispõe que "a efíciência é princípio que se soma aos demais princípios impostos à Administração, não podendo sobrepor-se a nenhum deles, especialmente ao da legalidade, sob pena de sérios riscos à segurança jurídica e ao próprio Estado de direito".

Dessa forma, tal princípio abrange tanto a Administração Pública quanto o servidor público, pois ambos devem atuar com o objetivo de tornar o aparelho estatal menos burocrático e atender às necessidades da coletividade. Conforme ensinamentos da mesma professora supracitada, o princípio da eficiência ainda se apresenta sob dois aspectos:

[...] pode ser considerado em relação ao modo de atuação do agente público, do qual se espera o melhor desempenho possível de suas atribuições, para lograr os melhores resultados; e em relação ao modo de organizar, estruturar, disciplinar a Administração Pública, também com o mesmo objetivo de 
alcançar os melhores resultados na prestação do serviço público. (DI PIETRO, 2018, p. 151)

Portanto, o servidor público precisa dispor de tempo hábil e disponibilidade para que possa, de fato, cumprir sua função com responsabilidade e efetividade. Não obstante, deve ser observado também o princípio da razoabilidade, pois mesmo não sendo um princípio disposto de forma explícita na Constituição da República, ele deve ser observado pela Administração Pública e imposto a todos os seus agentes. Dito isto, não pode ser considerado razoável que uma pessoa trabalhe de forma exaustiva, seja em relação à qualidade e quantidade de trabalho a ela designado ou ao tempo de trabalho exercido, a ponto de comprometer o seu desempenho.

Daí a discussão acerca da possibilidade de acumulação de cargos públicos, bem como da carga horária máxima permitida.

\section{A ACUMUlaçÃo de CARgo PÚBlico NO TEXTO CONSTITUCIONAL E SEUS DESDOBRAMENTOS}

A acumulação de cargos públicos é tratada como excepcionalidade há décadas no Brasil. No entanto, com o advento da Constituição de 1934, algumas exceções foram feitas no que tange à tal possibilidade, ficando expressa a permissão para a acumulação de cargos públicos para os cargos do magistério e de técnico-científicos, desde que houvesse a compatibilidade de horários de serviços. Desde então, todas as demais Constituições brasileiras transcreveram o dispositivo constitucional em questão, permitindo a possibilidade de acumulação de cargos públicos nestes casos específicos, desde que não prejudique as respectivas jornadas de trabalhos, ou seja, com a devida compatibilidade de horários entre os cargos acumulados.

A Constituição Federal de 1988 estabelece regras a respeito da acumulação de cargos públicos, dispostas em seu artigo 37, inciso XVI da seguinte forma:

Art. 37. A administração pública direta e indireta de qualquer dos Poderes da União, dos Estados, do Distrito Federal e dos Municípios obedecerá aos princípios de legalidade, impessoalidade, moralidade, publicidade e eficiência e, também, ao seguinte:

XVI - é vedada a acumulação remunerada de cargos públicos, exceto, quando houver compatibilidade de horários, observado em qualquer caso o disposto no inciso XI:

a) a de dois cargos de professor

b) a de um cargo de professor com outro técnico ou científico;

c) a de dois cargos ou empregos privativos de profissionais de saúde, com profissões regulamentadas; (BRASIL, 1988)

Trata-se, portanto, de uma norma de eficácia plena, ficando explícito no texto que o único requisito para a acumulação remunerada de cargos públicos, nos casos acima citados, seja 
a compatibilidade de horários entre os cargos a serem ocupados. Ademais, o texto dispõe tão somente à acumulação remunerada de cargos públicos, podendo gerar uma possível confusão no que tange ao acúmulo de cargos sem remuneração. Porém, o artigo $4^{\circ}$ da lei 8.112/1990 proíbe a prestação de serviços gratuitos, salvo os casos previstos em lei, complementando o dispositivo constitucional em questão, fazendo com que não seja possível interpretação diversa à de que, em regra, não é permitido a acumulação de cargos públicos, seja ele remunerado ou não, com exceção dos casos dispostos na legislação. Vale ressalvar que essa vedação abrange os três Poderes de União (Legislativo, Executivo e Judiciário).

Não obstante, no dia 04 de julho de 2019 foi publicada a emenda constitucional $\mathrm{n}^{\mathrm{o}}$ 101/2019, a qual acrescenta o parágrafo $3^{\circ}$ ao art. 42 da CRFB para estender a possibilidade da acumulação de cargos públicos, prevista no art. 37, inciso XVI da mesma, aos militares dos Estados, do Distrito Federal e dos Territórios. Tal emenda se apresenta da seguinte forma:

As Mesas da Câmara dos Deputados e do Senado Federal, nos termos do $\S 3^{\circ}$ do art. 60 da Constituição Federal, promulgam a seguinte Emenda ao texto constitucional:

Art. $1^{\circ} \mathrm{O}$ art. 42 da Constituição Federal passa a vigorar acrescido do seguinte $\S 3^{\circ}$ :

"Art. 42.

$\S 3^{\circ}$ Aplica-se aos militares dos Estados, do Distrito Federal e dos Territórios o disposto no art. 37, inciso XVI, com prevalência da atividade militar." (BRASIL, 2019)

No entanto, em 1998 a Advocacia Geral da União publicou o Parecer Administrativo n ${ }^{\circ}$ GQ-145 que tenta limitar a acumulação de cargos públicos em 60 horas semanais, indo de oposto à única regra imposta no texto constitucional a respeito da acumulação e, em razão deste entendimento, muitos órgãos da Administração Pública Federal têm negado o direito ao servidor público de acumular dois cargos públicos, mesmo nos casos permitidos pela Constituição. Esse Parecer tinha como um de seus objetivos suprir a falta de previsão legal a respeito da carga horária máxima permitida para o acúmulo dos cargos públicos mencionados no texto constitucional, além de fazer uma breve analogia às regras de descanso previstas na Consolidação das Leis do Trabalho (CLT), pois a mesma prevê um descanso mínimo por dia de 11 horas interjornadas para o trabalhador, além dos demais intervalos intrajornadas que devem ser somados ao tempo de descanso para que o trabalhador possa dispor de saúde em boas condições para o exercício de seus ofícios, bem como de tempo para o devido repouso diário.

Este é o caso tratado no Recurso Especial no 1.746 .784 - PE, julgado em 23 de agosto de 2018. Neste, a autora ocupava o cargo de técnica em enfermagem na Secretaria do Estado 
do Pernambuco, com carga horária de trinta horas semanais e foi aprovada em outro concurso público para exercer a mesma função, cuja carga horária é de trinta e seis horas semanais. No entanto, com base no Parecer $n^{\circ}$ GQ-145 da AGU e no princípio da razoabilidade, uma vez que considerou ser razoável a limitação da carga horária semanal, foi impedida pela empresa de serviços hospitalares de ocupar o cargo em questão, daí a necessidade do recurso especial tendo como autora a servidora pública. O recurso especial ora analisado foi provido pelo Superior Tribunal de Justiça (STJ), com a justificativa de que a Constituição Federal não elenca nenhuma regra a respeito da carga horária, sendo a compatibilidade de horários o único requisito para a acumulação de cargos públicos. Além disso, cabe à Administração Pública aferir o cumprimento de tal requisito, devendo interpretar de maneira extensiva cada caso concreto, sempre levando em consideração os princípios constitucionais, em principal aos princípios da eficiência e da razoabilidade.

É importante ressaltar que o Supremo Tribunal Federal (STF) posiciona-se contrário ao Parecer GQ-145 da AGU, deixando claro que o dispositivo constitucional que trata da acumulação de cargos públicos não faz nenhuma menção à carga horária e, em razão disso, não devendo ser imposta nenhuma limitação de carga horária nesse sentido, conforme pode-se verificar em sua jurisprudência:

[...] no sentido de que a acumulação de cargos públicos de profissionais da área de saúde, prevista no art. 37, XVI, da CF/88, não se sujeita ao limite de 60 horas semanais previsto em norma infraconstitucional, pois inexiste tal requisito na Constituição Federal. (RE 1.094.802 AgR, Relator Min. Alexandre de Moraes, Primeira Turma, julgado em 11/5/2018, DJe $24 / 5 / 2018$ )

Nesse sentido, o entendimento da Suprema Corte é favorável à possibilidade de acúmulo de cargos públicos nos casos permitidos no texto constitucional, sem que haja a limitação de carga horária, havendo, portanto, um descaso na observância dos princípios administrativos da eficiência e da razoabilidade.

Já o Tribunal de Contas da União (TCU), que antes não reconhecia a limitação de carga horária relativa ao Parecer GQ-145 da AGU, passou a manifestar-se de forma contrária ao STF e favorável à AGU, como pode ser verificado em julgados mais recentes que disciplinam a mesma matéria em questão.

O STJ também vem mudando o seu entendimento a respeito do assunto, pois antes prevalecia o entendimento contrário ao Parecer QG-145, mas atualmente compreende que a acumulação de cargos deve ser interpretada de forma restritiva, com o objetivo de atender ao princípio constitucional da eficiência, ou seja, o entendimento atual é favorável à limitação de 
carga horária nos casos de possibilidade de acumulação de cargos públicos. Tal entendimento fica claro ao se analisar o voto do ministro Og Fernandes, relator do REsp acima analisado, disposto da seguinte forma:

O presente recurso merece prosperar. A Primeira Seção desta Corte Superior tem conhecido a impossibilidade da acumulação remunerada de cargos ou empregos públicos privativos de profissionais da área de saúde quando a jornada de trabalho for superior a 60 horas semanais. Estabeleceu-se que, apesar de a Constituição Federal permitir o exercício de atividades compatíveis em questão de horário, deve o servidor gozar de boas condições física e mentais para o desempenho de suas atribuições, em observância ao princípio administrativo da eficiência. (REsp 1.746.784 Relator Min. Og Fernandes, Segunda Turma, julgado em 23/8/2018, DJe 30/8/2018)

Ademais, o STF autorizou ainda, em 2017, a acumulação de salários acima do teto remuneratório do serviço público quando a pessoa tem mais de dois empregos públicos. Agora, nos casos de Juízes, integrantes do Ministério Público e ocupantes de cargo técnico ou científico que dão aula em instituição de ensino; professores com dois empregos; e profissionais de saúde também com dois empregos, há a possibilidade de se ultrapassar o teto constitucional dos servidores públicos, sendo este o valor recebido pelos ministros do $\mathrm{STF}$ ( $\mathrm{R} \$ 33.763,00$ em 2019). Os ministros seguiram decisão do Supremo Tribunal Federal de que o teto deve valer para cada um dos empregos isoladamente, e não pela soma total. Tal decisão pode gerar impactos negativos nos cofres públicos no que tange ao sistema previdenciário, caso o valor recebido durante tempo integral trabalhado também seja levado em consideração quando o servidor for se aposentar e gozar dos benefícios previdenciários, uma vez que o teto constitucional tem por principal objetivo manter o equilíbrio financeiro do Estado no que tange à remuneração dos agentes públicos, sendo essa decisão um possível passo para que tal regra constitucional venha a desaparecer futuramente.

Apesar de todos os conflitos existentes no âmbito do Direito Administrativo e Constitucional até abril de 2019, a tese firmada pela Advocacia Geral da União é a de revogação e pedido de revisão do Parecer GQ 145. O caso analisado era a respeito da acumulação de dois cargos públicos com carga horária de 40 horas semanais cada um e a conclusão foi de que é ilícita a acumulação de cargos públicos com carga horária total de 80 horas, levando em consideração a dificuldade de se harmonizar os horários e, ainda, de se observar os princípios constitucionais inerentes à Administração Pública e aos agentes públicos, e de que é lícita a acumulação de cargos públicos de 60 horas, desde que comprovada a compatibilidade de horários entre os dois e a ausência de prejuízo das atividades exercidas em ambos os empregos. 
Contudo, a Administração Pública deve exercer o seu papel no exercício do poder disciplinar e evitar que a falta de legislação complementar a respeito do limite da carga horária dos servidores públicos prejudique o bom funcionamento dos serviços públicos prestados. Cabe, portanto, ao poder público verificar os casos concretos de acumulação de cargos públicos e fiscalizar seus agentes públicos, verificando a eficiência de suas atribuições. Além disso, o Supremo Tribunal Federal deve trabalhar com maior ênfase para que suas decisões não alterem significativamente algumas questões constitucionais a fim de evitar o conflito de normas, bem como não ultrapassar os próprios limites estabelecidos no texto constitucional, como no caso do teto salarial, por exemplo. Por fim, é importante ressaltar a necessidade da uniformização da jurisprudência nas cortes superiores, principalmente no caso em questão, pois em regra a acumulação é nociva à sociedade, uma vez que cargos acumulados podem resultar em funções mal desempenhadas.

\section{CONCLUSÃO}

É inegável que a Constituição Federal da República deve ser regra de superior hierarquia, não podendo nenhum outro dispositivo infraconstitucional ir de encontro a ela. No entanto, ao observar o dispositivo aqui analisado, não se pode admitir que seja inconstitucional a limitação da carga horária dos servidores públicos, uma vez que o texto constitucional não menciona nenhuma regra a respeito da carga horária, e sim somente a respeito da possibilidade da acumulação de cargos públicos. Dessa forma, é perfeitamente possível que legislações infraconstitucionais possam tratar da limitação da carga horária dos servidores públicos, complementando o dispositivo aqui analisado com o objetivo de preencher lacunas existentes no ordenamento a respeito do assunto.

Além disso, é de suma importância verificar a efetividade dos princípios da eficiência e da razoabilidade, uma vez que o ser humano precisa de um intervalo de descanso suficiente para o devido repouso, para sua alimentação e locomoção em segurança e para todas suas necessidades básicas, pois a ausência destes pode causar danos aos servidores públicos e aos serviços por eles prestados. Ademais, não pode ser considerado razoável que uma pessoa trabalhe tanto a ponto de comprometer suas atividades laborais, podendo ser considerado um atropelamento nas regras de descanso previstas na CLT e na Constituição da República de 1988. Portanto, não basta apenas a compatibilidade de horários para a possibilidade da acumulação de cargos públicos, mas outros requisitos também devem ser observados para que o servidor esteja sempre em boas condições para a prestação do serviço ao qual foi designado em sua função enquanto servidor público. 
Não obstante, outra questão problemática é a autorização do Supremo Tribunal Federal em relação ao teto remuneratório nos casos de acumulação de cargos públicos, o que acaba por ferir o dispositivo constitucional que estipula o teto constitucional, qual seja, o salário dos ministros do STF, além da possibilidade de afetar ainda o sistema previdenciário, pois a aposentadoria dos servidores públicos que gozam de cargos acumulados deverá ser de acordo com seus novos salários. Como o objetivo principal do teto remuneratório constitucional é impedir abusos e ilegalidades, tal autorização pode dar abertura para que novas decisões no mesmo sentido sejam proferidas, fazendo com que a regra constitucional do teto salarial seja colocada em desuso com o passar do tempo, meio a tantos abusos advindos dos agentes públicos.

A verdade é que a compatibilidade de horários deve ser analisada de forma concreta e, caso constatada alguma deficiência no desempenho das atribuições funcionais do servidor público, a Administração Pública deve sim limitar a acumulação de cargos públicos, fazendo com que a qualidade seja prioridade, obedecendo ao princípio administrativo da eficiência e, por fim, cumprindo efetivamente o papel da administração de atender aos interesses sociais. É de suma importância que a máquina pública limite a acumulação de cargos públicos para que todos os aspectos do princípio da eficiência sejam, de fato, atendidos. Conclui-se, portanto, que o entendimento atual do Superior Tribunal de Justiça e do Tribunal de Contas da União, ambos favoráveis à limitação de carga horária, é o que melhor representa a atuação dos princípios da eficiência e da razoabilidade, devendo ser este o entendimento cabível em todos os casos de possibilidade de acumulação de cargos públicos.

\section{REFERÊNCIAS}

BRASIL. Constituição da República Federativa do Brasil de 1988. Disponível em: http://www.planalto.gov.br/ccivil_03/Constituicao/Constituicao.htm. Acesso em: 09 set. 2019.

BRASIL. Constituição da República Federativa do Brasil de 1934. Disponível em: http://www.planalto.gov.br/ccivil_03/constituicao/constituicao34.htm. Acesso em: 09 set. 2019.

BRASIL. Emenda Constitucional $\mathbf{n}^{\mathbf{0}} 101$, de 3 de julho de 2019. Acrescenta $\S 3^{\circ}$ ao art. 42 da Constituição Federal para estender aos militares dos Estados, do Distrito Federal e dos Territórios o direito à acumulação de cargos públicos prevista no art. 37, inciso XVI.

Disponível em: 
http://www.planalto.gov.br/ccivil_03/constituicao/Emendas/Emc/emc101.htm. Acesso em: 09 set. 2019.

BRASIL. Lei $\mathbf{n}^{0}$ 8.112, de 11 de dezembro de 1990. Dispõe sobre o regime jurídico dos servidores públicos civis da União, das autarquias e das fundações públicas federais. Disponível em: http://www.planalto.gov.br/ccivil_03/LEIS/L8112cons.htm. Acesso em: 31 ago. 2019.

BRASIL. Superior Tribunal de Justiça (2. Turma). Recurso Especial 1.746.784/PE. Administrativo. Recurso especial. Servidor público. Acumulação de cargos públicos remunerados. Área de saúde. Limitação da carga horária. Impossibilidade. Incompatibilidade de horários. Requisito único. Aferição pela Administração Pública. Recurso especial provido. Recorrente: Maria Alves Feitosa Pinto. Min. Og Fernandes, 23 de agosto de 2018. Disponível em: https://stj.jusbrasil.com.br/jurisprudencia/631927666/recurso-especial-resp-1746784-pe2018-0139716-3/relatorio-e-voto-631927674?ref=juris-tabs. Acesso em: 31 ago. 2019.

BRASIL. Supremo Tribunal Federal (1. Turma). Agravo Regimental no Recurso Extraordinário 1.094.802/PE. Administrativo. Processual civil. Acumulação de cargos. Enfermagem. Carga horária superior às 60 (sessenta) horas semanais. Compatibilidade de horários a ser verificada caso a caso. Precedentes deste TRF5 e do STF. Apelação e remessa oficial desprovidas. Agravante: Empresa Brasileira de Serviços Hospitalares - EBSERH. Relator: Min. Alexandre de Moraes, 11 de maio de 2018. Disponível em: www.stf.jus.br/portal/processo/verProcessoPeca.asp?id=314421925\&tipoApp=.pdf. Acesso em: 31 ago. 2019.

DI PIETRO, Maria Sylvia Zanella. Direito Administrativo. 31 ed. rev. atual. e ampl. Rio de Janeiro: Forense: 2018.

GERHARDT, Tatiana Engel; SILVEIRA, Denise Tolfo. Métodos de Pesquisa. Coordenado pela Universidade Aberta do Brasil - UAB/UFRGS e pelo Curso de Graduação Tecnológica Planejamento e Gestão para o Desenvolvimento Rural da SEAD/UFRGS. 1. ed. Porto Alegre: Editora da UFRGS, 2009. Disponível em:

<http://www.ufrgs.br/cursopgdr/downloadsSerie/derad005.pdf>. Acesso em: 31 ago. 2019.

MEIRELLES, Hely Lopes. Direito Administrativo Brasileiro. 28. ed. São Paulo: Malheiros, 2003. 


\title{
WHATSAPP COMO INSTRUMENTO DE CONCILIAÇÃO NAS RECLAMAÇÕES TRABALHISTAS
}

\author{
WhatsApp as an instrument of conciliation in labor demands
}

\section{Letícia Ribeiro de Moraes}

\begin{abstract}
Pesquisadora do Laboratório Americano de Estudos Constitucionais Comparados (LAECC) e Inovação na Educação para prevenção de delitos praticados na juventude (INOVA-EDUCA). Graduação em Direito em andamento pela Universidade do Estado de Minas Gerais-UEMG/Frutal. Já atuou como estagiária na Delegacia de Polícia Civil da cidade de Frutal. Integrante da gestão 2019 do Centro Acadêmico de Direito da referida Universidade. Foi bolsista de Iniciação Científica, em 2018, pela Fundação de Amparo a Pesquisa de Minas Gerais (FAPEMIG). Interessa-se por temas que versam sobre Direitos Humanos, Direito Constitucional, Direito Processual Penal, Direito Penal e Direito do Trabalho. E-mail: le.ribeiom98@gmail.com
\end{abstract}

\section{Marcelo Braghini}

Professor Titular Concursado de Direito do Trabalho e Processo do Trabalho pela UEMG. Professor de Direito do Trabalho e Processo do Trabalho pela Unaerp. Mestre em Direito Constitucional pela Universidade de Ribeirão Preto, pós-graduado em Direito do Trabalho pela Pontifícia Universidade Católica de Goiás, e em Direito Tributário pelo Instituto Brasileiro de Direito Tributário; Graduado em Direito pela Universidade de Ribeirão Preto. Autor do livro: "Reforma Trabalhista: flexibilização das normas sociais do trabalho" 2017, pela editora LTr. E-mail: marcelo.braghini@uemg.br

Resumo: Este ensaio jurídico justifica-se pela necessidade do estudo de um tema ainda pouco debatido, mas que pode trazer enormes benefícios para o Poder Judiciário se for implementado de maneira correta. Objetiva-se, então, analisar a eficácia das mídias digitais, especialmente do aplicativo Whatsapp, durante as audiências de conciliação da Justiça do Trabalho. Para isso, optamos por realizar uma breve explanação a respeito da crise e do abarrotamento do sistema judiciário; estudar o conceito de conciliação e seus fundamentos no ordenamento jurídico; bem como entender o advento do Whatsapp no Brasil, visando compreender sua influência sobre os métodos alternativos de resolução de conflitos. A fim de alcançar tais objetivos, utilizou-se o método indutivo e a pesquisa teórica qualitativa baseada em fontes primárias de legislação e em fontes secundárias encontradas na doutrina. Conclui-se que a conciliação através do aplicativo Whatsapp é totalmente viável e traz benefícios tanto para as partes envolvidas, quanto para o Poder Judiciário.

Palavras-chave: Conciliação. Whatsapp. Celeridade.

\begin{abstract}
This legal essay is justified by the need of studying about a matter that's still been so little talked about, but that can bring enormous benefits to the Judiciary Branch, as long as it's correctly implemented. The point is to analyse the efficacy of digital media, especially the Whatsapp app, during Labor Justice's conciliation hearings. In this regard, we have opted to briefly explain the crises and the overcrowding of the Judiciary Branch, as well as studying the concept of conciliation and its grounds in the legal system, and understanding the arrival of Whatsapp in Brazil, aiming to understand its influence on alternative methods of conflict resolution. In order to achieve this objectives, the inductive method and the theorical research based on primary sources of legislation and secondary sources found in the doctrine were used.
\end{abstract}


It is concluded that conciliation through the Whatsapp app is totally viable and brings benefits to both the parties involved, as well as to the Judiciary Branch.

Keywords: Conciliation. Whatsapp. Agility

\section{INTRODUÇÃO}

Inegável o fato de que o Poder Judiciário encontra-se em um momento de crise. Tal problema tem origem na errônea cultura de judicialização instaurada no cotidiano brasileiro, a qual gera inúmeras demandas, normalmente de pouca complexidade, e que acabam abarrotando um sistema que já sofre com a falta de servidores e com procedimentos extremamente formais. Como consequência, o direito do acesso à justiça, constitucionalmente protegido, bem como o princípio da razoável duração do processo acabam sendo prejudicados.

Os esforços são constantes a fim de driblar esse momento caótico, como percebemos com as inúmeras medidas que vem sendo propostas. Como exemplo, podemos citar a criação da Lei 9.099/95, que instituiu os Juizados Especiais, e os meios alternativos de resolução de conflitos - mediação, conciliação e arbitragem - que ganharam força, principalmente, com o advento do Novo Código de Processo Civil.

Porém, a globalização e as relações sociais cada vez mais dinâmicas, provocaram uma agilidade na troca de informações e o Direito se vê obrigado a acompanhar e adaptar-se às modificações ocorridas em seu contexto social. Para isso, nada mais justo do que apropriar-se da tecnologia, presente na vida de todos, em seus procedimentos, visando alcançar uma maior celeridade e desburocratização. Um grande passo foi dado nessa direção com a instituição do Processo Judicial Eletrônico. Destacando diante da Reforma Trabalhista (Lei $\mathrm{n}^{\circ}$ 13.467/17) a nova ferramenta da homologação de transação extrajudicial, autorizada no art. 855-B da CLT como meio alternativo de solução de conflito por meio de jurisdição voluntária.

Nesse sentido, surge a seguinte interrogação: “Como a utilização das mídias digitais facilitaria o processo de conciliação das reclamações trabalhistas?”.

Por isso, a pesquisa tem como objetivo geral analisar a eficácia da aplicação das mídias digitais, especialmente do Whatsapp, durante audiências de conciliação da Justiça do Trabalho, a qual deveria, em tese, ter o procedimento mais célere. Já como objetivos específicos, realizarse á uma investigação a respeito do abarrotamento do sistema judiciário, relacionando-o com o princípio do acesso à justiça; estudar o conceito de conciliação e seus fundamentos no ordenamento jurídico; bem como entender o advento do Whatsapp no Brasil, visando compreender sua influência sobre os métodos alternativos de resolução de conflitos. 
Visando atingir os objetivos supracitados, utilizar-se-á do método indutivo e da pesquisa teórica qualitativa com fontes primárias de legislação, a exemplo do Novo Código de Processo Civil e da Consolidação das Leis Trabalhistas, jurisprudências, e fontes secundárias encontradas através na doutrina de autores como José Roberto Freire Pimenta, Gabriela Vasconcelos Lima e Gustavo Raposo Pereira Feitosa.

\section{A CRISE DO JUDICIÁRIO E O ACESSO À JUSTIÇA}

O Conselho Nacional de Justiça, todo ano, divulga o Relatório Justiça em Números, o qual traz a realidade dos tribunais brasileiros, demonstrando, inclusive, através de dados comprovados, que, a crise no Poder Judiciário, assunto tão recorrente, é verdadeira e caótica.

O Poder Judiciário finalizou o ano de 2017 com 80,1 milhões de processos em tramitação, aguardando alguma solução definitiva. Desses, 14,5 milhões, ou seja, 18,1\%, estavam suspensos, sobrestados ou em arquivo provisório, aguardando alguma situação jurídica futura. (CONSELHO NACIONAL DE JUSTIÇA, 2018, p. 72).

Rodolfo Camargo de Mancuso, em sua obra "Acesso à Justiça - condicionantes legítimas e ilegítimas", sistematiza as diversas causas que, a seu ver, colaboram para o abarrotamento do judiciário brasileiro:

(...) (a) desinformação ou oferta insuficiente quanto a outros meios, ditos alternativos, de auto e heterocomposição de litígios, gerando uma cultura da sentença, na expressão de Kazuo Watanabe; (b) exacerbada juridicização da vida em sociedade, para o que contribui a pródiga positivação de direitos e garantias, individuais e coletivos, a partir do texto constitucional, projetando ao interno da coletividade uma expectativa (utópica), de pronto atendimento a todo e qualquer interesse contrariado e insatisfeito; (c) ufanista e irrealista leitura do que contém no inciso XXXV do art. $5^{\circ}$ da CF/1988 - usualmente tomado como sede do acesso à Justiça - enunciado que, embora se enderece ao legislador, foi sendo gradualmente superdimensionado (ao influxo de motes como ubiquidade da justiça, universalidade da jurisdição), praticamente implicando em converter o que deverá ser o direito de ação (específico e condicionado) num prodigalizado dever de ação!; (d) crescimento desmesurado da estrutura judiciária - oferta de mais do mesmo sob a óptica quantitativa - com a incessante criação de novos órgãos singulares e colegiados, e correspondentes recursos humanos e materiais, engendrando o atual gigantismo que, sobre exigir parcelas cada vez mais expressivas do orçamento público, induz a que esse aumento da oferta contribua para retroalimentar a demanda (MANCUSO, 2011, pp. 52-53).

Portanto, depreende-se que paira, na sociedade atual, uma supervalorização à cultura de judicialização, ou seja, ao invés de lançarmos mão do Poder Judiciário como última opção, 
acabamos por enxergá-lo como a única saída capaz de resolver conflitos que poderiam ser dirimidos, na maioria das vezes, por meios alternativos e extrajudiciais.

\begin{abstract}
É preciso admitir, portanto, que é impossível à máquina judiciária estatal resolver todos os dissídios que lhe forem submetidos através de sentenças (as quais, em sua maioria, ainda precisarão ser executadas após o seu trânsito em julgado) - é que, se for preciso esgotar sempre todas as etapas e fases processuais necessárias para se chegar à efetiva satisfação dos direitos em definitivo reconhecidos como existentes, nunca haverá recursos públicos suficientes para montar e custear um aparato jurisdicional capaz de atender, em tempo razoável, a todos esses litígios. Diga-se expressamente: nenhum ramo do Poder Judiciário (e muito menos a Justiça do Trabalho brasileira) está preparado para instruir, julgar e, se necessário, executar as sentenças condenatórias proferidas em todos (ou quase todos) os processos que lhe forem ajuizados. As consequências desse quadro já são, aliás, de conhecimento geral e infelizmente estão presentes em vários setores do Judiciário brasileiro: uma Justiça assoberbada por um número excessivo de processos é inevitavelmente uma Justiça lenta e de baixa qualidade. Então, é de lógica e de bom senso trabalhar, estimular e explorar as múltiplas vertentes alternativas de solução dos conflitos de interesses, dentre as quais assume especial relevo a conciliação das partes. (PIMENTA, 2001, p.153).
\end{abstract}

Com isso, a máquina judiciária acaba ficando completamente abarrotada e, consequentemente, ineficiente, dificultando, que os cidadãos tenham o acesso à justiça de forma realmente efetiva.

Esse importantíssimo princípio está contemplado no artigo $5^{\mathrm{a}}, \mathrm{XXXV}$ da Constituição Federal: “A lei não excluirá da apreciação do Poder Judiciário lesão ou ameaça de direito”. Carlos Henrique Bezerra Leite (2017, p. 189) afirma que: "No sentido integral, acesso à Justiça significa também acesso à informação e à orientação jurídica, e a todos os meios alternativos de solução de conflitos, pois o acesso à ordem jurídica é, antes de tudo, uma questão de cidadania".

Nesse sentido, todos podem postular em juízo - inclusive sem advogado na Justiça do trabalho, através do jus postulandi - e receber a tutela jurisdicional.

\title{
2. A CONCILIAÇÃO NO ORDENAMENTO JURÍDICO BRASILEIRO
}

Ao observar que os procedimentos burocráticos, em virtude da morosidade gerada, estavam acabando por colocar a credibilidade do Poder Judiciário em jogo, tornou-se necessário pensar em soluções para esse problema, a fim de possibilitar que o Direito acompanhe a evolução da sociedade de forma tão rápida quanto.

Essa solução se caracteriza pelos meios alternativos de solução de conflitos. Dentre esses métodos, destaca-se a conciliação, objeto de nossa pesquisa, a qual busca, para além da celeridade processual, a manutenção do diálogo, da compreensão e da cultura da paz. 
Nesse sentido, Paulo César Santos Bezerra (2001, p. 137) afirma que:

O ideal das soluções dos conflitos é a prevenção dos conflitos. O ideal ao processo é o não-processo. Os processos decisórios não pacificam, antes suscitam mais conflitos. O fundamento econômico da prevenção, mediação, conciliação, etc. é a poupança de tempo, despesas e incômodos. O fundamento filosófico é o ideal da paz e o sociológico é a efetivação dessa mesma paz.

Ou seja, enquanto o processo judiciário acaba por provocar um distanciamento das partes, a conciliação traz uma posição equilibrada e apaziguadora para a demanda. Não haveria vencedores e vencidos, a conciliação deveria ser vista como a sentença dada pelas partes em conflito, por ser as mesmas conhecedoras da exata dimensão do conflito posto em juízo, e quais as reais possibilidades de convergência a ponto comum.

No que diz respeito à sua evolução histórica, a conciliação já fazia parte do judiciário brasileiro desde o período colonial, encontrando previsão nas Ordenações Manuelinas (1514) e Ordenações Filipinas (1603). Porém, no início do século XIX essa prática começou a ser esquecida, ressuscitando somente com o Código de Processo Civil de 1973, em virtude da sobrecarga do Poder Judiciário.

Com o advento da Constituição da República Federativa do Brasil de 1988, a necessidade de criação de juizados para as causas de menor complexidade ganhou caráter constitucional e, posteriormente, ocasionou a promulgação da Lei n ${ }^{\circ}$ 9.099/95 (Juizados Especiais Estaduais) e da Lei n ${ }^{\circ}$ 10.259/01 (Juizados Especiais Federais). O procedimento dos Juizados Especiais baseia-se na cooperação das partes litigantes para por fim a demanda, ou seja, ambos cedem um pouco de seus desejos buscando encontrar um acordo, utilizando apenas de um terceiro imparcial para conduzir a solução do conflito, bem com pela simplificação dos procedimentos, já que o processo não é visto como um fim em si mesmo, apenas um instrumento contemporâneo de pacificação social.

Ainda, com a entrada em vigor do Código de Processo Civil de 2015, esse instituto ganha mais visibilidade. A exemplo, podemos citar o artigo 334 do referido diploma legal, que estipula:

Art. 334. Se a petição inicial preencher os requisitos essenciais e não for hipótese de improcedência liminar do pedido, o juiz designará audiência de conciliação ou mediação com antecedência mínima de 30 (trinta) dias, devendo ser citado o réu com pelo menos 20 (vinte) dias de antecedência. (BRASIL, 2015)

No que diz respeito à Justiça do Trabalho, a Consolidação das Leis Trabalhistas atribui caráter obrigatório para a proposta de conciliação, a qual o Magistrado deve envidar todos os esforços necessários a sua efetivação, como exemplo tem-se o art. 764, que dispõe que: “Os 
dissídios individuais ou coletivos submetidos à apreciação da Justiça do Trabalho serão sempre sujeitos à conciliação". Ainda nesse sentido, é possível citar o artigo 831 da supracitada norma, o qual determina que a sentença só terá validade depois de rejeitada pelas partes a proposta de conciliação.

Nesse sentido, o TRT-24 decidiu:

NULIDADE. AUSÊNCIA DE TENTATIVA DE CONCILIAÇÃO - O texto expresso e imperativo contido no art. 764 da CLT é no sentido de propiciar a conciliação. Não sendo observada essa exigência legal, deve-se anular o processo. Nesse contexto, o acordo firmado em outro processo no qual a autora não participou a qualquer título, não tem o condão de produzir efeitos em outra relação processual, a ponto de dispensar a realização de audiência e a tentativa de conciliação, requisito de validade da própria relação processual (arts. 764 e 852-E da CLT), máxime quando se julga improcedente certas pretensões que poderiam ser deferidas com a produção da prova que a autora tem direito de produzir, e pela qual protestou na inicial. Violação das garantias constantes do art. $5^{\circ}$, incisos LIV e LV, do Texto Supremo, que leva a anulação da sentença com reabertura da instrução para que o devido processo e procedimento legal sejam observados. (TRT-24, 2011)

Ressalta-se que a conciliação tem caráter permanente e com validade jurídica, visto que os acordos oriundos da conciliação, respeitando os procedimentos referentes a cada rito, serão analisados e homologados pelo juiz.

Percebe-se que, na Justiça do Trabalho, a conciliação exerce um papel ainda mais importante. Isso decorre do fato de que a parte hipossuficiente - o empregado - precisa da efetivação de seus direitos da forma mais rápida possível, visto que pleiteia, na maioria das vezes, por verbas de caráter alimentar e, com a morosidade processual, não tem condições de arcar com os custos da tramitação do processo, colocando em risco a sobrevivência própria e de sua família.

\section{O ADVENTO DO WHATSAPP E SUA INFLUÊNCIA SOBRE AS CONCILIAÇÕES: O PROJETO MÍDIA E MEDIAÇÃO}

\subsection{Breve histórico e conceito}

O aplicativo Whatsapp, hoje mundialmente conhecido, foi criado no ano de 2009 por dois ex-funcionários da Yahoo - Jan Koum e Brian Action - e, posteriormente, foi vendido para o Facebook em 2014 por 19 bilhões de dólares.

O referido é um aplicativo gratuito de troca de mensagens, com recursos de áudio e vídeo pela internet, e está disponível para Android, iOS, Windows Phone, Nokia e para computadores Mac e Windows. De acordo com dados da empresa de análise de mercado App 
Annie, apesar de não haver dados exatos, estima-se que o serviço tem cerca de 200 milhões de usuários mensais.

Com relação ao mercado brasileiro, o Whatsapp abrange cerca de $56 \%$ da população brasileira, facilitando, portanto, a comunicação para qualquer lugar do mundo.

É sabido que a sociedade deve usar das inovações para buscar sua evolução, o que não foi diferente no que diz respeito ao aplicativo supracitado. Atualmente, essa mídia digital vem sendo usada, inclusive, pelos empresários, visto que acaba por melhorar e agilizar o atendimento, reforçando o vínculo com os consumidores, além de ser um investimento de baixo custo e fácil acesso.

\subsection{Aplicação pelo Poder Judiciário}

Não diferentemente dos demais ramos da sociedade, o Direito tem como obrigação adaptar-se à evolução da sociedade, pois, somente assim, consegue satisfazer o interesse de seus jurisdicionados por completo.

Nesse sentido, Michelle Pires Bandeira Pombo (2016, p. 169) afirma que: “ [...] faz-se necessário um aperfeiçoamento da prestação jurisdicional, no sentido de melhorar e modernizar o processo judicial e seus procedimentos”. Acredita, ainda, ser imprescindível: “ [...] a reformulação de procedimentos judiciais ante a exigência de uma nova visão social do processo e, por conseguinte, uma nova postura processual com o fim de se chegar mais próximo a verdade real dos fatos".

Depreende-se, portanto, que uma estrutura judiciária abarrotada de demandas, com déficits de serventuários, deve-se valer de todos os meios possíveis para a efetivação dos direitos e alcance da duração razoável do processo. O primeiro passo nessa direção foi dado com os meios alternativos de solução de conflitos. Já em outro momento, podemos citar a utilização de mídias digitais no processo.

O primeiro ponto a ser destacado é o PJe ( Processo Judicial Eletrônico), lançado oficialmente em 2011 pelo então presidente do CNJ César Peluso. Tal dispositivo busca manter um sistema judicial eletrônico que permite o acompanhamento e prática de todos os atos judiciais, propondo uma maior celeridade e economia de gastos. Importante ressaltar que o PJe exige a certificação digital de todos que o utilizarem.

Quando o assunto é a realização dos métodos alternativos de solução de conflitos por meios digitais, encontramos, em nosso ordenamento jurídico, diversos dispositivos que a permitem. Como primeiro exemplo, cita-se o artigo $334, \S 7^{\circ}$ do Código de Processo Civil que proclama que " a audiência de conciliação e mediação pode realizar-se por meio eletrônico, nos 
termos da lei”. Ainda, encontramos dispositivo similar na Lei de Mediação (Lei nº 13.140/2015) em seu artigo 46: “A mediação poderá ser feita pela internet ou por outro meio que permita a transação à distância, desde que as partes estejam de acordo".

Por fim, cabível destacar a Resolução Administrativa nº12/2014 do TRT15, que "Criou os Centros Integrados de Conciliação do Tribunal Regional do Trabalho da $15^{\text {a }}$ Região", a qual menciona em seu artigo $9^{\circ}, \S 3^{\circ}$ que:

Art. $9^{\circ}$. [...].

$\S 3^{\circ}$. Os Centros Integrados de Conciliação poderão se valer de recursos tecnológicos que permitam realizar negociações com segurança, inclusive por via eletrônica, mediante sistemas de videoconferência ou similares e que assegurem a ampla negociação, bem como inequívoca e livre manifestação de vontade das partes interessadas.

Insta salientar que em países como os Estados Unidos a utilização das mídias digitais de comunicação para resolução de conflitos judiciais já foi aderida e é chamada de ODR (Online Dispute Resolution). Segundo Gabriela Vasconcelos Lima e Gustavo Raposo Pereira Feitosa (2016, p. 54) :

A chamada ODR consiste na utilização da tecnologia da informação e da comunicação no processo de solução de conflitos, seja na totalidade do procedimento ou somente em parte deste. Dentre os procedimentos que podem adotar o modelo da ODRs, estão a arbitragem, a mediação, a conciliação ou a negociação, que o fazem por intermédio de ferramentas automatizadas (total ou parcialmente). Essa solução representa uma forma de virtualização plena, em que um procedimento nasce e morre no ambiente virtual, sem necessidade de passar por etapas presenciais ou no espaço forense.

Conclui-se, portanto, que a conciliação através de mídias digitais é totalmente viável, visto que encontra fundamentos jurídicos e sua eficácia já vem sendo comprovada em Âmbito internacional.

\subsection{O Projeto Mídia e Mediação}

Como supracitado, o acesso à justiça, por se tratar de um direito fundamental, deve ser garantido à todos os cidadãos. Porém, devido à morosidade processual e ao abarrotamento do Judiciário, esse direito encontra algumas barreiras para sua efetivação. Uma das soluções encontradas para tal problema foram os meios alternativos de solução de conflitos, dentre eles a conciliação.

Entretanto, a conciliação em sua forma usual pode, ainda, trazer alguns contratempos que acabam por prejudicar as partes a duração razoável do processo. Como exemplo, pode-se citar o tempo de locomoção das partes até o local da audiência, a disponibilidade dos envolvidos 
de estarem presentes na mesma data e o pequeno espaço de tempo disponível para conciliação, o que prejudica a realização de um acordo.

Ao observar essa situação, a juíza Ana Cláudia Torres Viana, visando atender as necessidades de seus jurisdicionados e de aumentar o número de atendimentos, decidiu implementar, em 2015, o projeto Mídia e Mediação, com a ajuda da equipe do CEJUSC de $1^{\circ}$ grau do Tribunal Regional do Trabalho da $15^{\text {a }}$ Região.

Tal projeto consiste na utilização de celulares e tablets para a realização das audiências de conciliação da Justiça do Trabalho através do aplicativo Whatsapp, o que permite que os envolvidos possam realizar os atos cabíveis em ambientes mais confortáveis, além de disponibilizar um tempo muito maior para a realização do acordo.

Durante a realização do procedimento específico do projeto, preza-se sempre pela autonomia da vontade, sendo que as partes só permanecessem no grupo destinado ao processo de conciliação até o momento em que desejarem.

Ressalta-se, ainda, que apesar de não existir, no ordenamento jurídico brasileiro, um dispositivo específico para a conciliação através do Whatsapp, diversos dispositivos, conforme citados anteriormente, respaldam a prática do ato por vias eletrônicas.

De acordo com dados do CEJUSC da $15^{\text {a }}$ Região, no ano de 2016, foram realizadas 104 audiências de conciliação pelo aplicativo 186 WhatsApp. Dessas 104 audiências, 87 obtiveram sucesso com acordo (84\%) e 17 não obtiveram acordo (16\%).

O projeto foi tão efetivo e ganhou tanto reconhecimento que, no ano de 2015, recebeu menção honrosa na categoria "juiz individual" na $6^{a}$ edição do prêmio "Conciliar é legal" do Conselho Nacional de Justiça. Ainda, em 2016, obteve menção honrosa na categoria "juiz" da $13^{\mathrm{a}}$ edição do Prêmio Innovare.

\subsubsection{Vantagens e desvantagens para as partes}

Como dito anteriormente, a utilização da conciliação ao invés da judicialização desenfreada tem como finalidade a manutenção da cultura da paz, visto que as partes usam do diálogo e da compreensão para chegar a um acordo que agrade ambos. Por isso, o Whatsapp como ferramenta desse instituto prioriza ainda mais essa finalidade.

Isso ocorre porque os envolvidos possuem uma grande familiaridade e amplo acesso ao aplicativo, provocando uma sensação de confiança, já que podem realizar os acordos nos locais em que se sentirem mais confortáveis e no tempo que preferirem, o que difere-se do comportamento adotado no fórum - local caracterizado pela formalidade em todos os aspectos. 
Além disso, os princípios do acesso à justiça e da duração razoável do processo ganham destaque, devido a agilidade nos atendimentos dada por tal aplicativo e ao baixo custo de implementação e uso, o que agrada tanto ao Poder Judiciário quanto às partes.

Deve-se ressaltar, ainda, que a utilização desse instrumento rotineiro acaba por proporcionar uma aproximação entre os litigantes e com a Justiça, permitindo que o diálogo e as negociações se estendam por dias, não ficando restritas ao pequeno tempo estipulado durante as audiências. Ademais, esse procedimento reduz significamente o congestionamento do Poder Judiciário brasileiro.

Como pontos negativos, apesar de serem problemas de fácil solução, podemos elencar a necessidade de uma conexão com a internet, o que gera um custo - ainda que baixo - para as partes. No mesmo sentido, refere-se às despesas para adquirir um celular ou tablet compatível com as configurações do aplicativo Whatsapp, as quais beiram a quantia de duzentos e cinquenta reais.

Porém, apesar de encontrarmos obstáculos no tocante a tais despesas, o Whatsapp e a Internet estão difundidas para grande parte da população brasileira, o que permite que as inúmeras vantagens elencadas sobressaiam-se aos pontos negativos acima.

\section{CONCLUSÃO}

O presente trabalho teve como intuito estudar como o Whatsapp pode servir de instrumento para a realização de conciliações, visando garantir o acesso à justiça. Assim, em um primeiro momento, buscou-se analisar os motivos da crise que aflige o Judiciário brasileiro. Após, estudou-se, ainda, como a conciliação, forma autocompositiva de solução de conflitos, pode surgir como alternativa à morosidade processual. Por fim, analisou-se como a tecnologia - principalmente o aplicativo Whatsapp - pode influenciar positivamente no desenrolar da audiências de conciliação, trazendo como exemplos o ODR ( Online Dispute Resolution) e o Projeto Mídia e Mediação.

Foi possível notar que, em tempos de crise do Poder Judiciário, devemos buscar soluções que possam otimizar seu sistema e provocar seu descongestionamento, surgindo daí a importância dos métodos alternativos de solução de conflitos, a exemplo da conciliação.

Porém, é necessário observar as necessidades especiais que possuem alguns de seus jurisdicionados e, visando atender tais necessidades, o sistema judiciário deve acompanhar a evolução da sociedade e das tecnologias. Fundada nesse contexto, encontra-se a ideia de utilização das mídias digitais - a exemplo do Whatsapp - como instrumento de reclamações, proposta já aderida pelo Tribunal Regional do Trabalho da $15^{a}$ Região. 
Através desse trabalho, portanto, chegamos à conclusão de que é totalmente viável a conciliação via WhatsApp, pois é uma forma de acesso à Justiça, celeridade, com otimização de recursos financeiros e tempo para o Estado e cidadão, além de propagar e estimular a cultura da paz e diálogo, imprescindíveis, atualmente, para uma sociedade mais humanizada, que respeite os sentimentos e pensamentos alheios e como forma de tentar diminuir - e quem sabe, com o tempo, eliminar - a crise que cerca o Judiciário.

\section{REFERÊNCIAS}

_. Prêmio Innovare anuncia práticas vencedoras de 2016. Disponível em:

file://C:/Users/Usuario/Downloads/Release_Premia\%C3\%A7\%C3\%A3o_2016.pdf. Acesso em 09 set. 2019

BEZERRA, Paulo César Santos. Acesso à justiça: um problema ético-social no plano da realização do direito. Rio de Janeiro: Renovar, 2001.

BRASIL. [Constituição (1988)]. Constituição da República Federativa do Brasil de 1988. Brasília, DF: Presidente da República. Disponível em:

<http://www.planalto.gov.br/ccivil_03/constituicao/constituicaocompilado.htm>. Acesso em 21 de mar. de 2019.

BRASIL. Decreto-lei $\mathbf{n}^{0}$ 5.452, de $1^{\circ}$ de maio de 1943. Consolidação das Leis do Trabalho. Brasília, DF: Presidente da República. Disponível em:

http://www.planalto.gov.br/ccivil_03/Decreto-Lei/Del5452.htm. Acesso em 9 set. 2019

BRASIL. Lei no 13.105, de 16 de março de 2015. Código de Processo Civil. Brasília, DF: Presidente da República. Disponível em: http://www.planalto.gov.br/ccivil_03/_ato20152018/2015/lei/l13105.htm. Acesso em 9 set. 2019.

BRASIL. Lei $\mathbf{n}^{\mathbf{0}}$ 13.140, de 26 de junho de 2015. Dispõe sobre a mediação entre particulares como meio de solução de controvérsias e sobre a autocomposição de conflitos no âmbito da administração pública; altera a Lei $n^{\circ} 9.469$, de 10 de julho de 1997 , e o Decreto ${ }^{\circ} 70.235$, de 6 de março de 1972; e revoga o $\S 2^{\circ}$ do art. $6^{\circ}$ da Lei $\mathrm{n}^{\circ} 9.469$, de 10 de julho de 1997.Brasília, DF: Presidente da República. Disponível em: http://www.planalto.gov.br/ccivil_03/_ato2015-2018/2015/Lei/L13140.htm. Acesso 09 set. 2019.

BRASIL. Tribunal Regional do Trabalho - 24 Região (2 ${ }^{\text {a }}$ Turma). Processo no . 00007114420105240007. NULIDADE. AUSÊNCIA DE TENTATIVA DE CONCILIAÇÃO - O texto expresso e imperativo contido no art. 764 da CLT é no sentido de propiciar a conciliação. Não sendo observada essa exigência legal, deve-se anular o processo. Nesse contexto, o acordo firmado em outro processo no qual a autora não participou a qualquer título, não tem o condão de produzir efeitos em outra relação processual, a ponto de dispensar a realização de audiência e a tentativa de conciliação, requisito de validade da própria relação processual (arts. 764 e 852-E da CLT), máxime 
quando se julga improcedente certas pretensões que poderiam ser deferidas com a produção da prova que a autora tem direito de produzir, e pela qual protestou na inicial. Violação das garantias constantes do art. $5^{\circ}$, incisos LIV e LV, do Texto Supremo, que leva a anulação da sentença com reabertura da instrução para que o devido processo e procedimento legal sejam observados. Relator: Francisco das C. Lima Filho, Data de Publicação: 01/02/2011. Disponível em: https://trt-

24.jusbrasil.com.br/jurisprudencia/417443320/7114420105240007?ref=serp. Acesso em 09 set. 2019.

CONSELHO NACIONAL DE JUSTIÇA. Escolhidos os vencedores do Prêmio Conciliar é legal. Disponível em: http://cnj.jus.br/noticias/cnj/82140-escolhidos-os-vencedores-dopremio-conciliar-e-legal. Acesso em 09 set. 2019

CONSELHO NACIONAL DE JUSTIÇA. Relatório Justiça em Números. Brasília: CNJ, 2018. Disponível em:

https://www.cnj.jus.br/files/conteudo/arquivo/2018/08/44b7368ec6f888b383f6c3de40c32167. pdf. Acesso em 09 set. 2019.

LEITE, Carlos Henrique Bezerra. Curso de Direito Processual do Trabalho. $15^{\text {a }}$ ed. São Paulo: Saraiva, 2017.

LIMA, Gabriela Vasconcelos; FEITOSA, Gustavo Raposo Pereira. Online dispute resolution (ODR): a solução de conflitos e as novas tecnologias. Santa Cruz do Sul: Revista do Direito, n.50, v.3, p. 53-70, set/dez 2016.

MANCUSO, Rodolfo de Camargo. Acesso à justiça: condicionantes legítimas e ilegítimas. São Paulo: RT, 2011.

PIMENTA, José Roberto Freire. A conciliação judicial na Justiça do Trabalho após a Emenda Constitucional n. 24/99: aspectos de direito comparado e o novo papel do juiz do trabalho. São Paulo: Revista LTr, v. 65, n. 02, fev. 2001.

POMBO, Michelle Pires Bandeira. As ondas renovatórias do acesso à justiça no processo do trabalho. São Paulo: LTr, 2016.

TRIBUNAL REGIONAL DO TRABALHO DA 15 REGIÃO. Resolução Administrativa no 12/2014. Criou os Centros Integrados de Conciliação no âmbito do Tribunal Regional do Trabalho da $15^{\text {a }}$ Região. Campinas, SP, 2014. Disponível em: http://portal.trt15.jus.br/web/presidencia/resolucoes-administrativas-2014//asset_publisher/2zlYYIHmA53n/content/resolucao-administrativa-n-12-2014. Acesso em 09 set. 2019. 


\title{
A RESPONSABILIDADE DO ESTADO NOS CASOS DE OMISSÃO FISCALIZATÓRIA AMBIENTAL
}

\author{
The State's liability in case of environmental inspectional omission
}

\section{Leonardo de Andrade Alberto}

Pesquisador bolsista em Iniciação Científica do Programa Institucional de Apoio à PesquisaPAPq/UEMG. Pesquisador vinculado a Laboratório Americano de Estudos Constitucionais Comparados (LAECC). Presidente da Gestão 2019 da Avance Consultoria Júnior. Graduação em Direito em andamento pela Universidade do Estado de Minas Gerais-UEMG/Frutal. Formado em Técnico em Administração pela Escola Técnica Elias Nechar. Já atuou como estagiário em órgãos do executivo, legislativo e da polícia judiciária. Interessa-se por temas que versam sobre Direitos Humanos, Direito Internacional Público, Direito Constitucional, Direito Penal, Direito Comparado e Direito Digital com experiência em pesquisa e publicação.

\section{Beatriz de Lima Cardoso}

Graduação em Direito em andamento pela Universidade do Estado de Minas Gerais UEMG/Frutal. Interessa-se por temas que versam sobre Direito Penal, Direito Internacional e Direito Constitucional, com experiência em pesquisa e publicação, bem como em projetos de extensão. Email: bl_cardoso@hotmail.com

André Serotini

Doutor em Ciência Política pela Universidade Federal de São Carlos - PPGPOL/UFSCar (2014). Mestre em Desenvolvimento Regional e Meio Ambiente pelo Centro Universitário de Araraquara UNIARA (2005). Especialista em Direito Público, Educação Ambiental e Gestão Educacional. Professor de Direito Ambiental do Curso de Direito e do Programa de Mestrado em Ciências Ambientais da Universidade do Estado de Minas Gerais - UEMG - Unidade Frutal. Professor do Curso de Direito do Centro Universitário Central Paulista - UNICEP. Pesquisador do Núcleo de Estudos em Gestão e Impactos Ambientais - NEGIA, da UEMG - Frutal. Advogado e Consultor Jurídico com atuação em Direito Ambiental. E-mail: andre.serotini@uemg.br

Resumo: A Constituição da República Federativa do Brasil de 1988 dispõe, em seu artigo 225, parágrafo único, uma série de deveres incumbidos ao Poder Público acerca da proteção e preservação do meio ambiente equilibrado, sendo este um direito de todo cidadão, segundo o caput do mesmo artigo. Tendo a Carta Magna disposto sobre o dever legal de cuidado ao Estado, faz-se necessário compreender de que forma se dá a responsabilização do Poder Público quando este negligencia este mesmo dever. A discussão jurisprudencial sobre a qual se debruça o presente estudo se baseia no caráter objetivo ou subjetivo da responsabilidade civil do Estado, em caso de danos ambientais provocados por terceiros. Nestes casos, é importante a discussão acerca do perigo causado pela responsabilização total do Poder Público por ato ilícito cometido por terceiro, situação na qual poderá se subentender o Estado como uma espécie de segurador integral do equilíbrio do meio ambiente. Ocorre que a objetividade - ou subjetividade - da responsabilidade influencia diretamente na coerção que sofrerá o agente - o Estado - para que cumpra com a sua obrigação. Dada a natureza deveras importante da manutenção e proteção do meio ambiente, deve-se responsabilizar o Poder Público, de forma severa, em caso de negligência de seu dever legal de vigilância e proteção. Neste sentido, o presente estudo analisa a doutrina e a jurisprudência acerca da responsabilidade do Estado por sua omissão, em caso de degradação ambiental causada por um particular. 
Palavras-chaves: Responsabilidade civil; Omissão estatal; Direito Ambiental.

\begin{abstract}
The 1988 Constitution of the Federative Republic of Brazil says, in its 225th article, single paragraph, certain obligations detained by the Public Authorities about the protection and preservation of the balanced environment, this being a right of every citizen, according to the same article se caption. Once the Constitution has said about the State se legal duty of care, it s necessary to understand the Public Authorities "e responsibilization, when it neglects this care. The judicial discussion, which is the matter of this paper, is based on the subjective or objective aspect of the State ${ }^{\text {ee }}$ liability, in case of environmental damage caused by third parties. In these cases, it ${ }^{\text {ee }}$ importante to discuss about the danger caused by the total liability of the Public Authorities for third partiese actions, leading to a situation in which the State can be seen as a full ensurer of the environmental balance. However, the objectivity - or subjectivity - of the liability influences directly the coercion that will be suffered by the agent

- in this case, the State - so that they do their obligation. Considering the important nature of the environment ${ }^{\text {ec }}$ s keeping and protection, the Public Authorities must be severely liable for its negligence on its legal duty of protection. This paper analyzes the doctrine and the judicial habits about the State ${ }^{\text {ee }}$ liability for its omission, in case of environmental damage caused by a third party.
\end{abstract}

Palavras-chaves: Civil liability; State omission; Environmental law.

\title{
INTRODUÇÃO
}

A Constituição da República Federativa do Brasil de 1988 no artigo 37, §6º e o Código Civil no artigo 186 tratam a respeito do instituto jurídico da reparação civil sendo como toda ação ou omissão que viole um direito ou cause dano a um ato ilícito gerando assim, o dever de reparação, ou seja, voltar ao status quo ante do dano causado. Todavia, o dever de reparação é classificado sob duas formas: contratual (derivada do não cumprimento de um dever preexistente) e extracontratual (sem dever pré-estabelecido).

A responsabilidade extracontratual pode ser dividida em subjetiva e objetiva. A primeira, como sendo regra geral, baseia-se na teoria da culpa, sendo necessários três elementos caraterizadores: ato ilícito (culposo ou doloso); dano; e nexo de causalidade.

Já na responsabilidade extracontratual objetiva, caracterizada como exceção, a culpa é substituída pela teoria do risco, não sendo necessária a existência de culpa ou dolo para a reparação do dano causado e é aplicada, como por exemplo, na responsabilidade estatal perante algum dano.

A Política Nacional do Meio Ambiente, lei nº6.938 de 31 de agosto de 1981, dispõe no artigo $14, \S 1^{\circ}$ que o dever de reparação aos danos causados ao meio ambiente independe de 
culpa, adotando-se assim a responsabilidade objetiva. Tal instrumento e a Constituição da República tratam o meio ambiente ecologicamente equilibrado como um direito fundamental, conforme direito humano reconhecido pela Declaração de Estocolmo das Nações Unidas sobre Ambiente Humano de 1972.

Neste sentido, uma vasta gama de princípios orientam as relações ambientais, porém o principio do poluidor-pagador é considerado como fundamental e está disposto no artigo $3^{\circ}$, inciso IV, da Política supracitada. Tal princípio refere-se a imposição - sem caráter punitivode recuperar, quando possível, os danos causados ao meio ambiente e, quando impossível, o pagamento em pecúnia (revertido a preservação do meio ambiente), visando a observância do princípio da reparação in integrum.

Conforme dito, a responsabilidade do Estado é, em regra, objetiva, porém nos atos omissivos é possível que ela seja caracterizada como subjetiva em decorrência do artigo 225 da Constituição da República, que preceitua ser imposto ao Poder Público o dever de preservar e defender o meio ambiente ecologicamente equilibrado.

Deste modo, a problematização do presente trabalho surge tendo em vista a existência de duas correntes jurisprudenciais que ora classifica a responsabilidade civil do Estado em objetiva (Recurso Especial 1.071.741 STJ) ora em subjetiva (Recurso Especial 647.493/SC STJ).

Portanto, este artigo, pautado em pesquisa bibliográfica e documental de natureza qualitativa, busca discutir a objetividade ou subjetividade da responsabilidade civil do Estado inferida por sua omissão fiscalizatória, especificamente em caso de dano ambiental causado por particulares analisando brevemente a doutrina e os julgados acima citados.

\section{RESPONSABILIDADE CIVIL}

Historicamente, a responsabilidade surge sem a demonstração de culpa no Direito Romano quando o causador de um dano era punido com base na Lei das XII Tábuas, na pena de "olho por olho, dente por dente". Tal responsabilidade foi evoluindo e "afastou-se a ideia de pena para substituí-la por aquela de reparação do dano sofrido" (SILVA, 2005, p.427). Todavia, faz-se necessário elucidar que

[...] a culpa do Direito Romano é diferente da culpa atual, pois a última, ao contrário da anterior, traz em seu conteúdo a ideia de castigo, por forte influência da Igreja Católica. Como os romanos eram essencialmente pragmáticos, a culpa era, antes de qualquer coisa, mero pressuposto do dever de indenizar. (TARTUCE, 2017, p.372) 
Atualmente, a responsabilidade civil é conceituada como “[...] a reparação dos injustos, resultantes da violação de um dever de cuidado" (PINTO, 2019, p. 631) e tem como pressupostos o ato ilícito ou conduta, a culpa, o dano e o nexo de causalidade.

O ato ilícito diz respeito "[...] a conduta contrária ao ordenamento jurídico, sendo seus elementos a antijuridicidade e a imputabilidade" (PINTO, 2019, p. 631). O Código Civil brasileiro em seu artigo 186 dispõe que "Aquele que, por ação ou omissão voluntária, negligência ou imprudência, violar direito e causar dano a outrem, ainda que exclusivamente moral, comete ato ilícito".

Neste sentido, surge a culpa que, em sentido stricto sensu, pode ser classificada como contratual ou extracontratual (ou aquiliana) e a diferença entre ambas está na existência ou não de uma relação jurídica entre as partes anterior ao ato ilícito.

A culpa contratual advém "[...] da força obrigatória do contrato (pacta sunt servanda), que traz a previsão pela qual as cláusulas contratuais devem ser respeitadas, sob pena de responsabilidade daquele que as descumprir por dolo ou culpa" (TARTUCE, 2017, p.389).

Em contraposição há a extracontratual que “[...] ocorre quando, entre o autor do dano e a vítima, não há nenhuma relação jurídica anterior" (PINTO, 2019, p. 631). Neste sentido, o Código Civil em seu artigo 927 prevê que "aquele que, por ato ilícito causar dano a outrem, fica obrigado a repará-lo".

Assim, o ato ilícito é o "[...] desacordo com a ordem jurídica violando direitos e causando prejuízos a outrem. Diante da sua ocorrência a norma jurídica cria o dever de reparar o dano [...]" (TARTUCE, 2017, p.390). Dano este que pode ser material, moral, estético, coletivo e social. Tendo em vista o objetivo do presente trabalho, não faz-se necessário aprofundar conhecimentos nos vários tipos de dano.

Por fim, há o nexo de causalidade que é o elo entre a conduta e o dano, ou seja, “[...] constitui o elemento imaterial ou virtual da responsabilidade civil, constituindo a relação de causa e efeito entre a conduta culposa ou o risco criado e o dano suportado por alguém" (TARTUCE, 2017, p. 447).

\section{RESPONSABILIDADE CIVIL DO ESTADO}

A responsabilidade civil do Estado, em caso de dano causado a particulares ocorre, em regra, na modalidade aquiliana. Isto ocorre em decorrência do princípio da isonomia, uma vez que 
deve haver igual repartição dos encargos públicos entre os cidadãos, pois, se em razão de atividade administrativa somente alguns particulares sofreram danos especiais e anormais, isto é, que não são comuns na vida social, haveria um desequilíbrio na distribuição dos ônus públicos se somente eles suportassem o peso daquela atividade. (DINIZ; MIRANDA, 2013, p. 679)

A objetividade da responsabilidade civil do Estado pode ser observada no $\S 6^{\circ}$ do art. 37 da Constituição Federal de 1988, que elucida:

As pessoas jurídicas de direito público e as de direito privado prestadoras de serviços públicos responderão pelos danos que seus agentes, nessa qualidade, causarem a terceiros, assegurado o direito de regresso contra os responsáveis no caso de dolo ou culpa. (CF, 1988).

Conforme já dito no presente trabalho, a responsabilidade do Estado é, em regra, objetiva, e não deveria ser diferente no Direito Ambiental. Segundo a Política Nacional do Meio Ambiente, lei nº6.938 de 31 de agosto de 1981, "apontado como um dos mais relevantes instrumentos legais de regulamentação ambiental” (THOMÉ, 2019, p.193) o poluidor é “obrigado, independentemente da existência de culpa, a indenizar ou reparar os danos causados ao meio ambiente e a terceiros, afetados por sua atividade". Tal instrumento e a Constituição da República tratam o meio ambiente ecologicamente equilibrado como um direito fundamental, conforme direito humano reconhecido pela Declaração de Estocolmo das Nações Unidas sobre Ambiente Humano de 1972.

Neste sentido, uma vasta gama de princípios orientam as relações ambientais, porém o principio do poluidor-pagador é considerado como fundamental e está disposto no artigo $3^{\circ}$, inciso IV, da Política supracitada, como sendo "poluidor, a pessoa física ou jurídica, de direito público ou privado, responsável, direta ou indiretamente, por atividade causadora de degradação ambiental". A definição do conceito de poluidor claramente inclui o Estado, quando este, por meio de quaisquer atividades naturais, causa danos ao bem-estar ambiental.

O poluidor, de fato, seja ele particular ou um ente público, tem responsabilidade sobre a degradação que causa, como consta no artigo $4^{\circ}$, inciso VII, que diz que a Política visará "à imposição, ao poluidor e ao predador, da obrigação de recuperar e/ou indenizar os danos causados $[\ldots]$... Assim, Carlos Eduardo Volante ensina:

A atividade poluente acaba sendo uma apropriação pelo poluidor dos direitos de outrem, pois na realidade a emissão poluente representa um confisco do direito de alguém em respirar ar puro, beber água saudável, e viver com tranquilidade. Por isso, é imperioso que se analisem oportunamente as modalidades de reparação do dano ecológico, pois muitas vezes não basta indenizar, mas fazer cessar a causa do mal [...]". (MACHADO, 2008 apud. VOLANTE, 2012, p.34). 
Portanto, o principio do poluidor-pagador refere-se a imposição de recuperar, quando possível, os danos causados ao meio ambiente e, quando impossível, o pagamento em pecúnia (revertido a preservação do meio ambiente), visando a observância do princípio da reparação in integrum. Entende-se que a atividade que explora qualquer recurso natural implica em risco para a sociedade e, portanto, este mesmo risco deve gerar a objetividade da responsabilidade civil do agente que a exercer. (VOLANTE, 2012).

Sendo assim, seja através da regra da objetividade da responsabilidade civil do Estado sobre os danos que este causa a terceiros, seja através da objetividade da responsabilidade do poluidor sobre os danos que este causa ao meio ambiente, não resta dúvidas de que o Estado é objetivamente responsável por suas ações no âmbito do Direito Ambiental.

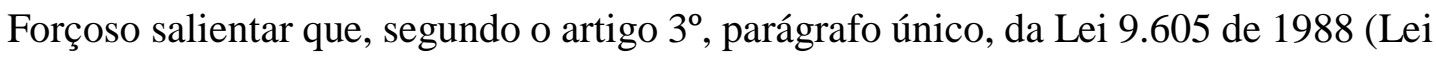
de Crimes Ambientais), “a responsabilidade das pessoas jurídicas não exclui a das pessoas físicas, autoras, coautoras ou partícipes do mesmo fato".

Assim, após análise da responsabilidade do Estado, passemos ao estudo da omissão estatal.

No que tange à responsabilidade do Estado por sua omissão administrativa, há controvérsias se a responsabilidade seria objetiva ou subjetiva. Os autores que sustentam a primeira tese dizem que "[...] basta demonstrar que o prejuízo sofrido tece um nexo de causa e efeito com o ato comissivo ou com a omissão. Não haveria que se cogitar de culpa ou dolo, mesmo no caso de omissão.” (DI PIETRO, 2017, p. 827).

Já os sustentadores da segunda tese dizem que a omissão seria subjetiva tendo em vista a aplicação da “[...] teoria da culpa do serviço público ou da culpa anônima do serviço público (porque seria indiferente saber quem é o agente público responsável)", pois baseado na teoria "[...] o Estado responde desde que o serviço público (a) não funcione, quando deveria funcionar; (b) funcione atrasado; ou (c) funcione mal. Nas duas primeiras hipóteses, tem-se a omissão danosa" (DI PIETRO, 2017, p. 827).

No mesmo sentido, Thomé também segue esta segunda corrente, defendendo que a responsabilidade seja "condicionado à comprovação, além do dano e do nexo causal, da culpa (lato sensu), admitindo a aplicação da culpa anônima ou culpa do serviço, que se contenta com a comprovação de que o serviço não foi prestado, ou foi prestado de forma ineficiente". (THOMÉ, 2019, p.621)

Especificamente no âmbito do Direito Ambiental, não se pode ignorar que o art. 225 da Constituição Federal de 1988 preceitua ser imposto ao Poder Público o dever de preservar e defender o meio ambiente ecologicamente equilibrado. 
A fiscalização, importante parte do supracitado dever, integra a noção de prevenção, que constitui princípio básico do Direito Ambiental:

Em Direito Ambiental, deve-se sempre que possível buscar a prevenção, pois remediar normalmente não é possível, dada à natureza irreversível dos danos ambientais, em regra. Exemplo de sua aplicação é a exigência de estudo ambiental para o licenciamento de atividade apta a causar degradação ambiental. (AMADO, 2014, p.85).

O Superior Tribunal de Justiça (STJ) já decidiu neste sentido, no Recurso Especial (Resp) 647.493/SC, tendo como relator o Ministro João Otávio de Noronha, publicado no Dje em 22/10/2007 (in verbis), ao definir que a responsabilidade da União era subjetiva com vista na omissão faute du service.

RECURSO ESPECIAL. AÇÃO CIVIL PÚBLICA. POLUIÇÃO AMBIENTAL. EMPRESAS MINERADORAS. CARVÃO MINERAL. ESTADO DE SANTA CATARINA. REPARAÇÃO. RESPONSABILIDADE DO ESTADO POR OMISSÃO. RESPONSABILIDADE SOLIDÁRIA. RESPONSABILIDADE SUBSIDIÁRIA.

A responsabilidade civil do Estado por omissão é subjetiva, mesmo em se tratando de responsabilidade por dano ao meio ambiente, uma vez que a ilicitude no comportamento omissivo é aferida sob a perspectiva de que deveria o Estado ter agido conforme estabelece a lei. 2. A União tem o dever de fiscalizar as atividades concernentes à extração mineral, de forma que elas sejam equalizadas à conservação ambiental. Esta obrigatoriedade foi alçada à categoria constitucional, encontrando-se inscrita no artigo $225, \S \S 1^{\circ}, 2^{\circ}$ e $3^{\circ}$ da Carta Magna. 3. Condenada a União a reparação de danos ambientais, é certo que a sociedade mediatamente estará arcando com os custos de tal reparação, como se fora auto-indenização. Esse desiderato apresenta-se consentâneo com o princípio da equidade, uma vez que a atividade industrial responsável pela degradação ambiental- por gerar divisas para o país e contribuir com percentual significativo de geração de energia, como ocorre com a atividade extrativa mineral- a toda a sociedade beneficia. 4. Havendo mais de um causador de um mesmo dano ambiental, todos respondem solidariamente pela reparação, na forma do art. 942 do Código Civil. De outro lado, se diversos forem os causadores da degradação ocorrida em diferentes locais, ainda que contíguos, não há como atribuir-se a responsabilidade solidária adotando-se apenas o critério geográfico, por falta de nexo causal entre o dano ocorrido em um determinado lugar por atividade poluidora realizada em outro local. 5. A desconsideração da pessoa jurídica consiste na possibilidade de se ignorar a personalidade jurídica autônoma da entidade moral para chamar à responsabilidade seus sócios ou administradores, quando utilizam-na com objetivos fraudulentos ou diversos daqueles para os quais foi constituída. Portanto, (i) na falta do elemento "abuso de direito"; (ii) não se constituindo a personalização social obstáculo ao cumprimento da obrigação de reparação ambiental; e (iii) nem comprovando-se que os sócios ou administradores têm maior poder de solvência que as sociedades, a aplicação da disregard doctrine não tem lugar e pode constituir, na última hipótese, obstáculo ao cumprimento da obrigação. 6 . Segundo o que dispõe o art. $3^{\circ}$, IV c/c o art. $14, \S 1^{\circ}$, da Lei $n^{\circ} 6.938 / 81$, os sócios/administradores respondem pelo cumprimento da obrigação de reparação ambiental na qualidade de 
responsáveis em nome próprio. A responsabilidade será solidária. 7. A ação de reparação/recuperação ambiental é imprescritível. 8. Recursos de Companhia Siderúrgica Nacional, Carbonífera Criciúma S/A, Carbonífera Metropolitana S/S, Carbonífera Barro Branco S/S, Carbonífera Palermo Ltda., Ibramil- Ibracoque Mineração Ltda.não-conhecidos. Recurso da União provido em parte. Recursos de CoqueCatarinense Ltda., Companhia Brasileira Carbonífera de Ararangua (massa falida), Companhia Carbonífera Catarinense, Companhia Carbonífera Urussanga providos em parte. Recurso do Ministério Público provido em parte. (STJ- REsp: 647493 SC 2004/0032785-4, Relator: Ministro João Otávio de Noronha, Data de Julgamento: 22/05/2007, T2- Segunda Turma, Data de Publicação: DJ 22/10/2007 p.233).

Prosseguindo, o acórdão restou ementado da seguinte forma:

ADMINISTRATIVO. CONSTITUCIONAL. AÇÃO CIVIL PÚBLICA. MEIO AMBIENTE. MINERAÇÃO. DANOS CAUSADOS. INDENIZAÇÃO. RESPONSABILIDADE OBJETIVA DO POLUIDOR. RESPONSABILIDADE SUBJETIVA DA UNIÃO.

I Inocorrência de cerceamento pelo indeferimento de prova, porquanto a responsabilidade do poluidor é objetiva, prescindindo de prova de culpa, constituindo-se o dano e o nexo causal fatos notórios conforme elementos comprobatórios encartadas nos autos do inquérito civil público. II Incidência do art. 1.518 do Código Civil que consagra a responsabilidade solidária dos causadores do dano. Possibilidade de regresso com fulcro no art. 1.524 do Código Civil.

III A responsabilidade civil da União na espécie segue a doutrina da responsabilidade subjetiva, traduzida na omissão "faute du service". Hipótese em que provada a ineficiência do serviço fiscalizatório. Responsabilidade solidária do ente estatal com o poluidor. IV Reconhecimento da improcedência da ação em relação ao Estado de Santa Catarina pois, anteriormente à Constituição Federal de 1988, a competência administrativa em relação às jazidas, minas e demais recursos minerais era privativa da União Federal, nos termos do artigo 168 da CF/67. A norma inserida na Lei $\mathrm{n}^{\circ} 6.938 / 81$ conferindo competência ambiental aos Estados-membros deve ser interpretada em consonância com a Constituição.

Hipótese em que restou comprovado que após 1988, o Estado de Santa Catarina, através da FATMA, teve intensa atuação em prol do meio ambiente. V Não estando consagrada expressamente na lei vigente à época dos fatos a teoria da desconsideração da personalidade jurídica independe de culpa dos sócios das empresas, a improcedência da ação em relação aos sócios é medida que se impõe em face da ausência de prova de culpa lato sensu. VI Improcedência da ação em relação à ré Nova Próspera S.A. pela aplicabilidade da Lei das Sociedades Anônimas que em seu artigo 233, parágrafo único, dispõe sobre a responsabilidade única do vencedor quando afastada a solidariedade através de contrato. (STJ- REsp: 647493 SC 2004/0032785-4, Relator: Ministro João Otávio de Noronha, Data de Julgamento: 22/05/2007, T2- Segunda Turma, Data de Publicação: DJ 22/10/2007 p.233).

Entretanto, o mesmo Tribunal decidiu em sentido contrário no Recurso Especial 1.071.741, tendo como relator o Ministro Herman Benjamin, publicado no Dje em 16/12/2010:

Logo, o ente público é solidária, objetiva e ilimitadamente responsável, nos termos da Lei 6.938/1981, por danos ambientais e urbanísticos que venha, 
"direta ou indiretamente", a causar. Na opinião do relator, a situação é mais singela quando o próprio Poder Público, por atuação comissiva, causa materialmente a degradação, p. ex., ao desmatar ilegalmente Área de Preservação Permanente. É imputação por ato próprio. Embora menos comum, continua o ministro, não difere muito, no essencial, a coresponsabilidade do Estado decorrente da omissão do seu dever de controlar e fiscalizar a integridade do meio ambiente ecologicamente equilibrado, na medida em que contribua, direta ou indiretamente, tanto para a degradação ambiental em si mesma, como para o seu agravamento, consolidação ou perpetuação, tudo sem prejuízo da adoção, contra o agente público relapso ou desidioso, de medidas disciplinares, penais, civis, inclusive no que se refere à improbidade administrativa. (Resp 1.071.741, relado pelo Ministro Herman Benjamin, publicado no Dje em 16/12/2010 apud. DINIZ; MIRANDA, 2014, p.07).

Nesta linha, há uma presunção de culpa do Estado,

O lesado não precisa fazer prova de que existiu a culpa ou dolo. Ao Estado é que cabe demonstrar que agiu com diligência, que utilizou os meios adequados e disponíveis e que, se não agiu, é porque sua atuação estaria acima do que seria razoável exigir; se fizer essa demonstração, não incidirá a responsabilidade. (DI PIETRO, 2017, p. 828).

Apesar da divergência existente na doutrina e no judiciário, atualmente prevalece a tese da responsabilidade objetiva do Estado nos casos de omissão fiscalizatória, ou seja, não há a necessidade de demonstração de culpa.

\section{CONCLUSÃO}

Após análise das fontes bibliográficas podemos destacar que há, como já supracitado, divergência na jurisprudência no que tange à subjetividade - ou objetividade - da responsabilidade civil do Estado em decorrência de danos ambientais motivados por terceiros, sob omissão fiscalizatória do mesmo. Não se pode negar, porém, a força normativa da Carta Magna, que expressamente impõe ao Poder Público o dever legal de defender o meio ambiente equilibrado.

Em matéria de Direito Civil, entende-se completamente possível a responsabilidade derivada de conduta omissiva, em caso de dever legal de cuidado. Tendo sido explícito o dever legal de preservação imposto ao Estado, é elementar compreender como possível a aplicação de responsabilidade objetiva do Estado por danos ambientais causados por terceiros, sempre que houver nexo de causalidade entre o referido dano e a omissão fiscalizatória estatal.

Cumpre-se observar, ainda, a possibilidade de ação de regresso da União contra o terceiro causador do dano. 


\section{REFERÊNCIAS}

AMADO, Frederico Augusto Di Trindade. Direito Ambiental Esquematizado. $5^{\mathrm{a}}$ ed. Rio de Janeiro: Forense; São Paulo: Método, 2014.

BRASIL. [Constituição (1988)]. Constituição da República Federativa do Brasil. Brasília, DF: Presidência da República, [2016]. Disponível em:

http://www.planalto.gov.br/ccivil_03/Constituicao/Constituicao.htm. Acesso em: 09 maio 2019.

BRASIL. Lei $\mathbf{n}^{\circ}$ 9.605, de 12 de fevereiro de 1998. Dispõe sobre as sanções penais e administrativas derivadas de condutas e atividades lesivas ao meio ambiente, e dá outras providências. Disponível em: http://www.planalto.gov.br/ccivil_03/leis/L9605.htm. Acesso em: 23 set. 2019.

BRASIL. Lei $\mathbf{n}^{0}$ 6.938, de 31 de agosto de 1981. Dispõe sobre a Política Nacional do Meio Ambiente, seus fins e mecanismos de formulação e aplicação, e dá outras providências. Disponível em: http://www.planalto.gov.br/ccivil_03/leis/16938.htm. Acesso em: 10 maio 2019.

BRASIL. Lei no 10.406, de 10 de janeiro de 2002. Institui o Código Civil. Disponível em: http://www.planalto.gov.br/ccivil_03/leis/2002/110406.htm. Acesso em: 09 maio 2019.

BRASIL. Superior Tribunal de Justiça. Recurso Especial n 647.493/SC. Administrativo. Constitucional. Ação Civil Pública. Meio Ambiente. Mineração. Danos causados. Indenização. Responsabilidade objetiva do poluidor. Responsabilidade subjetiva da União. Relator Ministro João Otávio de Noronha, 22 de outubro de 2007. Disponível em: https://stj.jusbrasil.com.br/jurisprudencia/19221820/recurso-especial-resp-647493-sc-20040032785-4-stj/relatorio-e-voto-19221822?ref=juris-tabs. Acesso em: 23 set. 2019.

BRASIL. Superior Tribunal de Justiça. Recurso Especial n 647.493/SC. Recurso Especial. Ação Civil Pública. Poluição Ambiental. Empresas Mineradoras. Carvão Mineral. Estado de Santa Catarina. Reparação. Responsabilidade do Estado por Omissão. Responsabilidade Solidária. Responsabilidade Subsidiária. Relator Ministro João Otávio de Noronha, 22 de outubro de 2007. Disponível em: https://stj.jusbrasil.com.br/jurisprudencia/19221820/recursoespecial-resp-647493-sc-2004-0032785-4-stj/relatorio-e-voto-19221822?ref=juris-tabs. Acesso em: 23 set. 2019.

DI PIETRO, Maria Sylvia Zanella. Direito Administrativo. $30^{\mathrm{a}}$ ed. Rio de Janeiro: Forense, 2017.

DINIZ, Cirlene; MIRANDA, Sandra de Mello Carneiro. Responsabilidade do Estado por danos ambientais decorrentes da omissão do Poder Público no exercício do poder de polícia. Disponível em: http://www.publicadireito.com.br/artigos/?cod=0a94234e0f6cc541. Acesso em: 10 maio 2019.

PINTO, Cristiano Vieira Sobral. Direito Civil Esquematizado. 10 a ed. Salvador: Juspodivm, 2018.

SILVA, Solange Teles da. Responsabilidade Civil Ambiental. PHILIPPI JR, Arlindo; ALVES; Alaôr Caffé. Curso Interdisciplinar de Direito Ambiental. Barueri: Manole, 2005. 
TARTUCE, Flávio. Direito Civil: direito das obrigações e responsabilidade civil. $12^{\mathrm{a}}$ ed. Rio de Janeiro: Forense, 2017.

THOMÉ, Romeu. Manual de direito ambiental. 9ª ed. Salvador: Juspodivm, 2019.

VOLANTE, Carlos Eduardo. A responsabilidade civil do Estado por dano ambiental decorrente da omissão fiscalizatória. Revista Acadêmica de Direitos Fundamentais, Osasco, 2012, ano 6, n.6. Disponível em: http://www.egov.ufsc.br:8080/portal/sites/default/files/7272284-1-pb.pdf. Acesso em: 09 maio 2019. 


\section{A CONSTITUCIONALIDADE DO TETO REMUNERATÓRIO NOS CASOS DE ACUMULAÇÃO LÍCITA DE CARGOS PÚBLICOS NO BRASIL}

The wage cap's constitutionality in the lawful cases of public offices accumulation in Brazil.

\section{Danilo Vieira Vilela}

Professor efetivo da Universidade do Estado de Minas Gerais (UEMG). Doutor em Direito Político e Econômico pela Universidade Presbiteriana Mackenzie (Bolsista Mackenzie). Mestre em Direito Obrigacional Público e Privado pela Universidade Estadual Paulista Júlio de Mesquita Filho UNESP (Bolsista FAPESP), Especialista em Direito Processual (UEMG), Especialista em Direito Penal e Processual Penal (UCDB), Especialista em Direito Empresarial e Advocacia Empresarial (Anhanguera-Uniderp) e MBA em Gestão Empresarial (UNESC). Professor em cursos de pósgraduação e em cursos preparatórios para concursos. Advogado e Árbitro no CBLE - Centro Brasileiro de Litígios Econômicos. E-mail: danilo.vilela@uemg.br

\section{Ana Beatriz do Amaral Souza}

Pesquisadora bolsista em Iniciação Científica do Programa de Apoio à Pesquisa - PAPq/UEMG nos anos de 2017, 2018 e 2019. Graduação em Direito em andamento pela Universidade do Estado de Minas Gerais - UEMG/ Frutal. Teve atuação como estagiária da Defensoria Pública do Estado de Minas Gerais no ano de 2019. Interessa-se por temas que versam sobre Direito Constitucional, Direitos Humanos, Direito Penal, Inclusão Social de Minorias e Grupos Vulneráveis. E-mail: anabasouza@yahoo.com.br

\section{Rafaella Pereira Frujuelle}

Pesquisadora bolsista em Iniciação Científica do Programa de Apoio à Pesquisa - PAPq/UEMG. Graduação em Direito em andamento pela Universidade do Estado de Minas Gerais- UEMG/Frutal. Já atuou com estagiária em órgão publico do poder executivo, bem como em escritórios de advocacia. Interessa-se por temas que versam sobre o Direito Empresarial, principalmente nos institutos de Falência e Recuperação Judicial, como também por Direito Administrativo e Direito Constitucional.

Resumo: O texto constitucional em vigor no Brasil estabelece, como regra, a impossibilidade da acumulação de cargos na Administração Pública Direta ou Indireta, fixando, expressamente, as exceções. Entretanto, até o presente não foi pacificado o entendimento acerca da limitação na quantidade de horas de trabalho do servidor público que licitamente acumula cargos, carecendo, portanto, de lei para suprir mencionada lacuna. Além das hipóteses de acumulação, outro ponto tem chamado atenção da doutrina e da jurisprudência é a aplicabilidade da regra do teto remuneratório aos servidores que acumulam, licitamente, tais cargos. Historicamente a jurisprudência brasileira vinha se mostrando favorável à aplicação da regra do teto, considerando-se, cumulativamente os cargos ocupados. Contudo, entendimentos recentes dos tribunais superiores, assim como do Tribunal de Contas da União apontam para sentido diverso. Assim, o presente trabalho tem por objetivo analisar as hipóteses constitucionais de acumulação de cargos públicos e, a partir disso, identificar a mudança do entendimento da jurisprudência pátria no sentido de se aplicar a cada um dos cargos, separadamente, os critérios estabelecidos no art. 37, XI, da Constituição da República, para o teto remuneratório. Parte-se de uma pesquisa documental e bibliográfica, utilizando-se como fontes principais julgados de tribunais brasileiros e decisões do Tribunal de Contas da União para, através de um método dedutivo, demonstrar as incertezas quanto à limitação de horas no caso de acúmulo de cargos públicos, assim como a evolução do entendimento referente à incidência do teto remuneratório constitucional nos casos de acumulação lícita de cargos. 
Palavras-chave: servidores públicos; acumulação de cargos públicos; teto remuneratório; princípio da eficiência.

\begin{abstract}
The constitutional text in force in Brazil establishes, as a general rule, the impossibility of accumulating positions in the Direct or Indirect Public Administration, expressing, though, some exceptions. However, untill now, it has not been pacified the understanding regarding the limitation on the workload of public service employees, who lawfully accumulate ublic offices, once the law needs to fill this loophole on this matter. Besides, another matter that has drawn attention from doctrine and jurisprudence is the applicability of the wage cap rule to ublic service employees who have legally accumulated those positions. Historically, brazilian jurisprudence has been favorable to the application of the wage cap in these terms, considering cumulatively the positions held. However, recent understandings from the higher courts, as well as from the Union's Court of Auditors, point to a different direction. Thus, this paper aims to analyze the constitutional hypotheses of accumulation of public offices and, so, to identify the modification in the court's understanding on this matter, in order to apply to each of the positions, separately, the criteria established in art. 37, XI, of the Constitution of the Republic, for the wage cap. It starts with a documentary and bibliographical research, using as main sources judicial decisions from brazilian courts and from the Court of Auditors to, by means of a deductive method, demonstrate the uncertainties regarding the limitation of workload in case of offices accumulation, as well as the progress of the understanding regarding the incidence of the constitutional wage cap in case of licit offices accumulation.
\end{abstract}

Keywords: Public service employees; Public offices accumulation; Wage cap; Principle of efficiency.

\title{
INTRODUÇÃO
}

Visando impedir abusos historicamente presentes na Administração Pública, e privilegiar a eficiência no trato da res publica, a Constituição da República Federativa do Brasil, de 1988, fixou uma série de regras no sentido de limitar as possibilidades de ocupação de cargos públicos.

Nesse sentido, uma das principais limitações diz respeito à acumulação de cargos. Assim, considerando a necessidade de que o servidor se dedique, profissionalmente, ao cargo que ocupa, o texto constitucional estabeleceu como regra a impossibilidade de que uma pessoa ocupe, ao mesmo tempo, mais que um cargo na Administração Pública Direta ou Indireta. Contudo, a própria Constituição fixou exceções à regra, permitindo o acúmulo em situações específicas, geralmente voltadas à combinação de uma função técnica com a docência, o que alcança, inclusive, magistrados e membros do Ministério Público e, mais recentemente, em 
razão da Emenda Constitucional n 101/2019, militares dos Estados, do Distrito Federal e dos Territórios.

Ante a licitude do acúmulo de determinados cargos, questão que se apresenta diz respeito à quantidade de horas que o servidor poderia se dedicar a cada uma das funções, considerando-se o razoável para permitir ao indivíduo descansar devidamente, de forma a não prejudicar a atividade desempenhada.

Nesse ponto, a ausência de uma lei específica para disciplinar o tema conduz a incertezas em razão da insegurança jurídica resultante de divergências entres os tribunais superiores, Tribunal de Contas da União e Advocacia-Geral da União. Contudo, recentes decisões e a revogação do Parecer GQ-145 da AGU parecem indicar que a quantidade de horas resultantes da acumulação per si não é suficiente para impedir o acúmulo.

Por outro lado, superada a análise da possibilidade da acumulação dos cargos públicos, o presente trabalho visa analisar a constitucionalidade da imposição do limite remuneratório às situações de acúmulo lícito. Para tanto, são analisados os entendimentos dos principais tribunais para, ao final, evidenciar a tendência absolutamente majoritária na atualidade, de que para efeitos da incidência do teto deva-se considerar cada um dos cargos de maneira individualizada. Além da análise jurisprudencial, que justifica o emprego do método dedutivo, a presente pesquisa utiliza-se da doutrina administrativista, desde autores clássicos e consagrados como José dos Santos Carvalho Filho e Maria Syvia Zanella Di Pietro, até autores de destaque a nova geração do Direito Administrativo, como Irene Patrícia Nohara e Rafael Carvalho Rezende Oliveira.

\section{A CONSTITUCIONALIDADE DA ACUMULAÇÃO DE CARgOS PÚBLICOS NO DIREITO BRASILEIRO}

Como regra, o texto constitucional de 1988 veda a acumulação remunerada de cargos, empregos ou funções na Administração Pública, proibição que alcança também autarquias, fundações, empresas estatais, suas subsidiárias e as sociedades controladas, direta ou indiretamente, pelo Poder Público (art. 37, XVI e XVII da CRFB/88).

Em relação à acumulação não remunerada de cargos, a doutrina majoritariamente entende não haver vedação desde que, mesmo nesses casos, haja compatibilidade de horários entres os cargos "sob pena de admitir o exercício ineficiente da função pública, o que violaria o princípio constitucional da eficiência e as exigências legais de desempenho inerentes á função exercida" (OLIVEIRA,2017, p. 699-700). 
Assim, pautada pelos princípios da moralidade e da eficiência administrativa, a Constituição busca evitar aquilo que a doutrina chama de "funcionários 'turistas' ou até os vulgarmente chamados 'fantasmas', que se enriquecem ilicitamente com a remuneração paga pelos cofres públicos sem oferecer a contrapartida funcional” (NOHARA, 2019, p. 764-765).

Por outro lado, é o próprio texto constitucional que acaba por excepcionar expressamente a regra da não acumulação, ao fixar que: "é vedada a acumulação remunerada de cargos públicos, exceto, quando houver compatibilidade de horários, observado em qualquer caso o disposto no inciso IX" (teto remuneratório): a) a de dois cargos de professor; b) a de um cargo de professor com outro, técnico ou científico; c) a de dois cargos ou empregos privativos de profissionais de saúde, com profissões regulamentadas.

Há que se destacar que, em julho de 2019 a Emenda Constitucional $n^{\circ} 101$ estendeu aos militares dos Estados, do Distrito Federal e dos Territórios o disposto no art. 37, inciso XVI, com prevalência da atividade militar.

Merece destaque o entendimento de Maria Sylvia Zanella Di Pietro, segundo a qual "as exceções somente admitem dois cargos, empregos ou funções, inexistindo qualquer hipótese de tríplice acumulação, a não ser que uma das funções não seja remunerada" (DI PIETRO, 2017, p. 722).

Além destas exceções, a Constituição da República também admite outros dois casos de acumulação, quais sejam, de juízes (art. 95, parágrafo único, I) e membros do Ministério Público (art. 128, §5 , II, d) que podem exercer, cumulativamente ao cargo, uma função de magistério 5 .

Observe-se, contudo, que qualquer que seja a hipótese de acumulação lícita de cargos púbicos, há que se analisar a compatibilidade de horários. Entretanto, a compreensão da expressão "compatibilidade de horários" tem ensejado intensos debates tanto na doutrina quanto na jurisprudência, uma vez que não há na lei uma delimitação de carga horária máxima de trabalho para servidores públicos.

No anseio de estabelecer um parâmetro, a doutrina parte do princípio da eficiência, previsto na Constituição Federal, apresentando-o como um limite implícito. Segundo José dos Santos Carvalho Filho,

É mister que os sujeitos da atividade tenham qualificação compatível com as funções a seu cargo. Indiscutível, pois, o rigor com que se deve haver a Administração para o recrutamento de seus servidores. Quando estes possuem qualificação, escolhidos que foram pelo sistema do mérito, as atividades da

\footnotetext{
${ }^{5}$ Nesse ponto, segundo entendimento majoritário da doutrina, “a norma é mais restritiva para o juiz do que para o promotor público; o primeiro, além das funções de seu cargo, só pode exercer uma função de Magistério, seja pública ou privada; o Promotor Público pode exercer outra função pública de magistério, nenhuma restrição havendo quanto ao magistério particular". (DI PIETRO, 2017, p. 723). 
Administração são exercidas com maior eficiência. (CARVALHO FILHO, 2018, p. 120)

Dessa forma, entende-se que, para não prejudicar a Administração, é indispensável a qualificação adequada do servidor público para a função que desempenhará. Isso se dá porque, conforme expõe Irene Patrícia Nohara “o princípio da eficiência impõe ao agente público um modo de atuar que produza resultados favoráveis à consecução de fins que cabem ao Estado alcançar" (2019, p. 93).

Em complemento, Hely Lopes Meirelles preceitua que

O princípio da eficiência exige que a atividade administrativa seja exercida com presteza, perfeição e rendimento funcional. É o mais moderno princípio da função administrativa, [...] exigindo resultados positivos para o serviço público e satisfatório atendimento das necessidades da comunidade e de seus membros. (MEIRELLES, 2008, p. 96-97)

Com base nesse entendimento, a Advocacia Geral da União, através do Parecer Administrativo $\mathrm{n}^{\circ}$ GQ-145 limitou em 60 horas semanais a atividade de servidores públicos, ainda que sem situações de acumulação lícita de cargos.

Nesse sentido, em consonância com o entendimento da AGU e buscando preservar a eficiência na atuação do servidor público, o Tribunal de Justiça de Minas Gerais também decidiu contrariamente a que ocupantes de cargos públicos ultrapassem a carga horária estabelecida de 60 horas, já que a sobrecarga de trabalho torna impossível o adequado descanso, e, consequentemente, prejudica a destreza no desempenho da atividade laboral Nesse sentido:

Apelação mandado de $\quad$ de
servidor público - acumulação de cargos - decadência - inocorrência

Esse tradicional entendimento da AGU, reproduzido pelo Tribunal de Justiça de Minas Gerais também vem sendo adotado pelo Tribunal de Contas da União (TCU) e, mais 
recentemente, pelo Superior Tribunal de Justiça, que, por sua vez, chegou a publicar a seguinte tese: “A limitação da carga horária semanal para servidores públicos profissionais de saúde que acumulam cargos deve ser de 60 horas semanais".

Contudo, essa discussão não parece estar próxima do fim. Por um lado, o Supremo Tribunal Federal vem entendendo pela possibilidade de a acumulação lícita extrapolar o limite de 60 horas, uma vez que não há tal requisito na Constituição Federal (RE 1.094.802 AgR, Relator Min. Alexandre de Moraes, Primeira Turma, julgado em 11/5/2018, DJe 24/5/2018).

Por outro lado, em abril de 2019, a Advocacia-Geral da União revogou e pediu a revisão do Parecer GQ-145, firmando a tese segundo a qual "é inválida a regulamentação administrativa que impõe limitação de carga horária semanal como empecilho para a acumulação de cargos públicos".

Conforme demonstrado, a compreensão das hipóteses de acumulação lícita de cargos públicos não é tão simples quanto parece ser em uma análise superficial do art. 37 da Constituição de 1988. Nesse sentido, partindo-se do pressuposto na necessidade de que o tema seja tratado por meio de lei, somente a atuação do Congresso Nacional poderá dar um fim a essa polêmica.

\section{O TETO REMUNERATÓRIO ANTE A POSSIBILIDADE DE ACUMULAÇÃO DE CARGOS PÚBLICOS NO BRASIL}

Além da questão relativa à fixação ou não de uma carga horária máxima, de forma a não comprometer a eficiência no exercício da função administrativa, outro ponto que merece destaque e vem sendo, também, alvo de divergência doutrinária e jurisprudencial, diz respeito à sujeição ao teto remuneratório nos casos de acumulação lícita de cargos.

Inicialmente, o texto da Constituição Federal, aprovado em 1988 estabelecia que caberia cada um dos Poderes da União, dos Estados e do Distrito Federal possuía seu próprio teto de remuneração, a ser fixado por lei, garantindo-se isonomia de vencimentos para cargos de atribuições iguais ou assemelhadas no mesmo Poder, ou entre os outros Poderes, salvo vantagens de caráter individual e relativas ao local do trabalho. Assim, foi fixado limite remuneratório, inexistente no regime constitucional anterior (MARINELA, 2014, p. 755).

No ano de 1998, a Emenda Constitucional nº 19 alterou, dentre outras, a redação original do inciso XI do art. 37, que, por sua vez, seria mais tarde novamente alterado pela EC 41/2003, contando, atualmente, com o seguinte texto: 
XI - a remuneração e o subsídio dos ocupantes de cargos, funções e empregos públicos da administração direta, autárquica e fundacional, dos membros de qualquer dos Poderes da União, dos Estados, do Distrito Federal e dos Municípios, dos detentores de mandato eletivo e dos demais agentes políticos e os proventos, pensões ou outra espécie remuneratória, percebidos cumulativamente ou não, incluídas as vantagens pessoais ou de qualquer outra natureza, não poderão exceder o subsídio mensal, em espécie, dos Ministros do Supremo Tribunal Federal, aplicando-se como limite, nos Municípios, o subsídio do Prefeito, e nos Estados e no Distrito Federal, o subsídio mensal do Governador no âmbito do Poder Executivo, o subsídio dos Deputados Estaduais e Distritais no âmbito do Poder Legislativo e o subsídio dos Desembargadores do Tribunal de Justiça, limitado a noventa inteiros e vinte e cinco centésimos por cento do subsídio mensal, em espécie, dos Ministros do Supremo Tribunal Federal, no âmbito do Poder Judiciário, aplicável este limite aos membros do Ministério Público, aos Procuradores e aos Defensores Públicos;

Dessa forma, a EC 19/98 introduziu no Brasil um teto remuneratório aplicável a todo o serviço público, equivalente ao subsídio mensal dos Ministros do Supremo Tribunal Federal, salvo a exceção contida no $\S 9^{\circ}$ do mesmo art. 37, que exclui a regra supratranscrita daquelas empresas estatais que não recebem recursos da União, dos Estados, do Distrito Federal ou dos Municípios para pagamento de despesas de pessoal ou de custeio em geral.

Assim, em relação às empresas públicas e sociedades de economia mista, o teto constitucional aplica-se apenas às chamadas estatais dependentes, quais sejam, as empresas controladas que recebam "do ente controlador recursos financeiros para pagamento de despesas com pessoal ou de custeio em geral ou de capital, excluídos, no último caso, aqueles provenientes de aumento de participação acionária" (art. 2º III, da LC 101/2000).

Tais regras do teto e respectivos subtetos abrangem todo o sistema remuneratório do servidor público, independentemente de se tratar de celetista ou estatutário, "atingindo todas as formas remuneratórias, isto é, remuneração, subsídio, proventos e outras, percebidas cumulativamente ou não, incluídas as vantagens pessoais ou de qualquer outra natureza" (MARINELA, 2014, p. 758).

Nesse sentido, durante muito tempo entendeu-se que o servidor que estivesse em regime de acumulação estaria sujeito a um teto único, de forma a abranger a soma das retribuições pecuniárias.

Ou seja, acreditava-se que "aduz constar do texto da Lei Fundamental que, tratandose de exercício simultâneo de cargos públicos, os valores percebidos, para fins de observância do teto remuneratório, devem ser considerados cumulativamente, e não de modo isolado", conforme disposto no relatório do RE 612.975/MT, devido à ideia de que essa questão deveria ser analisada a partir de um viés econômico, social, político e jurídico. 
Em sentido contrário, tanto o Conselho Nacional de Justiça (CNJ) quanto o Conselho Nacional do Ministério Público (CNMP) disciplinaram a matéria através das resoluções 13 e 14, de 2006 e 09 e 10, de 2006, respectivamente, no sentido de excluir do teto algumas verbas permanentes e/ou temporárias, tais como verbas indenizatórias e verbas decorrentes do exercício do magistério, dentre outras (MARINELA, 2014, p. 762).

Assim, em razão de tais resoluções é possível compreender que "para os magistrados o exercício cumulativo de suas atribuições com uma de magistério não impede a percepção das retribuições correspondentes aos dois cargos, ainda que sua soma supere o teto" (DI PIETRO, 2017, p. 715).

Nesse sentido, baseada no princípio da valorização do trabalho e da igualdade, a jurisprudência do Supremo Tribunal Federal (STF) estabeleceu a seguinte tese de repercussão geral:

Nos casos autorizados constitucionalmente de acumulação de cargos, empregos e funções, a incidência do art. 37, XI, da Constituição Federal pressupõe consideração de cada um dos vínculos formalizados, afastada a observância do teto remuneratório quanto ao somatório dos ganhos do agente público. STF. Plenário. RE 612975/MT e RE 602043/MT, Rel. Min. Marco Aurélio, julgados em 26 e 27/4/2017 (repercussão geral) (Info 862).

Dessa maneira, no caso de magistrado aposentado que acumula cargo de magistério reconheceu-se como indevida a retenção de parte dos seus subsídios. Embora seja este um servidor que ocupa dois cargos públicos, se faz necessário obedecer a determinações constitucionais que pressupõem a análise dos rendimentos de maneira individualizada.

$\mathrm{O}$ entendimento de que o teto remuneratório deveria ser aplicado de maneira individualizada a cada um dos cargos, em caso de acumulação lícita, passou a ganhar adeptos. Assim, não analisar os ganhos de maneira individual seria uma afronta aos direitos dos trabalhadores. No mais, por não se tratar de trabalho voluntário, seria injusto e, até mesmo, inconstitucional, não receber a devida remuneração em troca do trabalho que foi executado, como discorreu o Ministro Luís Roberto Barroso em seu voto para o RE 612.975/MT, no qual afirmou que "[...] considero que a cláusula pétrea violada aqui é o direito fundamental à remuneração pelo trabalho desempenhado".

Em recente decisão sobre o tema, o Superior Tribunal de Justiça (STJ) entendeu que os proventos devem ser analisados, em relação ao teto remuneratório, de maneira particularizada, conforme disposto no Agravo Regimental no Recurso em Mandado de Segurança 45.937/DF.

A jurisprudência desta Corte orienta-se no sentido de que em se tratando de cumulação legítima de cargos, a remuneração do servidor público não se 
submete ao teto constitucional, devendo os cargos, para este fim, ser considerados isoladamente. [...] STJ. 1 ${ }^{\text {a }}$ Turma. AgRg no RMS 45.937/DF, Rel. Min. Benedito Gonçalves, julgado em 05/11/2015.

A mudança de entendimento também vem sendo sentida nas decisões do Tribunal de Contas da União. Observe-se que até pouco tempo, o TCU entendia que nos casos de acumulação de cargos constitucionalmente aceita, a soma das remunerações deveria se ater ao teto constitucional, excetuando-se a situação de magistrados e membros do Ministério Público diante da previsão expressa. Nesse sentido:

No exercício de dois cargos públicos, as acumulações previstas no art. 37, inciso XVI, da Constituição Federal se submetem ao teto pelo somatório das respectivas remunerações. Em outras hipóteses de acumulação expressamente admitidas pelo texto constitucional, como as de magistrados com assento nos tribunais eleitorais (arts. 119 e 120) ou as de juízes e professores (art. 95, parágrafo único, inciso I), o teto remuneratório deverá ser observado de forma isolada para cada um dos cargos acumulados na atividade. (Plenário. Representação. Processo 030.632/2007-5. Acórdão 1994/2015. Rel. Min. Benjamin Zymler) (grifo nosso).

Contudo, mais recentemente, em 2018, o Plenário do TCU mudou seu entendimento e passou a admitir que:

[...] o servidor público faz jus a receber concomitantemente vencimentos ou proventos decorrentes de acumulação de cargos autorizada pelo art. 37, inciso XVI, da Constituição Federal, estando ou não envolvidos entes federados, fontes ou Poderes distintos, ainda que as soma resulte em montante superior ao teto especificado no art. 37, inciso XI, da CF, devendo incidir o referido limite constitucional sobre cada um dos vínculos per si, assim considerados de forma isolada, com contagem separada para fins de teto vencimental. (Plenário. Consulta. Processo no TC 000.776/2012-2. Acórdão no 501/2018. Rel. Min. Benjamin Zymler).

Assim, o TCU unifica seu entendimento com os Tribunais Superiores, tendo como fundamento o princípio da isonomia, de forma que o exercício de cargos iguais não poderia resultar em remunerações diferentes; da dignidade do valor do trabalho e da vedação do trabalho gratuito.

\section{CONCLUSÃO}

O teto remuneratório diz respeito ao maior valor que poderá ser pago a um indivíduo para o desempenho de determinada função pública. No Brasil, esse montante máximo é definido de acordo com o subsídio dos Ministros do Supremo Tribunal Federal, e não pode ser excedido, conforme previsto constitucionalmente (art. 37, XI). 
No que tange ao acúmulo de funções públicas, somente são autorizadas pelo texto constitucional, caso haja correspondência de horários, dois cargos de professor, um de professor com outro técnico ou científico, ou dois cargos privativos de profissionais da saúde.

Até pouco tempo, entendia-se que o provento de quem acumulava funções públicas deveria ser analisado, com relação ao teto salarial, de maneira conjunta. Assim, a soma de ambas as remunerações não poderia ultrapassar a dos membros do STF.

Contudo, conforme restou evidenciado no presente trabalho, esse entendimento foi superado. Hoje, os tribunais superiores (STF e STJ) assim como o Tribunal de Contas da União, adotam o entendimento no sentido de que deve ser realizada uma averiguação dos ganhos por cada emprego público de maneira isolada.

Assim, a questão da constitucionalidade do teto remuneratório nos casos de acumulação lícita de cargos públicos no Brasil parece estar pacificada, considerando a recente fixação de entendimentos da cúpula do Poder Judiciário nacional.

Entretanto, apesar disso, há que se destacar a urgente necessidade de se apontar uma solução no que diz respeito à limitação da quantidade de horas de trabalho daqueles servidores que acumulam cargos públicos. Tal solução, imprescindível para trazer segurança jurídica aos milhares de servidores públicos atuantes em todas as esferas do Estado brasileiro, deverá, necessariamente, tomar como ponto de partida o princípio da eficiência, constitucionalmente consagrado com a EC 19/98.

Nesse sentido, o acúmulo lícito de cargos públicos não pode resultar na sobrecarga do profissional, do que resultaria, além de problemas de ordem pessoal, restrições no exercício das funções, causando prejuízos diretos e indiretos aos cofres públicos.

\section{RFERÊNCIAS}

BRASIL. Constituição (1988). Constituição da República Federativa do Brasil. 43. ed. São Paulo: Saraiva, 2014.

BRASIL. Lei $\mathbf{n}^{\mathbf{0}}$ 8.429, de 02/06/1992. Dispõe sobre o as sanções aplicáveis aos agentes públicos nos casos de enriquecimento ilícito no exercício de mandato, cargo, emprego ou função na administração pública direta, indireta ou fundacional. Disponível em: http://www.planalto.gov.br/ccivil_03/LEIS/L8429.htm. Acesso em: 12 abr. 2019. BRASIL. Superior Tribunal de Justiça. BRASIL. Supremo Tribunal Federal. Recurso Extraordinário no 612.975/MT. Recte: Estado de Mato Grosso. Recdo: Isaac Nepomuceno Filho. Relator: Ministro Marco Aurélio. Incidência do Teto Remuneratório no Caso de Acumulação de Cargos Públicos. Brasília, data de julgamento: 27 abr. 2017. Disponível em: 
http://www.stf.jus.br/portal/processo/verProcessoPeca.asp?id=312672762\&tipoApp=.pdf. Acesso em: 02 maio 2019.

BRASIL. Supremo Tribunal Federal (1. Turma). Agravo Regimental no Recurso Extraordinário 1.094.802/PE. Administrativo. Processual civil. Acumulação de cargos. Enfermagem. Carga horária superior às 60 (sessenta) horas semanais. Compatibilidade de horários a ser verificada caso a caso. Precedentes deste TRF5 e do STF. Apelação e remessa oficial desprovidas. Agravante: Empresa Brasileira de Serviços Hospitalares - EBSERH. Relator: Min. Alexandre de Moraes, 11 de maio de 2018. Disponível em: www.stf.jus.br/portal/processo/verProcessoPeca.asp?id=314421925\&tipoApp=.pdf. Acesso em: 31 ago. 2019.

BRASIL. Tribunal de Contas da União. Representação. TC 030.632/2007-5. Acórdão 1994/2015. Plenário. Extrapolação do limite remuneratório constitucional em situações de acumulação lícita de cargos públicos. Interessado: Ministério Público junto ao Tribunal de Contas da União. Rel. Min. Benjamin Zymler. 12 de agosto de 2015. Disponível em: https://pesquisa.apps.tcu.gov.br/\#/documento/acordaocompleto/*/NUMACORDAO:1994\%20ANOACORDAO:2015\%20COLEGIADO:\%22Plen $\%$ C3\%A1rio\%22/DTRELEVANCIA\%20desc, \%20NUMACORDAOINT\%20desc/0/\%20 Acesso em 24 set. 2019.

BRASIL. Tribunal de Contas da União. Consulta. Processo no TC 000.776/2012-2. Acórdão no 501/2018. Plenário. Incidência do teto remuneratório previsto no inciso XI do artigo 37 da CF/1988 em relação à percepção cumulativa de vencimentos e/ou proventos decorrentes de dois cargos públicos ainda que envolvidas esferas de governo ou poderes distintos. Rel. Min. Benjamin Zymler. 14 de março de 2018. Disponível em:

https://portal.tcu.gov.br/imprensa/noticias/tcu-segue-orientacao-do-stf-na-analise-do-tetoremuneratorio.htm Acesso em 24 set. 2019.

CARVALHO FILHO, José dos Santos. Manual de direito administrativo. 32. ed. São Paulo: Atlas, 2018.

DI PIETRO, Maria Sylvia Zanella. Direito Administrativo. 30.ed. Rio de Janeiro: Forense, 2017.

MARINELA, Fernanda. Direito Administrativo. 8.ed. Niterói: Impetus, 2014.

MEIRELLES, Hely Lopes. Direito Administrativo Brasileiro: a atividade administrativa: moralidade e eficiência. 34. ed. São Paulo: Malheiros, 2008.

MINAS GERAIS. TJMG. Apelação Cível no 5006386-56.2018.8.13.0433 (1). Apelante: Maria Lucia Santos Alves. Apelado: Município de Montes Claros. Relator: Des. Marcelo Rodrigues. Acumulação de função de enfermeira em duas instituições públicas. Belo Horizonte, data de julgamento: 12 mar. 2019. Disponível em:

https://www5.tjmg.jus.br/jurisprudencia/pesquisaNumeroCNJEspelhoAcordao.do?numeroRe gistro $=1 \&$ totalLinhas $=1 \&$ linhasPorPagina $=10 \&$ numeroUnico=1.0000.18.1425976\%2F001\&pesquisaNumeroCNJ=Pesquisar. Acesso em: 02 maio 2019.

NOHARA, Irene Patrícia. Direito Administrativo. 9. ed. São Paulo: Atlas, 2019. 
OLIVEIRA, Rafael Carvalho Rezende. Curso de Direito Administrativo. 5.ed. São Paulo: Método, 2017. 


\title{
DIREITO DO CONSUMIDOR: A INDENIZAÇÃO POR DANO MORAL NAS RELAÇÕES DE CONSUMO VIRTUAIS
}

\author{
Consumer Law: Indemnity for moral damage in virtual consumer relations
}

\section{Tamires Eduarda Santos}

\begin{abstract}
Graduação em Direito em andamento pela Universidade do Estado de Minas Gerais-UEMG/Frutal; Formada em Técnico em Química pelo Instituto Federal de São Paulo-IFSP. Atua como estagiária de Direito em escritório de advocacia. Interessa-se por temas que versam sobre Direitos Humanos, Direito Civil, Direito de Família, Estatuto da Criança e do Adolescente e Direito Penal, com experiências em pesquisas e publicações. E-mail: tamires_eduarda@yahoo.com.br
\end{abstract}

Rafaella Tôrres Vitoi

Graduação em Direito em andamento pela Universidade do Estado de Minas Gerais-UEMG/Frutal. Interessa-se por temas que versam sobre Teoria Geral do Direito. E-mail: rafaellatorresvitoi@hotmail.com

Pablo Martins Bernardi Coelho

Professor Adjunto do curso de Direito da Universidade do Estado de Minas Gerais - UEMG. Professor do curso de Direito da Faculdade Presidente Antônio Carlos - UNIPAC/Uberlândia. Doutor e Mestre em História pela Universidade Estadual Paulista "Júlio de Mesquita Filho"UNESP. Especialização em Direito Público Aplicado em andamento pela Escola Brasileira de Direito (EBRADI). Graduado em História (UNESP), Direito (UNIRP) e Ciências Sociais (UNESP). Atua principalmente nos seguintes temas: Direito Constitucional, Direito Administrativo, Direito Eleitoral, Municipal e Ciência Política. Participa como membro da ALACIP (Associação Latino Americana de Ciência Política). Pesquisador do Laboratório Americano de Estudos Constitucionais Comparados e líder do grupo de pesquisa Cultura, Direito \& Sociedade da UEMG. É avaliador MEC inserido no Banco de Avaliadores (BASis) do Sistema Nacional de Avaliação da Educação Superior (Sinaes) para os cursos de Direito. E-mail: pablo.coelho@uemg.br

Resumo: Diante da evolução da informática e todas as inovações que foram subsequentes à mesma, as relações de consumo sofreram alteração conjuntamente nas últimas décadas. Nesse sentido, as lojas virtuais não estão excluídas de ocasionar danos para a parte hipossuficiente do negócio jurídico, ou seja, o consumidor. Pelo grande crescimento desse tipo de comércio, consequentemente, as reclamações nos últimos anos vêm aumentando na mesma proporção que o número do crescimento das vendas virtuais. Assim, o Direito, instrumento que normatiza a sociedade, deve acompanhar as mudanças tecnológicas e o perfil do consumo da população para que esteja preparado para as necessidades da sociedade atual no âmbito jurídico. Desse modo, tal projeto por meio de pesquisas a jurisprudências, doutrinas e da própria legislação (Código Civil e Código de Defesa do Consumidor) visa a análise da concessão da indenização por danos morais nos casos das compras feitas por e-commerce. Para as empresas e lojas online tal amparo jurídico ao consumidor também possibilita uma maior confiança na realização dos negócios, já que se tem uma garantia palpável. Com isso, a partir do presente trabalho, é importante ressaltar a necessidade de uma regulamentação voltada para o meio virtual e a aplicação da indenização não apenas por dano material, como acontece na maioria dos casos, mas também por dano moral caso constatado tal detrimento ao consumidor, para portanto, atuar como meio para garantia dos direitos e da manutenção de um ambiente favorável para o crescimento do e-commerce e proteção do consumidor.

Palavras-chave: dano moral; comércio; consumo virtual. 


\begin{abstract}
Against the evolution of computing and all its subsequent innovations, the consumer relations suffered changes, in the last few decades. In this regard, the virtual stores can also cause damages for the disadvantaged parties in the juristic act, that is, the consumer. Because of the great increasing in this kind of commerce, the complaints have been also increasing proportionally in the past few years. Therefore, the Law, that controls the society, must follow this tecnological evolution, as well as the population's consuming profile, in order to be ready for its changing needs in the legal scope. Thus, this paper aims to analyze the compensation for moral damages in case of e-commerce purchases, by researching through the jurisprudence, doctrines and the legislation (Civil Code and Consumer

Protection Code). For the virtual companies and stores, this juridical support to the consumer also enables a higher security in business, once it creates a palpable assurance. That said, this paper aims to emphasize the need of a norm related to the virtual environment and the compensation, not only for material damage, which has happened in most cases, but also for verified moral damage to the consumer, so that it can assure the rights and the keeping of an environment enabling the increasing of e-commerce and consumer's protection.
\end{abstract}

Keywords: Moral damage, Commerce, E-commerce.

\title{
1. O DESENVOLVIMENTO TECNOLÓGICO DO PAÍS COMO COMBUSTÍVEL PARA UMA NOVA PERSPECTIVA DE RELAÇÃO DE COMPRA E VENDA
}

É nítido que o surgimento dos computadores, dos celulares e da Internet atuam como "divisor de águas" na trajetória do desenvolvimento tecnológico da sociedade mundial, desempenhando um papel cada vez mais importante na vida da grande maioria dos brasileiros.

De início, a Constituição Federal, pilar de todas as normas vigentes no país, prevê a garantia do desenvolvimento econômico e social no território brasileiro, constituindo-se objetivos fundamentais da República Federativa do Brasil esse desenvolvimento nacional, conforme elucidado no art. $3^{\circ}$, II da própria Constituição Federal.

Em decorrência dessa busca desenfreada por desenvolvimento da nação, surgem a todo instante novas tecnologias de informação e comunicação, de forma que atualmente todos os indivíduos possuem contato direto ou indireto com as mesmas.

Historicamente, foi na Segunda Guerra Mundial que surgiram, de fato, os computadores na ideia que se conhece hoje. A Marinha dos Estados Unidos, em conjunto com a Universidade de Harvard, desenvolveu o computador Harvard Mark I, projetado por Howard Aiken, com base no calculador analítico de Babbage. O Mark I ocupava $120 \mathrm{~m}^{3}$ aproximadamente, e conseguia multiplicar dois números de dez dígitos em três segundos.

Em continuidade, com o surgimento do computador, mais tarde observou-se a necessidade de criar um sistema de comunicação entre as máquinas desenvolvidas. Tratando- 
se do surgimento da Internet no Brasil, o primeiro contato, de acordo com Eduardo Vieira (2003, p. 08-09) ocorreu em 1988, quando a Fundação de Amparo à Pesquisa do Estado de São Paulo juntamente com a Secretaria de Ciência e Tecnologia realizou a primeira conexão à rede através de uma parceria com o Fermilab, um Centro de Pesquisa de grande relevância dos Estados Unidos. Desse modo,

o governo federal aderiu também ao acesso à internet em 1992, com a criação da Rede Nacional de Pesquisa (RNP), pelo Ministério da Ciência e Tecnologia $(\mathrm{MCT})$ e, [...] paralelamente, surgiu no Rio de Janeiro uma organização nãogovernamental (ONG), chamada de Instituto Brasileiro de Análises Sociais e Econômicas (Ibase), que se tornaria a primeira instituição brasileira fora do ambiente acadêmico a utilizar a internet através do Alternet, que era nada mais do que um serviço de correio eletrônico e grupos de discussão conectados à rede, em 18 de julho de 1989 (VIEIRA, Eduardo, 2003, p. 08-09).

Nessa perspectiva, mais adiante, tendo o acesso à internet facilitado e se dissipando ao redor do mundo, no ano de 1995 surgem nos Estados Unidos alguns dos nomes mais importantes da Internet como produto, o site de busca "Yahoo!" e a livraria virtual “Amazon.com", sendo este mesmo ano considerado mundialmente, incluindo o Brasil, o marco histórico da Internet comercial (VIEIRA, Eduardo, 2003, p. 11), ou seja, a internet como instrumento para uma relação consumerista, possibilitando compra e venda de produtos e serviços nos mais diversificados ramos.

De maneira consoante, o doutrinador Samuel Huntington explana que "o maior desafio da evolução humana é cultural, e o mesmo se diz para o Direito, sendo assim, o Direito atua como um instrumento de regulamentação de condutas refletindo realidade da sociedade, ou seja, as normativas jurídicas devem se adequar a realidade social" (HUNTINGTON, Samuel, 1996).

Assim, o acesso à Internet foi se espalhando e adquirindo espaço em cada lar brasileiro de uma maneira extremamente rápida, se comparada a outros tipos de mudanças sociais, atingindo pessoas de todas as idades, classes sociais e etnias, gerando alterações no comportamento da sociedade em geral e, consequentemente, na cultura, sendo combustível para novas maneiras de relação consumerista.

Com essa inserção da internet toda a sociedade sofreu mudanças, possibilitando inovação nos meios de comunicação; novas maneiras de relação consumerista; alteração do modo de vida da população e, consequentemente, gera uma necessidade de evolução no Direito. Dessa maneira, diante de toda essa evolução da informática que trouxe inovações, as relações de consumo sofreram alteração de modo com que as empresas e lojas virtuais não podem ser excluídas de reparar possíveis danos que venham a lesar o consumidor, ainda que o negócio 
jurídico seja efetivado virtualmente, não ignorando a relação de consumo existente entre as partes.

Portanto, o Direito não pode esquivar-se das possíveis lides que vierem a surgir em decorrência de tal mudança, devendo estar preparado para solucionar de maneira justa a problemática.

\section{A NOVA MODALIDADE DE CONSUMO E O PERFIL DA SOCIEDADE CONSUMERISTA ATUAL}

Em consonância, o contexto de interação entre as pessoas e as informações tem influência na maneira como se relacionam, pensam e consomem produtos. De acordo com a pesquisa realizada pelo Net Effect Systems ${ }^{6}$ no ano de 1999, cerca de $80 \%$ dos usuários da época não utilizavam o comércio eletrônico, sendo que a falta de segurança foi a principal justificativa para esse resultado. Portanto, logo após o seu surgimento, o comércio virtual enfrentou barreiras em virtude do medo das pessoas em fazerem suas compras pela internet.

Em contrapartida, no ano de 2014, esse número de vendas efetuadas via comércio eletrônico, saltou correspondendo a $10 \%$ do total de faturamento do comércio por ano ${ }^{7}$ no país, ultrapassando US $\$ 300,00$ bilhões revolucionando o meio de compra e venda de produtos, e, dessa forma, criando um comércio virtual denominado de "e-commerce", firmando um novo tipo de relação consumerista, sendo notório o grande crescimento que este apresenta.

De modo evidente, a Internet "ganhou" a confiança das pessoas e se popularizou, gerando mudanças no perfil dos consumidores e o modo como compram, possibilitando e incentivando um aumento na realização de negócios jurídicos de compra e venda através da internet.

Assim, cabe ressaltar que o e-commerce é interessante e vantajoso para o fornecedor pelo custo de manutenção e investimento serem inferiores ao do comércio físico, por não ter um despesas altas com diversos funcionários, aluguel do espaço, contas de energia e água mais caras e não precisar necessariamente ter o estoque físico no momento que o consumidor compra o produto de fato, basta entregá-lo no prazo estipulado para o mesmo.

Já o consumidor vê vantagem nesse tipo de comércio pela facilidade em não precisar nem sair do conforto de sua casa para efetuar a compra e ter o produto em mãos recebido

\footnotetext{
${ }^{6}$ Empresa da área de tecnologia atuante nos EUA.

${ }^{7}$ Segundo dados colhidos do e-commerce Brasil
} 
também em casa após alguns dias apenas. Além do preço dos produtos serem, muitas vezes, mais baixos que os comprados em uma loja física, devido a essas lojas virtuais repassarem o custo menor para o produto final, ficando, portanto, mais barato.

Em continuidade, havendo a parte consumidora; a parte fornecedora e a vontade de ambas em celebrar o contrato, tem-se uma relação consumerista. Desse modo, o e-commerce também se configura como uma relação consumerista.

Visto isso, o presente trabalho destaca a atuação do judiciário em meio à relação consumerista virtual acerca da reparação do dano moral. Além de observar o entendimento das doutrinas e da Lei perante tal problemática, pois com essa dissipação acelerada e o surgimento desse novo modo de compra de produtos ou serviços é necessário também um desenvolvimento do Direito, a fim de regulamentar e solucionar de maneira justa os conflitos que inevitavelmente surgem com esta nova prática de comércio.

\section{AS RELAÇÕES DE CONSUMO E O DIREITO}

Observado a evolução da tecnologia, da internet e do comportamento da sociedade através do novo perfil de consumidor pontua-se a indispensável proteção ao consumidor no cumprimento dos contratos dos negócios jurídicos firmados virtualmente.

Nesse sentido, ao momento que se contrai uma obrigação de dar ou de fazer, no âmbito do Direito Civil, tem-se um encargo e uma responsabilidade que se espera o cumprimento. O contrato de obrigação estabelecido, pelas partes deve ser cumprido. Caso ocorra o seu descumprimento, há consequências para as partes envolvidas.

Desse modo, em conformidade com o Código Civil, o não cumprimento do contrato por alguma das partes estabelecidas gera dano, e esse dano causado ao lesado na relação jurídica deve ser reparado. Havendo, portanto, obrigação de reparar, independentemente de culpa, nos casos especificados em lei, ou quando a atividade normalmente desenvolvida pelo autor do dano implicar, por sua natureza, risco para os direitos de outrem.

A proteção ao consumidor é fato de grande relevância ao país, cujo além do Código de Defesa do Consumidor, o próprio Código Civil normatiza a temática, elucidando em seu artigo 927: “Aquele que, por ato ilícito (artigos 186 e 187), causar dano a outrem, fica obrigado a repará-lo", e no artigo 944 do mesmo: “A indenização mede-se pela extensão do dano". Com isso, para melhor entendimento, é relevante a distinção dos diferentes tipos de dano presentes no ordenamento jurídico, no presente trabalho, ressalta-se o dano moral. 
Assim, o dano, de maneira geral, seria o "mal ou ofensa que tenha uma pessoa causado a outrem, da qual possa resultar uma deterioração ou destruição à coisa dele ou um prejuízo a seu patrimônio" (SILVA, 1993, p. 3).

Dando prosseguimento, dano material seria mais um elemento dos pressupostos da responsabilidade civil, conforme estabelece Flávio Tartuce. Nesse viés, o doutrinador Clayton Reis conceitua o dano material como aqueles que atingem os bens e objetos de natureza corpórea ou material e, por consequência, são suscetíveis de imediata avaliação e reparação possuindo valor econômico no campo das relações negociais.

Como adendo, vale conceituar também o dano moral, no qual, de acordo com a doutrinadora Maria Helena Diniz é “a lesão de interesses não patrimoniais de pessoa física ou jurídica, provocada pelo ato lesivo" (DINIZ, 2003, p. 84) e de maneira complementar, Carlos Roberto Gonçalves assevera que:

\begin{abstract}
dano moral é o que atinge o ofendido como pessoa, não lesando seu patrimônio. É lesão de bem que integra os direitos da personalidade, como a honra, a dignidade, intimidade, a imagem, o bom nome, etc., como se infere dos art. $1^{\circ}$, III, e $5^{\circ}$, V e X, da Constituição Federal, e que acarreta ao lesado dor, sofrimento, tristeza, vexame e humilhação" (GONCALVES, 2009, p.359).
\end{abstract}

Em continuidade, a comprovação da existência de dano material é mais simples, visto que possui a materialidade do dano evidente compreendendo documentos, comprovantes de pagamento, e outros.

Por outro lado, o dano moral é intrínseco ao indivíduo lesado, sendo que dificilmente é certificado através de documentos palpáveis, sendo bastante enigmático em virtude da sua subjetividade. Contudo, a problemática não pode ser ignorada pelo julgador nos casos concretos, devendo ser reconhecido através do contexto dos fatos.

Desse modo, é valioso que seja garantido aos consumidores os princípios do Código de Defesa do Consumidor e Código Civil, a fim de haver a reparação por danos morais, se couber, avaliando os casos minuciosamente para que o consumidor lesado, parte hipossuficiente da relação de consumo, não seja prejudicado em nenhuma hipótese.

Nesse aspecto, de acordo com a $37^{\circ}$ edição da pesquisa Webshoppers, realizada no ano passado (2018), feita pela Ebit em parceria com a Elo, o faturamento do e-commerce, em 2017, foi de $\mathrm{R} \$ 47,7$ bilhões e houve crescimento de 12\% em relação a 2016.

Em decorrência desse crescimento acelerado, ocorre, muitas vezes, o não cumprimento do contrato por parte do fornecedor, surgindo, portanto, demandas para o judiciário sanar esses litígios oriundos dessa nova modalidade de relação consumerista. 
Assim, toda vez que se constata uma violação do direito de um indivíduo determinado na relação consumerista, percebe-se uma ofensa à esfera patrimonial do mesmo e dependendo do caso atinge também à esfera moral, devendo ser julgado pelo judiciário para conseguir a reparação na forma de indenização.

\section{O RECONHECIMENTO DO DANO MORAL NAS RELAÇÕES CONSUMERISTAS VIRTUAIS}

Com o "baixo custo" 8 em manter uma loja virtualmente, o mercado de comércio virtual tornou-se atrativo e cresceu significativamente nos últimos anos. Juntamente com isso, o assustador aumento do acesso das pessoas com acesso à internet contribuiu de maneira positiva, impulsionando ainda mais esse tipo de comércio.

Contudo, acompanhado do crescimento das vendas, vêm as situações em que o serviço não é satisfatório ao consumidor, necessitando assim, da busca pelo judiciário para sanar a lide gerada. E, é nesse aspecto que o papel do Direito se faz importante e deve acompanhar o avanço tecnológico da sociedade, progredindo para que as leis proporcionem segurança e amparo aos mesmos.

Destarte, observando o cenário jurídico atual e as jurisprudências a respeito do referido tema, a problemática se revela da dificuldade do judiciário em reconhecer o dano moral oriundo da compra por intermédio da internet, pois há uma falta de mecanismos normativos específicos para esse tipo de relação consumerista.

Em virtude de o dano moral ser intrínseco ao lesado, há uma grande dificuldade de comprovação na forma de documentos. Entretanto, não se pode fingir que ele não está presente e julgá-lo inexistente.

Como já mencionado no presente trabalho, o dano moral é a lesão causada a outrem o atingindo como pessoa, não seu patrimônio, o que torna injusto a ideia de não ser reconhecido perante as compras realizadas pela internet.

Nessa perspectiva, a título exemplificativo para tornar a problemática mais palpável, tem-se o caso hipotético em que um indivíduo realiza a compra de um brinquedo infantil destinado a presentear uma criança, sua sobrinha, na noite de Natal. O consumidor toma todos os devidos cuidados em realizar a compra com bastante antecedência para que produto esteja em mãos no tempo hábil de entrega-lo à criança na data dita por ele, visto que é algo que ela

\footnotetext{
${ }^{8}$ Baixo custo em relação aos gastos em manter uma loja física de mesmo porte.
} 
espera com ansiedade há meses, e, conforme as informações da loja, o prazo máximo estipulado para entrega está de acordo. Entretanto, ocorre que por negligência da loja fornecedora, o prazo limite de entrega se encerra, semanas depois o Natal chega e, o produto ainda não foi entregue ao consumidor.

O indivíduo sofre o dano material, visto que pagou pelo produto e não recebeu e, ainda, observa-se a lesão moral sofrida, pois ele se comprometeu a presentear a criança na data do Natal, prometendo que ela ganharia o produto tão esperado, mas isto não ocorreu por falha do fornecedor, gerando uma situação de desconforto, vergonha e frustração perante a criança.

O judiciário, em sua maioria, ainda tapa os olhos diante de situações como esta, pois ainda não acredita que as compras oriundas do comércio virtual podem gerar danos morais ao consumidor, encarando como mero aborrecimento e entendendo que o simples inadimplemento não gera o dever de indenização, o que vai à contramão dos princípios constados nas normas do Código de Defesa do Consumidor.

Essa dificuldade de reconhecimento do dano moral nas compras efetuadas por ecommerce aumenta ainda mais em virtude da falta de normatização. O Direito necessita adequar-se na medida em que a sociedade se modifica, a fim de conseguir sanar as problemáticas existentes no meio social do país, ressaltando que a parte hipossuficiente da relação jurídica tenha amparo jurídico também nesses casos.

Nada obstante, existem alguns poucos julgados que configuram e reconhecem o dano moral em compras e-commerce, como por exemplo, o entendimento do Egrégio Tribunal de Justiça do Estado de Minas Gerais dar-se-á:

APELAÇÃO CÍVEL - AÇÃO DE RESCISÃO CONTRATUAL C/C RESTITUIÇÃO DE QUANTIAS PAGAS E INDENIZAÇÃO POR DANOS MORAIS - COMPRA VIA INTERNET - MERCADORIA NÃO ENTREGUE - DANO MORAL - CONFIGURAÇÃO - VALOR DA INDENIZAÇÃO - RAZOABILIDADE E PROPORCIONALIDADE. Constatada a falha na prestação do serviço, consubstanciada na não entrega dos produtos adquiridos pelo consumidor na internet, a fornecedora deve responder pelos danos experimentados pelo autor. - $\mathrm{O}$ valor da indenização deve ser fixado segundo os princípios da razoabilidade e proporcionalidade, mostrando-se apto a reparar, adequadamente, o dano suportado pelo ofendido, servindo, ainda, como forma de obstar a reiteração da conduta ilícita pelo condenado. - Os honorários advocatícios de sucumbência devem ser fixados de acordo com os parâmetros traçados pelo art. 20 do CPC, não se mostrando razoável a redução pretendida pela parte autora. - A sentença que entendeu dessa forma deve ser mantida e o recurso não provido. Processo: Apelação Cível 1.0439.12.017249-9/001 0172499-77.2012.8.13.0439 (1); Relator(a): Des.(a) Mariângela Meyer; Data de Julgamento: 26/11/2013; Data da publicação da súmula: 06/12/2013). 
Em avença, o entendimento jurisprudencial do Egrégio Tribunal do Estado de São Paulo é elucidado:

EMENTA INDENIZAÇÃO POR DANO MORAL. COMPRA DE BICICLETA PELA AUTORA PARA PRESENTEAR SUA FILHA NO NATAL. NEGOCIAÇÃO FEITA PELA INTERNET. AUSÊNCIA DA ENTREGA DO PRODUTO DENTRO DO PRAZO. DANOS MORAIS. OCORRÊNCIA. INDENIZAÇÃO. REDUÇÃO DEVIDA. $\mathrm{O}$ transtorno causado à autora pelo não recebimento do produto que foi adquirido para presentear sua filha na noite de Natal aliado ao descaso da ré em tentar resolver o problema com certeza lhe causaram aborrecimentos indevidamente e transtornos que ultrapassaram o mero dissabor, ensejando a condenação por danos morais. Quantum indenizatório que deve ser fixado com base nos critérios da razoabilidade e da proporcionalidade, a fim de reparar o dano moral experimentado, sem caracterizar enriquecimento indevido. Recurso parcialmente provido.

TJ-SP- Apelação- APL 10003088920188260001. Data de publicação: 10/10/2018.

Assim, nos casos em tela, os julgadores observaram a lesão do consumidor também de natureza moral, reconhecendo que houve o dano moral e que o lesado deveria sofrer a devida reparação pelo fato lesivo ocorrido.

Por conseguinte, a reparação por dano moral nas compras realizadas pelo comércio eletrônico virtual deve ser analisada categoricamente de maneira individual, observando a possível lesão sofrida pelo consumidor, para que o mesmo não seja prejudicado de maneira alguma, sendo importante ressaltar o preceito da boa-fé em ambas as partes do negócio jurídico.

Por fim, o direito necessita adequar-se às necessidades do meio social em que se encontra. Dessa maneira, dependendo da finalidade do produto, comprovado os fatos da compra e falha da entrega ocorridos, os tribunais devem levar em consideração a indenização por dano moral, já que muitas vezes, todo o transtorno gerado pelo não cumprimento do contrato por parte do fornecedor causou constrangimento, estresse, tensão e afins, ocasionando dano psicológico ao consumidor, atingindo sua moralidade.

\section{REFERÊNCIAS}

BARBOSA, Simone Diniz Junqueira; SILVA, Bruno Santana da. Interação HumanoComputador. Elsevier Editora Ltda, Rio de Janeiro, 2010, p. 44. Disponível em: https://books.google.com.br/books?hl=pt-

BR\&lr=lang_pt\&id=qk0skwr_cewC\&oi=fnd \&pg=PP2\&dq=surgimento+do+computador $+\& o$ ts=RND15ImXft\&sig=cQNAiCAa_x11ijBL9HwsdISiW7s\#v=onepage \&q=surgimento $\% 20 \mathrm{do}$ $\% 20$ computador\&f=false Acesso em: 09 jul. 2019. 
CARVALHO, Marcelo Sávio Revoredo Menezes de. A Trajetória da Internet no Brasil: do surgimento das redes de computadores à instituição dos mecanismos de governança. 2006. Monografia (Mestrado) - Universidade Federal do Rio de Janeiro, Rio de Janeiro, 2006. Disponível em:

https://www.researchgate.net/profile/Marcelo_Carvalho17/publication/268809917_A_TRAJE TORIA_DA_INTERNET_NO_BRASIL_DO_SURGIMENTO_DAS_REDES_DE_COMPU TADORES_A_INSTITUICAO_DOS_MECANISMOS_DE_GOVERNANCA/links/54774a4 30cf2a961e4825bd4.pdf. Acesso em: 30 abr. 2019.

DINIZ, Maria Helena. Curso de Direito Civil Brasileiro - Responsabilidade Civil. 33 ed. São Paulo: Saraiva, 2019. v. VII.

FRANCO, Júlio César silva Mendonça. Danos Morais: compensabilidade e quantificação. 2008. Monografia (Mestrado em direito) - Universidade Estadual Paulista "Júlio de Mesquita Filho", Franca, 2008. Disponível em:

http://www.dominiopublico.gov.br/download/teste/arqs/cp069507.pdf. Acesso em: 1 maio 2019.

GONÇALVES, Carlos Roberto. Direito civil brasileiro. 16. ed. São Paulo: Saraiva, 2008. v. III.

KEAMPF, Karl. Historical Monograph: Electronic Computers Within the Ordnance Corps. Cap. 2, 1961, p. 19-39.

LORENZETTI, Ricardo L. Comércio eletrônico. São Paulo: Revista dos Tribunais, 2004.

LUNARDI, Guilherme. 12 dados que comprovam o crescimento do e-commerce no

Brasil. [S. 1.], 18 jun. 2018. Disponível em: https://www.ecommercebrasil.com.br/artigos/12dados-que-comprovam-o-crescimento-do-e-commerce-no-brasil/. Acesso em: 1 maio 2019.

MARQUES, Claudia Lima. Contratos no Código de Defesa do Consumidor: O novo regime das relações contratuais. 5. ed. São Paulo: Revista dos Tribunais, 2006.

MARQUES , Claudia Lima; BENJAMIN, Antônio Herman V.; MIRAGEM, Bruno. Comentários ao Código de Defesa do Consumidor. São Paulo: Revista dos Tribunais, 2006. Disponível em:

https://edisciplinas.usp.br/pluginfile.php/28422/mod_resource/content/1/Claudia\%20Lima\%2 0Marques\%20-\%20Comentários\%20art.\%2043\%20CDC.pdf. Acesso em: 1 maio 2019.

PLANALTO. Decreto-Lei no 7962, de 15 de março de 2013. . Brasília, 15 mar. 2013. Disponível em: http://www.planalto.gov.br/ccivil_03/_Ato20112014/2013/Decreto/D7962.htm. Acesso em: 1 maio 2019.

REIS, Clayton. Avaliação do dano moral. 3. ed. Rio de Janeiro: Forense, 2000, p. 8-9

SARAIVA, Vade Mecum. Constituição Federal. São Paulo, ed. Saraiva, 2018.

SILVA, De Plácido e. Vocabulário Jurídico,12. ed., Rio de Janeiro: Forense, 1993, v. I. p. 3.

SOBHIE, Amir Ayoub; DE OLIVEIRA, Deymes Cachoeira. Proteção do Consumidor no Comércio Eletrônico: Inovações relevantes para as vendas on-line no Brasil a partir do Decreto Federal $n^{0}$ 7.962/2013. Revista Eletrônica de Iniciação Científica, Itajaí, p. 84107, 30 out. 2013. Disponível em: https://www.univali.br/graduacao/direito- 
itajai/publicacoes/revista-de-iniciacao-cientifica-

ricc/edicoes/Lists/Artigos/Attachments/934/Arquivo\%2006.pdf. Acesso em: 30 abr. 2019.

SUPERIOR TRIBUNAL DE JUSTIÇA DO ESTADO DE MINAS GERAIS. Apelação Cível 1.0439.12.017249-9/001 0172499-77.2012.8.13.0439 (1); Relator(a): Des.(a) Mariângela Meyer; Data de Julgamento: 26/11/2013; Data da publicação da súmula: 06/12/2013).

TARTUCE, Flávio. Direito civil: direito das obrigações e responsabilidade civil. 8. ed. Rio de Janeiro: Forense, 2014, p. 344, v. 2.

VIEIRA, Eduardo. Os Bastidores da Internet no Brasil: A história de sucesso e de

fracasso que marcaram a web brasileira. Barueri- SP: Editora Manole Ltda, 2003, p. 8-11.

Disponível em: https://books.google.com.br/books?hl=pt-

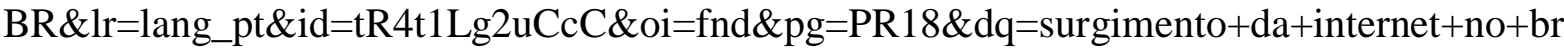
asil\&ots=0iXUVNJqA9\&sig=09QmaoL3-

vHTBh0AAi07wyKkXsk\#v=onepage \&q=surgimento\%20da\%20internet $\% 20$ no $\% 20 \mathrm{brasil} \& \mathrm{f}=$ false Acesso em: 09 jul. 2019. 


\section{A IMPORTÂNCIA DA LOGÍSTICA REVERSA NO MANEJO DE RESÍDUOS SÓLIDOS: OS BENEFÍ́CIOS AO CICLO PRODUTIVO}

The importance of reverse logistics in solid waste management: the benefits to the production

$$
\text { cycle }
$$

\section{Eduarda Possebom Elias}

Graduação em Direito em andamento pela Universidade do Estado de Minas Gerais -UEMG/Frutal; Atuou como estagiária de Direito em órgão público e privado. Atualmente, atua como estagiária na Delegacia de Polícia Civil da cidade de Frutal/MG; Foi bolsista de Iniciação Científica do Programa Institucional de Apoio à Pesquisa - PAPq/UEMG; Experiência em pesquisa e publicação no âmbito dos Direitos Humanos, Direito Penal, Direito Processual Penal e Direito Processual Civil. E-mail: eduarda.possebom@hotmail.com

\section{Maria Clara da Guarda Queiroz.}

Graduação em Direito em andamento pela Universidade do Estado de Minas Gerais-UEMG/Frutal; Formada em Técnico em Informática para Internet pelo Instituto Federal do Norte de Minas Gerais - Campus Januária. Atua como estagiária em escritório de advocacia especializado em Direito Previdenciário. E-mail: mclara.g.queiroz@gmail.com

\section{Cristina Veloso Castro}

Professora do Programa de Pós-Graduação Stricto Sensu em Ciências Ambientais da Universidade Brasil - Campus de Fernandópolis. Professora de Direito Constitucional na Universidade do Estado de Minas Gerais - UEMG. Possui pós doutorado em Direito e Saúde, pela Universidade de Messina, Itália, doutorado em Sistema Constitucional de Garantias de Direito pelo Instituto Toledo de Ensino, graduação em Direito - Faculdades Integradas Rio-pretense, mestrado em Direito pela Universidade de Ribeirão Preto e doutorado em Derecho Empresarial pela Universidade de Extremadura. E-mail: cristina.castro@uemg.br

Resumo: O presente artigo tem o intuito de explicitar o crescente debate sobre a importância da logística reversa no mundo consumerista, a qual se introduz como uma estratégia organizacional de relevante importância quanto ao ganho empresarial no tocante à redução de custos através da reciclagem de materiais descartados. Além do benefício próprio das grandes empresas, encontramos no arcabouço geral da temática, o benefício ao meio ambiente ao nos debruçarmos para a compreensão da significância da logística reversa quanto à conscientização e sustentabilidade. O impulso para tal pesquisa foram as novas modificações na legislação quanto ao que se debate sobre os resíduos sólidos e sua efetividade quanto à conscientização do desenvolvimento sustentável do mercado. Isto posto, o artigo tem o intuito de trazer o reconhecimento e um debate construtivo sobre tal método, que vem, de forma promissora, se efetivando em nosso país. Outrossim, debaterá também, sobre as problemáticas enfrentadas e a apresentação da Política Nacional de Resíduos Sólidos (PNRS), pautado perante a lei, na qual traz a mitigação das contrariedades encontradas para a aplicação da logística reversa em nosso país. Portanto, a determinação é clarear e elucidar os seus benefícios através de um gerenciamento correto de produção. Por fim, para a elucidação da logística reversa vista na prática, o texto científico traz em seu corpo demonstrações de ações realizadas por grandes empresas que usam de tal método para seu benefício, assim como para o benefício do meio ambiente, que, de forma positiva, reverberam para um meio consumerista mais sustentável.

Palavras-chave: Logística reversa, sustentabilidade, Política Nacional de Resíduos Sólidos. 


\begin{abstract}
This paper aims to explain the increasing debate regarding the importance of reverse logistics in the consumerist world, which can be understood as a relevant organizational strategy in business benefits, in terms of cost-cutting by recycling of disposed supplies. In addition to the benefit for large companies, we find in this general matter, benefits to the environment, by understanding the significance of reverse logistics in terms of awareness and sustainability. The impetus for this research were the new modifications in the law regarding the solid waste and its debate's efficacy concerning the awareness about sustainable market development. That said, this paper aims to bring recognition and a constructive debate about this method, which has been promising in our country. In addition, it will bring explanations regarding the problems faced and the presentation of the National Solid Waste Policy (PNRS), based on the law, which brings the mitigation of the difficulties encountered in the application of reverse logistics in our country. Therefore, the point is to clarify and elucidate its benefits through proper production management. Finally, in order to elucidate the reverse logistics seen in practice, the scientific text brings examples of ecisions taken by large companies that use this method for their benefit, as well as for the benefit of the environment, which, in a positive way, reverberate for a more sustainable consumer environment.
\end{abstract}

Keywords: Reverse Logistics, Sustainability, National Solid Waste Policy.

\title{
INTRODUÇÃO
}

O impacto ambiental sofrido ao longo do tempo pelas grandes massas de mercado para o suprimento do consumo exacerbado de nossa sociedade contemporânea vem sendo, nas últimas décadas, um alerta para que ocorra o desenvolvimento organizacional, preocupando-se com o impacto de seus meios de produção.

Há de se salientar que, por muitos anos, o meio ambiente foi deixado em segundo plano, ao passo que o desenvolvimento e a alta produção fazia frente à relevante magnitude do mercado consumerista. Com o visível esgotamento de recursos naturais, foi necessário entender que para dar prosseguimento ao crescimento das organizações, teriam de implementar práticas para seu próprio benefício assim como de terceiros, repercutindo na preservação do meio ambiente e, consequentemente, destes recursos naturais. Nesta linha de raciocínio, fica evidente a importância de termos a sustentabilidade como aliada da linha de produção, esta na qual se baseia no conjunto de remanejo ou estratégia que visa garantir a sobrevivência destes recursos, obtendo um tripé cadenciado vantajoso, sendo estes, a indústria, o meio social e o meio ambiente.

Para o discorrimento do tema, faz-se necessário explanar sobre tal tendência estratégica que vem progredindo de maneira positiva no território brasileiro, sendo esta a logística reversa, a qual consiste em um instrumento para a aplicação responsável do ciclo de 
vida dos produtos, viabilizando a coleta e o retorno dos resíduos sólidos ao mercado de produção, para o seu reaproveitamento ou em uma destinação adequada para a menor degradação possível ao meio ambiente.

No transcorrer destes últimos anos, foi observado um gradativo e significante interesse de empresas atuantes do território brasileiro na busca de integrar suas atividades no campo da logística reversa, analisando novas tecnologias de reaproveitamento de produtos, versando em atividades típicas da logística e introduzindo a prática em seu meio de produção. A logística reversa, portanto, está conectada em uma série de questões significativas para que haja o desenvolvimento consciente no mercado, sendo imprescindível o estudo quanto à sua gestão para uma sociedade sustentável.

Com foco nas políticas públicas relacionadas ao meio ambiente, em especial a logística reversa, o presente resumo tem por objetivo compreender a funcionalidade desta prática, o qual progressivamente vem ganhando espaço por seus princípios de sustentabilidade ao gerar uma produção de baixo impacto. Neste diapasão, trará de maneira pormenorizada para o conteúdo a importância e benefícios do uso da logística reversa no mercado e alguns aspectos sob o enfoque econômico, ecológico, bem como sua aplicação conforme preceitua a Lei 12.305, de 2 de agosto de 2010.

Para deslindá-lo, como base metodológica adota-se a pesquisa bibliográfica, discutindo questões relativas ao assunto proposto, bem como a leitura analítica de trabalhos existentes no Direito Ambiental, visando para o entendimento do processo logístico para o respeito ao meio ambiente e os benefícios que favorecem o mercado.

\section{LOGÍSTICA REVERSA}

Ao conceituarmos a logística reversa, há de nos atentarmos às variadas interpretações que a doutrina nos traz. Por ser um método em constante evolução pelo crescente interesse de grandes empresas, é de sua natureza ter conceituações esparsas de sua função no meio de produção. Para tanto, Lacerda traz com maestria o conceito de logística reversa.

Logística reversa pode ser entendida como sendo o processo de planejamento, implementação e controle do fluxo de matérias-primas, estoque em processo e produtos acabados (e seu fluxo de informação) do ponto de consumo até o ponto de origem, com o objetivo de recapturar valor ou realizar um descarte adequado. (Lacerda, 2002)

Sua denominação é dada, em síntese, pois não segue o fluxo normal da logística de mercado, uma vez que ela se preocupa com o retorno de seu produto ao ciclo produtivo, agregando valores de diversos gêneros, sendo estes de natureza ecológica, econômica, de 
imagem corporativa, entre outros, conforme explicitado por Paulo Roberto Leite, em seu livro Sustentabilidade e Competitividade.

\section{A LOGÍSTICA REVERSA COMO ALIADA DO MERCADO E DA SOCIEDADE.}

De maneira perfunctória, o método compreende vários benefícios. Sob o aspecto econômico, nos deparamos com o ganho financeiro que as grandes empresas têm a partir da redução dos custos em matéria prima ao reutilizarem materiais descartados, trazendo novamente para a linha de produção todo objeto que, para os clientes finais, se tornaram irrelevantes e sem importância. Neste sentido, para o comprador, aquele produto que já não tem mais utilização e valor, para o mercado este material gera economia na produção.

No que diz respeito à sustentabilidade que a logística reversa pode nos proporcionar, nos deparamos com a diminuição da poluição, adotando a reciclagem como saída para a desenfreada quantidade de lixo que disseminamos e, até mesmo, o correto descarte desses materiais que não suprem os requisitos para retornarem a leva da produção. Por esta óptica, Lacerda aduz:

Os produtos podem ser revendidos se ainda estiverem em condições adequadas de comercialização, recondicionadas desde que haja justificativa econômica e recicladas se não houver possibilidade de recuperação gerando materiais que retornam ao sistema produtivo, ou em ultimo caso, descarte. (2009, p. 2)

\section{EMBATES ENFRENTADOS PARA EFETIVAÇÃO DO MÉTODO}

Como aludido anteriormente, nos dias atuais, as grandes empresas já compreenderam a importância da preservação do meio ambiente através do ciclo de vida de seus produtos, ao passo que fica claro o retorno econômico significativo, uma vez que viabiliza a coleta e restituição dos resíduos sólidos ao mercado de produção, reunindo, assim, a sustentabilidade que traz a benesse do menor impacto possível ao meio ambiente e a reutilização destes materiais por um baixo custo de produção. No que diz respeito à função indispensável da logística reversa para o retorno destes materiais, Lacerda (2002, apud GARCIA, 2006, p.4) acrescenta:

Logística reversa pode ser entendida como um processo complementar à logística tradicional, pois enquanto a última tem o papel de levar produtos de sua origem dos fornecedores até os clientes intermediários ou finais, a logística reversa deve completar o ciclo, trazendo de volta os produtos já utilizados dos diferentes pontos de consumo a sua origem. No processo da logística reversa, os produtos passam por uma etapa de reciclagem e voltam novamente à cadeia até ser finalmente descartado, percorrendo o "ciclo de vida do produto". 
Deste modo, atualmente, a logística reversa é de fundamental importância dentro da organização como um diferencial competitivo, sendo que esta controla os canais de distribuição da organização, além da armazenagem de produtos de forma dinâmica. Nesta óptica, uma logística empresarial bem empregada é capaz de reduzir os custos com transporte, distribuição e armazenagem de produtos, tornando a empresa ou organização mais competitiva no mercado por ter custos aquém do que empresas que não utilizam da mesma técnica. Segundo Ballou:

\begin{abstract}
A logística empresarial estuda como a administração pode prover melhora no nível de rentabilidade nos serviços de distribuição aos clientes e consumidores, através de planejamento, organização e controle para as atividades de movimentação e armazenagem que visam facilitar o fluxo de produtos. (1993, p.17).
\end{abstract}

Entretanto, como é observado, salienta-se que as ações presentes na logística reversa abrangem diversas etapas específicas para sua funcionalidade, podendo ser exemplificada de maneira perfunctória a coleta, inspeção, separação, compra e venda, devolução, visando uma recuperação sustentável. As técnicas utilizadas para que haja o ciclo da matéria, devolvendo-a para o plano empresarial, muitas vezes utiliza-se de grande custo para sua implantação, mesmo que em um futuro propínquo haja o retorno satisfatório de seu planejamento sustentável, e, além do mais, a falta de informação dos empresários brasileiros frente ao assunto discorrido corrobora para a dificuldade de se implementar a técnica da logística reversa no setor industrial de forma difundida.

Visto isso, é necessário medidas que estimulem o mercado para o conhecimento e interesse desta prática, desde pequenas a grandes empresas, utilizando-a de forma a garantir a efetivação de seus próprios benefícios e em prol do benefício alheio.

\title{
4. A MitigaÇÃo dAS PROBLEMÁticas ENFRENTAdAS NA LOGÍSTICA REVERSA POR POLÍTICAS PÚBLICAS E SUA CONCRETIZAÇÃO OBRIGATÓRIA PERANTE A LEI 12.305/2010.
}

Para a satisfação do método da logística reversa, há de se compreender para as bases que devem ser feitas para concretizá-la. Como visto anteriormente, há um valor para sua realização, assim, com o implemento de políticas públicas que impulsionem este recurso e uma Lei rígida que a faça ser cumprida, sua concretização se torna alcançável.

No ano de 2010, foi decretada a Política Nacional de Resíduos Sólidos (PNRS) lei que tem como princípio a responsabilidade compartilhada entre governo, empresas e população. Ela tem o princípio de impulsionar a volta de produtos usados novamente às indústrias, tratando os resíduos de forma responsável, assim, desenvolvendo a ideia fundamentada da logística reversa, 
bem como trazendo um projeto de inclusão social perante a reciclagem feita pela população, cabendo, assim, ao poder público de educar estes para a coleta seletiva destes produtos descartados.

No campo industrial, a lei supracitada determina que os fabricantes, importadores, distribuidores e comerciantes façam o recolhimento dos produtos e dos resíduos remanescentes após o uso, bem como sua destinação final.

Deste modo, nota-se que o PNRS oportuniza o avanço das ações de logística reversa, ao passo que os produtos são recolhidos após o uso o consumo pela população para o retorno como matéria prima à produção industrial. Os fabricantes de produtos tiveram que repensar a cadeia e as embalagens para que se tornem cada vez mais eficientes e rápidas para seu retorno dentro do ciclo de consumo. Em contrapartida, dá ao consumidor obrigações e penalidade, em caso de descobrimento que afetem a destinação correta de resíduos.

Essas atividades propiciam os benefícios econômicos, a economia de recursos naturais, além de menor emissão de gases. É indubitável a quantidade de benesses que a prática da logística reversa entrega ao mercado que a exerce.

\section{A IMPLEMENTAÇÃO DA LOGISTICA REVERSA NO BRASIL: ESTRÁTEGIAS QUE VIABILIZAM A APLICAÇÃO DA POLÍTICA NACIONAL DE RESÍDUOS SÓLIDOS}

A entrada em vigência da Lei de Resíduos Sólidos (12.305/2010), propulsionou a iniciativa de empresas em implementar medidas que preveem a redução na geração de resíduos, aumentando os níveis de reciclagem e reutilização dos insumos gerados por suas produções. A responsabilidade dada a essas companhias de montar uma estratégia que destina de forma ambientalmente adequada os rejeitos e resíduos produzidos por elas, é compartilhada entre o poder público, fabricantes, importadores, distribuidores e comerciantes, dando obrigatoriedade a ambos de garantir a efetivação dos mecanismos sustentáveis que foram desenvolvidos, como determina a lei ali citada.

No Brasil, há empresas que se destacam no gerenciamento de métodos que dão "fins" sustentáveis aos resíduos sólidos, gerando tanto impactos ambientais positivos, quanto econômicos.

\subsection{Natura Cosméticos}


Pioneira na utilização de refis de embalagens de alguns de seus produtos (ação que contribui para a retirada de 1,6 mil toneladas de plástico, por ano, do meio ambiente, segundo dados da empresa), a Natura Cosméticos se destaca por seus meios sustentáveis de produção.

Através dos programas "Elos" e "Dê a Mão para o Futuro", a empresa atende ao que determina a Política Nacional de Resíduos Sólidos, utilizando da logística reversa, com a iniciativa de reciclar e adicionar matéria reciclada à produção de embalagens utilizadas no armazenamento de seus produtos. O programa "Elos", é focado na incorporação de materiais reciclados, pós-consumo, nessas embalagens, sendo responsabilidade compartilhada entre a empresa e seus fornecedores em conhecer todo o percurso dessa matéria-prima, desde sua origem até o produto final. Os frascos utilizados na linha de óleos corporais "Sève", passaram a ser feitos desde 2018, com plástico 100\% reciclado pós-consumo.

A Natura aderiu ao projeto "Dê a Mão para o Futuro", programa de inciativa da Associação Brasileira da Indústria de Higiene Pessoal, Perfumaria e Cosméticos (ABIHPEC), e é por meio dele, que a empresa promove estímulos à conscientização da população em relação a coleta seletiva, além de fomentar o trabalho realizado em cooperativas de reciclagem, aumentando sua eficiência, visando o crescimento na utilização de matéria-prima reciclável no país.

Ademais, a empresa estabeleceu metas a serem cumpridas até 2050, com diretrizes estratégicas na construção de impactos positivos. Dentre elas, a utilização de, no mínimo, 74\% de material reciclável na fabricação das embalagens de seus produtos e de $10 \%$ de matériaprima reciclada pós-consumo na massa total de todos os frascos e caixas usados em seus cosméticos. (NATURA, 2019).

\subsection{McDonald's Brasil}

A multinacional especialista em restaurantes fast-foods, iniciou em 2010, em seus estabelecimentos brasileiros, a criação de um sistema que transforma o óleo de cozinha utilizado na preparação de alimentos, em biocombustível que abastece os caminhões de entrega da rede. Essa ação reduz em 26\% das emissões de gás carbônico pelos caminhões que abastecem seus restaurantes, além de gerar economia de $40 \%$ com a redução na compra de combustível pela companhia, como afirma o diretor-geral da Martin-Brower (empresa responsável pela logística e distribuição da rede de fast-foods), Tupã Gomes, em artigo publicado pela revista Globo Rural.

O procedimento utilizado pela empresa, consiste no recolhimento do óleo usado pelos mesmo caminhões que realizam as entregas de alimentos nas lojas da cadeia de restaurantes, 
logo após, sendo armazenado e transportado até uma usina de Biodiesel, formando assim, um ciclo no processo de logística reversa.

\subsection{Hewlett-Packard Company (HP)}

A companhia de tecnologia da informação, conhecida popularmente pela sigla HP, desenvolveu no país, o programa "HP Planet Partners Brasil”, que objetiva reciclar $100 \%$ dos cartuchos e toners vazios usados nas impressoras fabricadas pela empresa.

O processo de reciclagem se inicia na coleta seletiva feita pela empresa, através dos seus pontos de coleta, que podem ser localizados através do site da companhia. Depois, separados os componentes dos cartuchos e toners, as peças plásticas retiradas são trituradas e encaminhadas para o Canadá, para a fabricação de cartuchos e toners novos. Mais de $80 \%$ dos cartuchos de tinta e 100\% dos cartuchos de toner da HP LaserJet são fabricados com conteúdo reciclado.

A HP tem uma meta de reciclar 1,2 milhões de toneladas de hardware e suprimentos até 2025.

\subsection{Bridgestone Bandag}

Especializada na fabricação de pneus, a Bridgestone se preocupa com o descarte consciente de pneus usados e, por isso, mantém mecanismos de proteção ambiental, como a coleta seletiva. Os pneus recolhidos pela empresa, são encaminhados para a RECICLANIP, uma instituição criada pela Associação Nacional da Indústria de Pneumáticos (ANIP), da qual a Bridgestone é associada. Os pneus recolhidos são conduzidos a empresas especializadas em trituração e picotagem e esses fragmentos são matéria-prima reutilizada na fabricação de solas de sapato, borrachas para vedação e até combustível alternativo nas indústrias de cimento.

Referência mundial em logística reversa, a RECICLANIP, é protagonista na gestão de reciclagem de pneus usados no Brasil. A inciativa conta, além da Bridgestone, com outras industrias pneumáticas, como a Goodyear, Michelin, Pirelli e a Continental. A resolução nº 416 do Conselho Nacional do Meio Ambiente (CONAMA), publicada em 2009, antes da Lei de Resíduos Sólidos, estabeleceu obrigações a essas industrias, na intenção de prevenir a degradação do meio ambiente, causada por pneus inservíveis. Segundo dados do Instituto Brasileiro do Meio Ambiente e dos Recursos Naturais Renováveis (IBAMA), as empresas e fabricantes de pneus, alcançaram em 2017, 99,95\% da meta de destinação correta de pneumáticos, estando desde 2012, alcançando níveis acima de 90\%. Estes dados são coletados anualmente por esse órgão e publicados em relatórios. 


\section{Gráfico 1 - Percentual de cumprimento da meta de destinação nacional (2009-2017)}

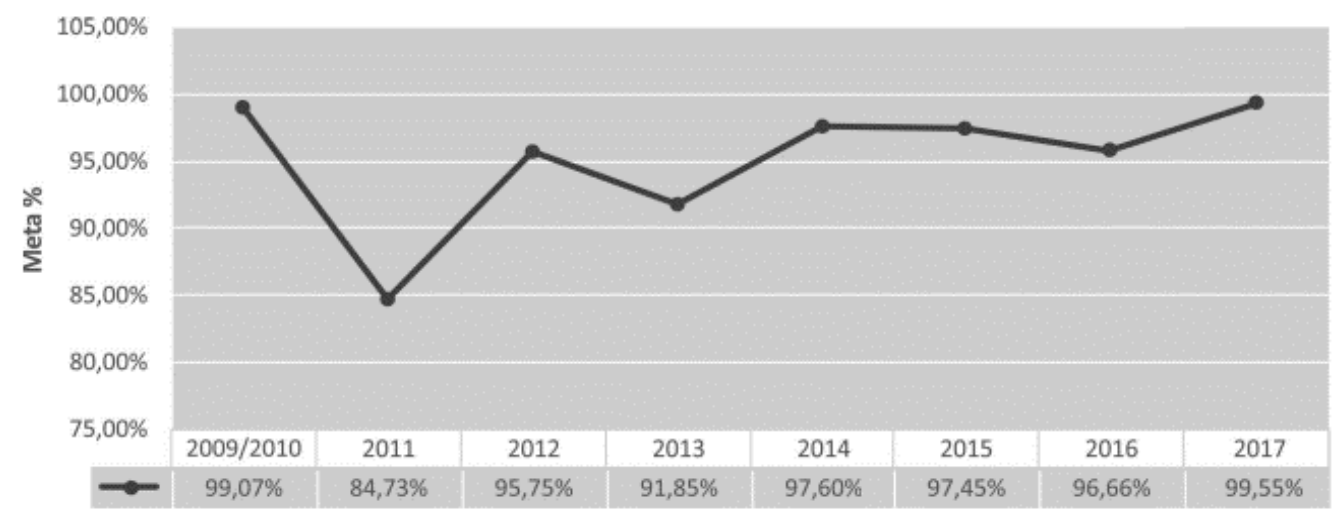

Fonte: CTF/Ibama

\section{CONCLUSÃO}

De acordo com o Ministério do Meio Ambiente, a produção diária de lixo nas cidades brasileiras chega a 150 mil toneladas. Deste total, 59\% vão para lixões e apenas $13 \%$ são reaproveitados. Neste sentido, fica fácil compreender a dificuldade que o Brasil ainda tem para colocar em prática a utilização da logística reversa.

Conclui-se então, a necessidade de conscientizar as empresas existentes para a implantação da logística reversa, obtendo para estas benefícios econômicos, por meio do emprego de um material reutilizado e através da credibilidade de mercado que a empresa recebe por parte de seus consumidores. A organização oferece também benefícios sociais, ao passo que se preocupa com o meio ambiente e com as gerações futuras, além de minimizar as consequências ambientais desastrosas dadas em função do descarte incorreto de lixo.

Ademais, fica explícito a inevitabilidade de uma troca simbiótica vantajosa para ambas as esferas, sendo estes o mercado, fazendo seu papel de maneira a minimizar ao máximo seu impacto diante ao meio ambiente com a aposta em planejamentos ligados à logística reversa, e o consumidor, com seu papel de fazer retornar de forma prática o produto não mais utilizado, entregando-o de volta para o ciclo sustentável de consumo.

\section{REFERÊNCIAS}

BRASIL. Lei ${ }^{\circ}$ 12.305, de 2 de agosto de 2010. Institui a Política Nacional de Resíduos Sólidos; altera a Lei no 9.605, de 12 de fevereiro de 1998; e dá outras providências. 
Disponível em <http://www.planalto.gov.br/ccivil_03/_ato2007-2010/2010/lei/112305.htm> Acesso em: 07 mai. 2019.

CAETANO, Mariana. McDonald's lança projeto de biodiesel a partir do óleo de cozinha. Disponível em:

<http://revistagloborural.globo.com/GloboRural/0,6993,EEC1711075-1934,00.html>. Acesso em: 20 set. 2019.

EESC JR. 5 Empresas que são Exemplos de Logística Reversa. Disponível em: <https://eescjr.com.br/blog/5-empresas-exemplos-de-logistica-reversa/> Acesso em: 20 set. 2019

GUARNIERI, Patrícia. Logística Reversa e os Impactos da PNRS. Portal Direito Ambiental. Disponível em: <http://direitoambiental.jimdo.com/ambienteemrevista/publicações-científicas/>. Acesso em: 07 mai. 2019.

HP. HP Planet Partners: Programa de Logística Reversa e Reciclagem. Disponível em: $<$ https://www8.hp.com/br/pt/hp-information/environment/product-recycling.html >. Acesso em: 21 set. 2019.

IBAMA. Relatório de Pneumáticos: Resolução Conama no 416/09. Disponível em: $<$ http://ibama.gov.br/phocadownload/pneus/relatoriopneumaticos/ibama-relatoriopneumaticos-2018_atualizado_em_novembro_2018.pdf> Acesso em: 20 set. 2019

ISTOÉ DINHEIRO. As 50 Empresas do Bem. Disponível em:

<https://www.istoedinheiro.com.br/noticias/negocios/20110401/empresas-bem/52137>. Acesso em: 21 set. 2019.

LACERDA, Leonardo. Logística reversa: Uma visão sobre os conceitos básicos e as práticas operacionais. Centro de Estudos em Logística-COPPEAD, p. 3, 2002.

LEITE, Paulo Roberto. Logística Reversa: Sustentabilidade e Competitividade. Editora Saraiva, São Paulo, 2017, $3^{\circ}$ Ed.

\section{MINISTÉRIO DO MEIO AMBIENTE. RESOLUÇÃO Nº 416, DE 30 DE SETEMBRO} DE 2009. Disponível em

<https://servicos.ibama.gov.br/ctf/manual/html/res_con_416_09.pdf> Acesso em: 21 set. 2019

\section{MOTONLINE. Bridgestone Realiza Logística Reversa Para Descarte de Pneus}

Disponível em <https://www.motonline.com.br/noticia/bridgestone-realiza-logistica-reversapara-descarte-de-pneus/> Acesso em: 19 set. 2019

NATURA. Menos plástico: Natura assina compromisso global para diminuir uso. Disponível em: <https://www.natura.com.br/blog/sustentabilidade/menos-plastico-naturaassina-compromisso-global-para-diminuir-uso >. Acesso em: 21 set. 2019

NATURA. Pense impacto positivo: visão de sustentabilidade 2050. Disponível em: $<$ https://static.rede.natura.net/html/home/2019/janeiro/home/visao-sustentabilidade-natura2050-progresso-2014.pdf>. Acesso em: 20 set. 2019. 
REVISTA HOUSEHOLD E COSMÉTICOS. Logística reversa é meta 'audaciosa' da Natura. Disponível em: <https://www.revistahec.com.br/materias/household/6044/19-022019/logistica-reversa-e-meta-\%E2\%80\%98audaciosa\%E2\%80\%99-da-natura>. Acesso em: 21 set. 2019.

WILLE, Mariana Muller. Logística Reversa: Conceitos, Legislação E Sistema De Custeio Aplicável. Disponível em <http://www.opet.com.br/faculdade/revista-ccadm/pdf/n8/LOGISTICA-REVERSA.pdf> Acesso em: 08 mai. 2019 


\title{
A MEDIDA PROVISÓRIA DA LIBERDADE ECONÔMICA (MP 881/2019) CONVERTIDA NA LEI No 13.874/2019 E A ALTERAÇÃO DO ART. 1052 DO CÓDIGO CIVIL
}

\author{
The Provisional Measure of economic freedom (PM 881/2019) converted into law $n$. \\ $13.874 / 2019$ and the modification of Civil Code's art.1052
}

Loyana Christian de Lima Tomaz

Doutoranda em Biocombustíveis pela Universidade Federal de Uberlândia. Mestrado em Filosofia pela Universidade Federal de Uberlândia. Graduação em Direito pela Faculdade Pitágoras de Uberlândia, graduação em Pedagogia pela Faculdade de Tecnologia Ciências e Educação. Professora adjunta da Universidade do Estado de Minas Gerais Frutal-MG, professora da Universidade Presidente Antônio Carlos- Uberlândia-MG. Ex-coordenadora do Curso de Direito da Universidade do Estado de Minas Gerais Frutal-MG. Tem experiência na área de Direito, com ênfase em Direito, atuando principalmente nos seguintes temas: Direito Civil e Direito Processual Civil, Filosofia do Direito, Intolerância Religiosa. Email: loyana.tomaz@uemg.br

\section{Rozaine Aparecida Fontes Tomaz}

Doutoranda pela Universidade Federal de Uberlândia- UFU, projeto interdisciplinar, programa em Biocombustíveis (inicio 1/2019). Possui mestrado em Educação pela Universidade de Brasília - UnB (área de concentração: Educação e Comunicação; Linha de Pesquisa: Educação, Arte e Linguagem), Mestrado em Toxicodependência e Patologias Psicossociais pelo Instituto Superior Miguel Torga Coimbra/PT. Especialista em Direito da Comunicação pela Faculdade de Direito da Universidade de Coimbra/PT; Especialista em Psicopedagogia; Psicanálise Clínica; Educação Especial: ênfase inclusão; entre outras. Graduada em Pedagogia; Filosofia; Estudos Sociais e Artes (Educação Artística) e Graduanda em Psicologia. Possui experiência em docência e coordenação de cursos no ensino básico e superior, atendimentos psicopedagógicos e implementação de projetos sociais, tanto na esfera privada quanto na esfera pública (Poderes Executivo e Judiciário). Docente na Universidade do Estado de Minas Gerais-UEMG/Frutal, nos cursos de Direito, Administração, Sistemas de Informação e Geografia (disciplinas: Filosofia do Direito, Filosofia e Ética Empresarial, Ética Profissional e Planejamento Educacional ); professora convidada de cursos de pós-graduação. Participa dos seguintes grupos de pesquisa CNPq: "Observatório de Violência e Práticas Exemplares" - USP/Ribeirão Preto; Centro Brasileiro de Estudos em Direito e Religião"UFU/CEDIRE/Uberlândia; Núcleo de Estudos em Gestão e Impactos Ambientais - NEGIA; sendo líder do grupo "Direito e (In)Tolerância Religiosa"- UEMG/Frutal. Coordenadora de projetos de extensão e de iniciação científica aprovados por agências de fomento como FAPEMIG, PAPq, PAEx/UEMG. E-mail: rozaine.tomaz@uemg.br

\section{Tainá Fagundes Lente}

Pesquisadora bolsista em Iniciação Científica do Programa Institucional de Apoio à PesquisaPAPq/UEMG. Pesquisadora vinculada aos grupos ABDCONST - Igualdade, Reconhecimento e Inclusão Social: Minorias e Grupos Vulneráveis - IRIS; e CNPq: Direito e (In)Tolerância Religiosa. Graduação em Direito em andamento pela Universidade do Estado de Minas Gerais- UEMG/Frutal. Já atuou como estagiária na $3^{\text {a }}$ Promotoria de Justiça da Comarca de Frutal - MG e no Núcleo de Prática Jurídica da UEMG/Frutal. Interessa-se por temas que versam sobre Direito Civil, com experiência em pesquisa e publicação. E-mail: taina.lente.fagundes@gmail.com

Resumo: O presente artigo objetiva discorrer sobre a alteração do art. 1052 do Código Civil, por meio da Medida Provisória da Liberdade Econômica (MP 881/2019), convertida na Lei $\mathrm{n}^{\circ}$ 13.874/2019. A lei acrescenta os parágrafos $1^{\circ}$ e $2^{\circ}$, prevendo a criação da sociedade unipessoal. Nesse intuito, faz-se necessário responder aos seguintes questionamentos: A inclusão de um novo tipo societário poderia ser feita por uma Medida Provisória? Esse novo tipo de sociedade unipessoal foi estabelecido a partir dos moldes portugueses? A figura da EIRELI, criada em 
2011, já não é suficiente? Para tanto, utilizou-se pesquisa qualitativa e bibliográfica, partindo da discussão do procedimento legislativo utilizado pelo governo para alteração do artigo 1052 do Código Civil, sua aplicabilidade e constitucionalidade, posteriormente, a verificação da influência ou não do modelo de empresas português para a inclusão da sociedade unipessoal e, por fim, as consequências para a EIRELI e para o direito empresarial.

Palavras - Chave: MP 881/2019. Lei n 13.874/2019. Sociedade Unipessoal.

Abstract: This paper aims to discuss the modification on Civil Code's art. 105, by means of the Provisional Measure of Economic Freedom (MP 881/2019), converted into Law No. 13.874/2019. The law adds the paragraphs 1 and 2 to the article, providing for the creation of sole proprietorship. On this matter, it is necessary to answer the following questions: Could the inclusion of a new corporate type be made by a Provisional Measure? Was this new type of sole proprietorship based on Portuguese molds? Is the figure of EIRELI, created in 2011, no longer enough? For that, a qualitative and bibliographic research was used, starting from the discussion of the legislative procedure used by the government to amend Civil Code's article 1052, its applicability and constitutionality, subsequently, the verification of the influence or not of the Portuguese business model for inclusion of sole proprietorship and, finally, their consequences for EIRELI and corporate law.

Keywords: pm 881/2019. Law n. 13.874/2019. Sole Proprietorship.

\section{INTRODUÇÃO}

O presente trabalho busca tecer considerações a respeito das alterações efetivadas no Código Civil por meio da Medida Provisória da Liberdade Econômica (MP 881/2019), convertida na Lei da Liberdade Econômica - LLE (Lei nº 13.874/2019).

O Presidente da República editou, em 30 de abril de 2019, a Medida Provisória nº 881, que institui a Declaração de Direitos de Liberdade Econômica. Trata-se, segundo o próprio Governo Federal, de tentativa de superação da estagnação econômica e das altas taxas de desemprego, notadamente por meio da redução da burocracia necessária para pequenos e médios empreendedores desenvolverem suas atividades.

De acordo o artigo $1^{\mathrm{a}}$ da Medida Provisória, "fica instituída a Declaração de Direitos de Liberdade Econômica, que estabelece normas de proteção à livre iniciativa e ao livre exercício de atividade econômica e disposições sobre a atuação do Estado como agente normativo e regulador".

Dentre as várias alterações estabelecidas, escolheu-se discutir a alteração prevista para o artigo art. 1052, CC, a qual inclui um novo tipo de sociedade unipessoal.

Neste contexto, o problema desta pesquisa gira em torno de uma série de questionamentos, tais como: A inclusão de um novo tipo societário, mudança relevante, poderia 
ser feita por uma Medida Provisória? Esse novo tipo de sociedade unipessoal foi estabelecido a partir dos moldes portugueses? A figura da EIRELI, criada em 2011, já não é suficiente?

Desta maneira, a fim de responder tais questões, será necessário refletir se a alteração prevista para o artigo art. 1052, CC, acarretará pontos positivos ou negativos para o direito empresarial, com o fito de garantir direitos e propiciar transformação social.

A pesquisa é qualitativa e bibliográfica, sendo que a discussão começa pautada no procedimento legislativo utilizado pelo governo para alteração do artigo 1052, do Código Civil, averiguando sua aplicabilidade e constitucionalidade, posteriormente, verificou-se, se houve ou não, influência do modelo de empresas português para a inclusão da sociedade unipessoal, por fim, analisaram-se as consequências para a EIRELI e para o direito empresarial.

\section{ALTERAÇÃo do Código CIVIL POR MEIO DA MEDIDA PROVISÓRIA 881/2019}

Conforme já mencionado, em final de abril de 2019, o Presidente da República editou a Medida Provisória n ${ }^{\circ}$ 881, que instituiu a Declaração de Direitos de Liberdade Econômica, alterando diversos artigos do Código Civil Brasileiro.

Segundo a Constituição Federal em seu art. 62, a medida provisória "é ato monocrático do Presidente da República com força de lei, editada em caso de relevância e urgência, devendo ser imediatamente submetida ao Congresso Nacional”. (BRASIL, 1988)

Para Bulos a justificativa da edição de medidas provisórias pelo Presidente da República com força de lei:

[...] é a existência de um estado de necessidade, que impõe ao Poder Público a adoção imediata de providências, de caráter legislativo, inalcançáveis segundo as regras ordinárias de legiferação, em face do periculum in mora que fatalmente decorreria do atraso na concretização da prestação legislativa. (BULOS, 2008, p. 982) (grifo do autor).

Neste sentido, observa-se que as medidas provisórias são instrumentos excepcionais, que devem ser utilizados apenas em casos de relevância e urgência, que justificam sua edição.

Ademais, para Bulos (2008), tais atos normativos são medidas excepcionalíssimas, pois afastam temporariamente o princípio da separação dos poderes, indispensáveis para a manutenção do Estado Democrático de Direito.

A Medida Provisória produz efeitos imediatos, porém, depende de aprovação do Congresso Nacional para transformação definitiva em lei. Seu prazo de vigência é de sessenta dias, prorrogáveis uma vez por igual período. Se não for aprovada no prazo de 45 dias, contados 
da sua publicação, a Medida Provisória tranca a pauta de votações da Casa em que se encontrar (Câmara ou Senado) até que seja votada.

Ao chegar ao Congresso Nacional, é criada uma comissão mista, formada por deputados e senadores, para aprovar um parecer sobre a Medida. Depois, o texto segue para o Plenário da Câmara e, em seguida, para o Plenário do Senado.

Se a Câmara ou o Senado rejeitar a MP ou se ela perder a eficácia, os parlamentares têm que editar um decreto legislativo para disciplinar os efeitos jurídicos gerados durante sua vigência. Caso o conteúdo de uma Medida Provisória seja alterado, ela passa a tramitar como projeto de lei de conversão.

Depois de aprovada na Câmara e no Senado, a Medida Provisória - ou o projeto de lei de conversão - é enviada à Presidência da República para sanção. O presidente tem a prerrogativa de vetar o texto parcial ou integral, caso discorde de eventuais alterações feitas no Congresso.

Neste contexto surge a seguinte indagação: qual a relevância e urgência de alterar o art. 1052 do Código Civil por meio de Medida Provisória?

A princípio, podem-se verificar dois posicionamentos opostos a tal questão. Os que não vislumbram a relevância e a urgência da inclusão de novo tipo de sociedade limitada unipessoal, devendo a alteração de o Código Civil ser feita por meio de projeto de lei, observando o quórum para aprovação de lei ordinária, mesma natureza do Código Civil. Segundo este posicionamento, a Medida provisória não é lei antes de ser convertida em lei, logo, segundo a Constituição Federal não poderia alterar lei ordinária (Código Civil).

Outra questão que corrobora com esse primeiro entendimento é que no Brasil, apesar da Constituição Federal estabelecer que a Medida Provisória tem validade de 60 (sessenta) dias, podendo ser prorrogada por mesmo período, tem-se casos de Medida Provisória, que foram reeditadas diversas vezes, como a Medida Provisória 2170/01, que foi reeditada mais de 15 vezes, perdurando anos, uma afronta ao art. 62 da Constituição Federal. E, se o mesmo ocorresse com a Medida Provisória da Liberdade Econômica acarretaria instabilidade jurídica.

Por outro lado, há aqueles que defendem a relevância e a urgência da inclusão de novo tipo de sociedade limitada unipessoal, sob dois argumentos; primeiro, a Constituição Federal não impede o tratamento desta matéria por Medida Provisória; segundo, ante a inércia do Congresso Nacional para alterar o quadro econômico do país, cabe ao poder executivo fazê-lo.

Neste sentido, opta-se por aderir ao primeiro posicionamento, vez que o incentivo à criação de sociedade limitada de um sócio, mesmo no contexto de fomento à economia 
brasileira, não é caso de relevância e urgência, que legitimam o uso da Medida Provisória pelo poder executivo federal.

A relevância é o pressuposto relacionado à essência da Medida Provisória, para editála, é indispensável que sua formulação seja relevante e que sua falta acarrete uma situação de desordem, uma iminência de desgoverno ou dano social ou econômico.

Quanto à urgência trata-se daquilo que a sua abstenção acarretará dano irreparável ou de difícil reparação, não podendo ser adiada. Nesse sentido assevera Celso Antônio Bandeira de Mello:

[...] mesmo que a palavra contenha em si algum teor de fluidez, qualquer pessoa entenderá que só é urgente o que tem de ser enfrentado imediatamente, o que não pode aguardar o decurso do tempo, caso contrário o benefício pretendido inalcançável ou o dano que se quer evitar consumar-se-á ou, no mínimo existirão sérios riscos de que sobrevenha efeitos desastrosos em caso de demora. (MELLO, 2006, p. 118).

Apesar das críticas e levantamento da tese de inconstitucionalidade da Medida provisória, sob o argumento de não observar as exigências do art. 62, da Constituição Federal, esta foi remetida ao Congresso Nacional e, depois de sofrer alterações, converteu-se na Lei $\mathrm{n}^{\circ}$ 13.874/2019, publicada em 20 de setembro de 2019.

\section{CONVERSÃO DA MEDIDA PROVISÓRIA 881/2019 NA LEI DA LIBERDADE ECONÔMICA - LLE (LEI No 13.874/2019)}

Durante o processo legislativo para a conversão da Medida Provisória nº 881/2019 na Lei da Liberdade Econômica - LLE (Lei $\mathrm{n}^{\mathrm{o}}$ 13.874/2019) -, muitos foram os debates estabelecidos não só entre os parlamentares, mas também entre juristas e estudantes de direito, o que pode ser validado com o alto número de produções acadêmicas relacionadas a este assunto.

Destaca-se também a quantidade de emendas à medida provisória $\mathrm{n}^{\mathrm{o}}$ 881/2019, totalizando 301 (trezentas e uma) propostas. Para muitos, esta quantidade tem origem na participação efetiva de respeitados juristas com críticas e sugestões que contribuíram para a redação final da LLE, como por exemplo, os doutrinadores Flávio Tartuce, Marco Aurélio Bezerra de Melo, Anderson Schreiber, Mário Delgado e Pablo Stolze, os quais influenciaram diretamente algumas emendas parlamentares, a exemplo das emendas nº 114 e 166.

A emenda $n^{\circ} 114$ trata da desconsideração da personalidade da pessoa jurídica enquanto que a emenda $n^{\circ} 166$ de mudança terminológica para adequar-se ao Código Civil, 
estabelecendo pequeno ajuste técnico no inciso II, letra $b$, do art. $3^{\circ}$ da MP para que conste a expressão "propriedade", e não "domínio".

Quanto ao assunto deste trabalho, estabelecimento da sociedade unipessoal, foram propostas 3 (três) emendas $n^{\circ} 142,175$ e 293. As emendas $n^{\circ}$. 142 e 175 pleiteavam a supressão de todo o art. $7^{\circ}$ da Medida Provisória, ou seja, exclusão da sociedade unipessoal. Já a emenda $\mathrm{n}^{\circ} .175$ prescrevia o traslado de conteúdo do parágrafo único do art. 1.052 como $\S 2^{\circ}$ do art. 981, ambos da Lei n ${ }^{\circ}$ 10.406, de 10 de janeiro de 2002 (Código Civil).

A tramitação no Congresso Nacional iniciou-se no dia 30 de abril de 2019, com envio à Secretaria Legislativa do Congresso Nacional, aguardando designação membros da comissão mista parlamentar.

Designada, em 3 de maio de 2019, a Comissão mista com a finalidade de emitir parecer sobre a matéria, composta por Presidente, Senador Dário Berger (MDB/SC); Vice-presidente, Deputado Marco Bertaiolli (PSD/SP); Relator, Deputado Jerônimo Goergen (PP/RS) e, por fim, Relatora Revisora, Senadora Soraya Thronicke (PSL/MS).

Em 19 de julho de 2019, a Secretaria de Expediente encaminhou a Medida Provisória para apreciação da Câmara dos Deputados, sendo remetida no dia 15 de agosto de 2019 para o Senado Federal, pela mesa da Câmara dos Deputados.

A Secretaria de atas e diários, no dia 21 de agosto de 2019, encaminhou à publicação a aprovação do projeto de lei de conversão, sendo feita a comunicação à Câmara dos Deputados.

No dia 20 de setembro de 2019, o Presidente da República sancionou a Lei ${ }^{\circ}$ 13.874/2019, com os seguintes vetos: art. $3^{\circ}$, inciso VII; alínea $a$ do inciso XI do art. $3^{\circ}$; art. $3^{\circ}$, $\S 9^{\circ}$; art. 19, Inciso IV; art. 20, Inciso I da Lei n $^{\circ} 13.784 / 2019$.

Quanto à vigência da Lei da Liberdade Econômica, algumas palavras são importantes: o veto presidencial do inciso I, do art. 20, que estabelecia prazo de vacatio legis de 90 dias para os arts. $6^{\circ}$ ao 19 , sob o argumento que:

\begin{abstract}
A propositura legislativa, ao estabelecer o prazo de noventa dias para a entrada em vigor dos arts. $6^{\circ}$ ao 19 do projeto de lei, contraria o interesse público por prorrogar em demasia a vigência de normas que já estão surtindo efeitos práticos na modernização do registro público de empresas, simplificação dos procedimentos e adoção de soluções tecnológicas para a redução da complexidade, fragmentação e duplicidade de informações, entre outros. Nestes termos, deve prevalecer a norma do inciso II do art. 20, que estabelece a vigência imediata do projeto de lei, na data de sua publicação. (MENSAGEM No 438, 2019).
\end{abstract}

Para Stolze, essas razões indicadas para veto do inciso I do art. 20 da LLE se contrapostas ao artigo $1^{\circ}$ da Lei de Introdução às Normas do Direito Brasileiro - LINDB, estabelecem um cenário curioso: 
Ora, se, de acordo com o inc. II, a vigência seria imediata "para os demais artigos", os artigos contemplados no inciso vetado (arts. $6^{\circ}$ ao 19), por consequência lógica, somente começariam a vigorar após a vacatio de 45 dias, conforme preceitua a regra geral constante no art. $1^{\circ}$ da Lei de Introdução às Normas do Direito Brasileiro - LINDB. (STOLZE, 2019).

Assim, com o veto do inciso I do art. 20 da LLE, a aplicação dos arts. $6^{\circ}$ ao 19 não seria imediatamente, por força normativa da Lei de Introdução às Normas do Direito Brasileiro, devendo-se esperar o lapso temporal de 45 dias.

Todavia, para Stolze (2019), a parte final das razões, conduz à ideia de que a intenção do Governo Federal, é da vigência imediata da lei, e, por ser mais prático esse entendimento, talvez prevaleça, a despeito de a redação do texto legal.

\section{A PROBLEMÁTICA ENVOLVENDO A SOCIEDADE EMPRESÁRIA UNIPESSOAL INSTITUÍDA PELA MP 881/2019}

A sociedade limitada é um dos tipos societários mais adotados no Brasil e, recentemente, passa por alterações legislativas.

Segundo Gonçalves Neto (2010, p. 314), a necessidade de criação deste tipo de sociedade foi percebida depois da Revolução Industrial de 1870; isso porque o mercado e as relações mercantis estavam se expandindo e necessitavam da criação de uma sociedade em que houvesse limite para a responsabilidade dos sócios, bem como exigisse menos formalidade para sua constituição e, portanto, maior rapidez. Assim, essas sociedades começaram a surgir no comércio inglês.

Elas adentraram no Brasil com o decreto 3.708/1919 e, atualmente, são instituídas pelo art. 1.052 do Código Civil (CC), que tem a seguinte redação: “Art. 1.052. Na sociedade limitada, a responsabilidade de cada sócio é restrita ao valor de suas quotas, mas todos respondem solidariamente pela integralização do capital social” (BRASIL, 2002).

A sociedade limitada é uma intermediária da sociedade de capital e da sociedade de pessoas. Ela deve ser formada por pelo menos duas pessoas, não tem a exigência de um capital mínimo e nem que este esteja totalmente integralizado já no momento da sua constituição; sua principal característica é a de que seus sócios respondem apenas pelas quotas que prometeram integralizar, e, se algum faltar com a sua parte, respondem solidariamente pela total integralização do capital social:

[...] a sociedade limitada tem condições de ser definida como a sociedade empresária, de natureza contratual e intuito personae, cujos sócios não respondem pelas obrigações sociais, obrigando-se, tão somente, pelo 
pagamento de suas quotas e pela efetiva integralização do capital social, por falta de realização da totalidade de entradas prometidas pelos sócios e pelo excesso de valor atribuído a bens aportados para sua formação. (GONÇALVES NETO, 2010, p. 317).

A Medida Provisória 881/2019 (MP da liberdade econômica) acrescentou um parágrafo único no art. 1.052, criando a figura da sociedade limitada unipessoal no direito brasileiro: "A sociedade limitada pode ser constituída por uma ou mais pessoas, hipótese em que se aplicarão ao documento de constituição do sócio único, no que couber, as disposições sobre o contrato social” (BRASIL, 2019a). Essa redação foi alterada e se mantém assim na Lei n $13.874 / 2019$ (Declaração de Direitos de Liberdade Econômica): "§1º A sociedade limitada pode ser constituída por 1 (uma) ou mais pessoas. $\S 2^{\circ}$ Se for unipessoal, aplicar-se-ão ao documento de constituição do sócio único, no que couber, as disposições sobre o contrato social. (BRASIL, 2019)".

A sociedade empresária unipessoal é inspirada na sociedade limitada, mas, ao contrário desta, tem por característica fundamental ser constituída por uma única pessoa/sócio. Além disso, terá patrimônio autônomo em relação ao patrimônio pessoal deste sócio, conforme ocorre nas sociedades limitadas. Coutinho de Abreu (2009, p. 21) considera que uma sociedade pode ser constituída por um ou mais sócios: "[sociedade é] a entidade que, composta por um ou mais sujeitos (sócio(s)), tem um patrimônio autônomo para o exercício de atividade econômica que não é de mera fruição, a fim de (em regra) obter lucros e atribuí-los ao(s) sócio(s) - ficando este(s), todavia, sujeito(s) a perdas" (apud TOMAZETTE, 2016, p. 58).

Essa mudança, inserida pela lei, divide opiniões. Alguns teóricos consideram que essa nova modalidade de sociedade é positiva, fomentando a atividade empresarial no Brasil através de uma desburocratização, inclusive por não haver exigência de capital mínimo para sua constituição. Flávio Tartuce adota este posicionamento:

Com o devido respeito a quem critica, não vejo assim. A nova modalidade de sociedade não cria qualquer problema, apenas valoriza a autonomia privada e representa mais uma saudável tentativa de redução de burocracias para a constituição de pessoas jurídicas no Brasil. Além disso, não vejo qualquer lesão à norma de ordem pública no texto proposto pela Medida Provisória. E mais, a sociedade limitada unipessoal não sofrerá restrições existentes para a EIRELI, como a exigência de capital social mínimo de 100 salários mínimos e de vedação de uma mesma pessoa intitular mais de uma pessoa jurídica dessa forma (art. 980-A, caput e $\S 1^{\circ}$, CC). (TARTUCE, 2019).

Ademais, segundo Carlos Eduardo Elias de Oliveira, a sociedade unipessoal aplica-se aos profissionais liberais, bem como possui regras mais claras:

Em paralelo com a Eireli, o art. 1.052 do CC passa a admitir que a sociedade limitada possa ser unipessoal. Embora, numa primeira análise, pareça haver 
uma redundância, é preciso atentar para o fato de que o LLE não extinguiu a Eireli para poupar os atuais empresários de transtornos burocráticos com a transformação dessa pessoa jurídica em sociedade limitada unipessoal. Convém, porém, que os atuais titulares de Eireli busquem essa transformação, pois as regras de sociedade limitada são mais claras. Além do mais, atividades de profissionais liberais, que, em princípio, não poderiam ser formalizadas por meio de Eireli (que, em tese, se restringe a atividades empresariais), podem agora assumir um formato societário unipessoal sem inseguranças normativas por meio de uma sociedade limitada unipessoal (que pode ser empresária ou simples). (OLIVEIRA, 2019).

Na contramão desse pensamento, alguns doutrinadores argumentam que a pluralidade de sócios é um pré-requisito para a constituição de uma sociedade. Admitir a existência de uma sociedade formada por um único sócio seria ir contra os princípios de direito societário. Pontua Marlon Tomazzete:

Todavia, tal solução é questionável na sua própria concepção. Não há dúvida de que a pluralidade de sócios não significa reforço para os credores, mas sem sombra de dúvida a pluralidade é uma exigência inerente ao funcionamento orgânico das sociedades, pois afasta a ideia de affectio societatis, a expressão de uma vontade social e especial a existência de um interesse social. A própria ideia de agrupamento que é diretamente ligada a de sociedade seria desvirtuada. Haveria um desvirtuamento das regras do direito societário para essa limitação de riscos, a qual não é necessária nesse caso, pela existência de outras técnicas. (TOMAZETTE, 2016, p. 58-59)

Isso acontece porque a única forma de sociedade unipessoal admitida no Brasil até então (além da sociedade subsidiária integral, prevista na Lei $n^{\circ}$ 6.404/76) se dava quando uma sociedade limitada se dissolvia, ficando com um único sócio, caso em que este deveria, no máximo em 180 dias, reconstituir a pluralidade de sócios ou converter a sociedade em EIRELI ou em empresário individual:

Art. 1.033. Dissolve-se a sociedade quando ocorrer:

[...] IV - a falta de pluralidade de sócios, não reconstituída no prazo de cento e oitenta dias;

[...] Parágrafo único. Não se aplica o disposto no inciso IV caso o sócio remanescente, inclusive na hipótese de concentração de todas as cotas da sociedade sob sua titularidade, requeira, no Registro Público de Empresas Mercantis, a transformação do registro da sociedade para empresário individual ou para empresa individual de responsabilidade limitada, observado, no que couber, o disposto nos arts. 1.113 a 1.115 deste Código. (BRASIL, 2002).

Outro argumento contra a sociedade empresária unipessoal pauta-se na ideia de que já existe um modelo empresarial composto por uma única pessoa e que tem responsabilidade limitada. Esse modelo corresponde à EIRELI (Empresa Individual de Responsabilidade Limitada), que teria sua aplicabilidade e efetividade colocadas em xeque pela alteração normativa. 
A EIRELI foi incluída no ordenamento jurídico brasileiro pela Lei ${ }^{\circ} 12.441 / 2011$ e corresponde a uma figura jurídica em que uma única pessoa é titular de todo o capital social e em que existe responsabilidade limitada, separando o patrimônio do titular do patrimônio da EIRELI (art. 980-A, $\S 7^{\circ}, \mathrm{CC}$ ). A EIRELI não é uma sociedade, trata-se de uma nova pessoa jurídica, com características peculiares, que visa estimular o empreendedorismo:

[...] o direito criou técnicas de limitação de responsabilidade para incentivar o desenvolvimento da própria economia, incentivando que as pessoas apliquem seus recursos em atividades econômicas produtivas, sem, contudo, correr riscos extremos de perda de seu patrimônio [...] Nesta técnica, o que se faz é "atribuir personalidade jurídica à empresa individual, a fim de congregar, em torno de sujeito de direito, diverso da pessoa do empresário, as relações jurídicas emergentes da atividade empreendedora", vale dizer, "a criação legislativa da empresa individual de responsabilidade limitada, como sujeito de direito, importaria, necessariamente, na instituição de uma nova classe de pessoa jurídica de direito privado". (TOMAZETTE, 2016, p. 56-63).

O que difere a EIRELI da sociedade empresária unipessoal, além do fato de não constituir uma sociedade, é que a EIRELI possui uma série de requisitos, enquanto a sociedade unipessoal quase não faz exigências. Primeiramente, a EIRELI exige um capital social mínimo de 100 vezes o maior salário-mínimo vigente no Brasil (art. 980-A, CC), enquanto a sociedade unipessoal não exige capital mínimo. Além disso, cada pessoa natural pode constituir apenas uma EIRELI (art. 980-A, §2, CC). Dessa maneira, realmente a sociedade empresária unipessoal parece mais “descomplicada”, o que levanta a questão se a EIRELI cairá em desuso, pois, apesar de possuir responsabilidade limitada, possui uma série de requisitos desnecessários para a constituição de uma sociedade unipessoal que também preserva o patrimônio pessoal de seu titular.

\section{BREVE EVOLUÇÃO HISTÓRICA DA SOCIEDADE UNIPESSOAL NO ÂMBITO DO DIREITO EUROPEU E SUA INFLUÊNCIA PARA O DIREITO BRASILEIRO}

Finalmente, cabe esclarecer da onde vieram as influências para a criação da sociedade empresária unipessoal através da Medida Provisória 881/2019.

No direito europeu a sociedade unipessoal já é utilizada há algum tempo, encontrando respaldo, inclusive, em legislação própria da União Europeia. Essa regulamentação se deu em 1989 pela XII Diretiva do Conselho da Comunidade Europeia, visando, principalmente, através da publicidade dos atos, dar garantia aos credores.

Destaca-se aqui, no âmbito da comunidade europeia, a diretiva 86/667/CEE que pretendeu uniformizar o tratamento da disciplina naquele contexto europeu. Contudo, esclarece-se, desde já, que alguns países da comunidade europeia já admitiam e possuíam legislação permitindo a constituição originária da sociedade unipessoal. Menezes Cordeiro adverte-nos que na 
década de 1980, a situação na Europa era bastante dispersa: alguns países admitiam a unipessoalidade originária; em outros, era proibida e em outros, ignorada. (MOREIRA, 2016, p. 72).

O primeiro país a adotar a sociedade unipessoal na Europa foi a Alemanha em 1980. Além dela, vale citar a experiência da França (1985) e da Espanha (1995):

Dentre os países da CEE, o ordenamento jurídico alemão foi o primeiro a permitir, no ano 1980, a constituição das sociedades unipessoais, consagrando esse mecanismo como melhor forma de proceder à limitação do comerciante individual e harmonizar a realidade jurídica ao que, de fato, era recorrente na prática comercial. [...] [Na França] Por meio da Lei no 85.697, de 11 de julho de 1985, institui-se a forma societária para proteção ao exercício da empresa individual originária, consentindo a constituição de uma sociedade limitada por uma ou várias pessoas; no que concerne à unipessoalidade superveniente deixou de prever o prazo para fins de reconstituição da pluralidade de sócios. [...] Em Espanha, assim como em outros ordenamentos, a unipessoalidade societária, originária ou superveniente, era inicialmente negada, diante da exigência de pluralidade social; após esse período, a concentração das participações sociais nas mãos de um único sócio passou a ser temporariamente admitida; a partir de 1995, passou-se a admitir a constituição originária de uma sociedade unipessoal, consagração legislativa trazida ao ordenamento espanhol pela Lei 2/1995, de 23 de março. (MOREIRA, 2016, p. 74-77).

Dentre os países da comunidade europeia, Portugal foi o que se manteve mais relutante a adotar a sociedade empresária unipessoal. Arraigado na ideia de sociedade contratual, não admitia sociedade unipessoal nem em caso de superveniência, ou seja, aqueles em que os demais sócios houvessem saído da sociedade, caso em que deveria ser resolvida imediatamente: "A doutrina tradicional portuguesa durante muito tempo não admitia a existência da sociedade unipessoal, seja ela surgida em dado momento da vida da sociedade existente, cuja consequência seria sua dissolução imediata, seja a unipessoalidade social originária" (MOREIRA, 2016, p. 62). Depois de um tempo, a sociedade unipessoal superveniente passou a ser admitida.

Em 1986, Portugal avançou criando a figura do EIRL (Estabelecimento Individual de Responsabilidade Limitada), figura assemelhada à EIRELI, com exigência, inclusive, de capital social mínimo, mas que não teve uma grande adesão: “É de se reconhecer que a legislação do EIRL é complexa e extensa. As críticas doutrinárias ao instituto foram variadas e intensas. $\mathrm{Na}$ prática, a figura não societária não foi bem recepcionada" (MOREIRA, 2016, p. 65).

Depois do insucesso do EIRL o ordenamento jurídico português admitiu a criação da sociedade unipessoal por quotas, que está presente no art. $270^{\circ}$ - A do Código das Sociedades Comerciais Português: “A sociedade unipessoal por quotas é constituída por um sócio único, 
pessoa singular ou colectiva, que é o titular da totalidade do capital social." (DL n. ${ }^{\circ}$ 262/86, de 02 de Setembro).

Dessa forma, percebe-se que a adesão do Brasil à sociedade unipessoal tem grande influência do direito europeu, sobretudo português, por enfrentar os mesmos questionamentos e relutâncias quanto a adotá-la, salientando que o Brasil demorou muito mais tempo para aceitar a previsão das sociedades empresárias unipessoais.

\section{CONSIDERAÇÕES FINAIS}

A exposição e a testagem dos argumentos dispostos no artigo confirmam que a inclusão de um novo tipo societário no Código Civil Brasileiro não poderia ser feita por uma medida provisória. Apesar de ser matéria relevante, falta-lhe o outro requisito de admissibilidade/aplicabilidade, qual seja, a urgência.

Contudo, é importante dispor que este primeiro questionamento perde relevância, haja vista a conversão da Medida Provisória $n^{\circ}$ 881/2019 na Lei nº ${ }^{\circ}$ 13.784/2019, após apreciação do Congresso Nacional e sanção do Presidente da República.

Demonstrou-se que o tipo de sociedade unipessoal é amplamente utilizado pelo direito europeu e, que, o direito português foi o paradigma para o governo federal quando da propositura da medida provisória.

Neste contexto social, a EIRELI já não é suficiente para garantir direitos, devido a obscuridade de seu regramento. Ademais, por meio da sociedade unipessoal poderá regular as atividades de profissionais liberais, que, em princípio, não poderiam ser formalizadas por meio de EIRELI (que, em tese, se restringe a atividades empresariais).

Por fim, percebe-se que o Parlamento Brasileiro desempenhou bem suas funções nas discussões inerentes a conversão da Medida Provisória 881/2019 e no aperfeiçoamento do texto. Quanto ao acréscimo dos parágrafos $1^{\circ}$ e $2^{\circ}$ do art. 1052 do Código Civil, pensa-se que é um avanço no que tange a possiblidade de regulamentação das atividades de profissionais liberais, bem como a legislação aplicável a sociedade unipessoal é mais clara que as normas da EIRELI, o que favorece a tutela dos direitos.

\section{REFERÊNCIAS}

BRASIL. Lei no 10.406, de 10 de janeiro de 2002. Código Civil. Disponível em: http://www.planalto.gov.br/ccivil_03/leis/2002/110406.htm. Acesso em: 20 set. 2019. 
BRASIL. Lei $\mathbf{n}^{\mathbf{0}}$ 13.874, de 20 de setembro de 2019. 2019b. Disponível em: http://www.in.gov.br/en/web/dou/-/lei-n-13.874-de-20-de-setembro-de-2019-217365826. Acesso em: 20 set. 2019.

BRASIL. Medida Provisória no 881, de 30 de abril de 2019. 2019a. Disponível em: https://legis.senado.leg.br/sdleggetter/documento?dm=7946806\&ts $=1564416807591 \&$ disposition=inline. Acesso em: 20 set. 2019.

BULOS, Uadi Lammêgo. Curso de Direito Constitucional. 2a . ed. São Paulo: Saraiva, 2008.

GAGLIANO, Pablo Stolze. A Lei no . 13.784/2019 (Lei da Liberdade Econômica).

Disponível em: https://flaviotartuce.jusbrasil.com.br/artigos/760054174/artigo-do-professorpablo-stolze-gagliano-sobre-a-lei-13784-2019-lei-da-liberdade-economica. Acesso em: 23 set. 2019.

GONÇALVES NETO, Alfredo de Assis. Direito de Empresa. $3^{\text {a }}$. ed. São Paulo: Editora Revista dos Tribunais, 2010.

MELLO, Celso Antônio Bandeira de. Curso de Direito Administrativo. 20ª ed. São PauloSP; Editora Malheiros, 2006.

MENSAGEM No 438. Vetos Projeto de Lei de Conversão n⿳0 21, de 2019 (MP no 881/19). Disponível em: http://www.planalto.gov.br/ccivil_03/_ato2019-2022/2019/Msg/VEP/VEP438.htm. Acesso em: 23 set. 2019.

MOREIRA, Wellinton Luiz. A Sociedade Unipessoal e a Limitação da Responsabilidade Patrimonial do Empresário Individual. Coimbra, 2016. Dissertação apresentada à Faculdade de Direito da Universidade de Coimbra no âmbito do $2^{\circ}$ Ciclo de Estudos em Direito (conducente ao grau de Mestre) na Área de Especialização em Ciências JurídicoEmpresariais/Menção: Direito Empresarial. Disponível em: https://estudogeral.sib.uc.pt/bitstream/10316/42503/1/Welliton\%20Moreira.pdf. Acesso em: 21 set. 2019.

OLIVEIRA, Carlos Eduardo Elias de. Lei da Liberdade Econômica: diretrizes interpretativas da nova Lei e Análise detalhada das mudanças no Direito Civil e nos Registros Públicos. Disponível em: http://www.flaviotartuce.adv.br/artigos_convidados Acesso em: 23 set. 2019.

PORTUGUAL. Decreto-Lei n ${ }^{\circ}$ 262/1986. Códigos das Sociedades Comerciais. Disponível em: https://dre.pt/legislacao-consolidada/-/lc/34443975/view. Acesso em: 21 set. 2019.

TARTUCE, Flávio. A Medida Provisória 881/2019 e as Alterações do Código Civil Segunda Parte: Teoria Geral dos Contratos, Direito de Empresa e Fundos de Investimento. 2019. Disponível em:

https://flaviotartuce.jusbrasil.com.br/artigos/705118554/a-medida-provisoria-881-2019-e-asalteracoes-do-codigo-civil-segunda-parte-teoria-geral-dos-contratos-direito-de-empresa-efundos-de-investimento. Acesso em: 20 set. 2019. 
TOMAZETTE, Marlon. Curso de Direito Empresarial - Teoria Geral e Direito Societário. 7. ed. São Paulo: Atlas, 2016. 


\title{
O USO DO PLANO DE NEGÓCIOS PARA ANÁLISE DE VIABILIDADE FINANCEIRA DE UM EMPREENDIMENTO ESPORTIVO
}

The use of the business plan for financial viability analysis of a sportive enterprise

\section{Gabriela Nunes de Oliveira}

\begin{abstract}
Graduação de Bacharel em Administração em andamento pela Universidade de Estado de Minas Gerais-UEMG/Frutal; Formada nos cursos de Bacharel em Esporte e Licenciatura em Educação Física pela Universidade de São Paulo - USP unidade Capital; Já atuou como Coordenadora da Produção da Seleção Brasileira de Paracanoagem no período preparatório para os Jogos Olímpicos realizados no Rio de Janeiro em 2016 dos nos de 2014 até 2016. Interessa-se por gestão esportiva no quesito de organizar eventos, e desenvolver equipes esportivas. Foi bolsista do "Programa de Bolsas do Programa de Incentivo e Suporte Técnico - A Universidade de São Paulo nos Jogos Olímpicos e Paraolímpicos 2016". Vice- Presidente da Gestão 2012 da Liga Atlética Acadêmica da USP (LAAUSP). E-mail: gabiesporte@gmail.com
\end{abstract}

Marildo Domingos da Silva

Professor da Universidade do Estado de Minas Gerais- UEMG/Frutal. Mestre em Ciência da Informação pela Pontifícia Universidade Católica de Campinas. Bacharel em Administração pelas Faculdades Integradas de Votuporanga. Experiência profissional de 25 anos na área de Administração, 11 anos de atuação profissional em consultoria empresarial na área financeira e 18 anos de atividades práticas relacionadas a docência no ensino superior (graduação e pós graduação), ênfase das atividades docentes em Administração Financeira, Contabilidade, Custos, Gestão de Projetos, Processos Organizacionais e Sistemas de Informação.

Resumo: Para esse estudo buscou-se informações sobre os processos da ferramenta planos de negócios, para identificar se um empreendimento esportivo com vertente diferente dos esportes comuns, seria financeiramente viável para sua instalação e manutenção, com retornos visando a lucratividade de sua atividade. Com dados levantados pelo desenho do Canvas e outras ferramentas administrativas, foi possível identificar público alvo desejado além das necessidades financeiras e prioridades de processos, que dão suporte e serão aprofundados pelas pesquisas de mercado a serem elaboradas. Como resultados prévios, existem indícios de sucesso da implementação do negócio em questão.

Palavras-Chave: Empreendimento; Esportivo; Finanças; Plano de negócios.

\begin{abstract}
To produce this paper, information about the business plans tool's processes were searched, to identify if a sports enterprise with a different aspect of the common sports would be financially viable for its installation and maintenance, with paybacks aiming to its activity's profit. Stem from data surveyed in Canvas design and other administrative tools, it was possible to identify desired target audience beyond the financial needs and process priorities, which support and will be entrenched by the market research to be elaborated. As previous results, there are signs of success of the implementation of the mentioned business.
\end{abstract}

Key-Words: Enterprise; Sportive; Finances; Business Plan. 


\section{INTRODUÇÃO}

Em pesquisa apresentada pelo Ministério do Esporte (2015) a qual foi realizada pelo IBGE no ano de 2013 aponta que o sedentarismo no Brasil, está diretamente relacionado à idade do indivíduo, onde quanto mais anos ele tiver, maior o percentual de sedentarismo. As informações dessa pesquisa, relatam que 69,8\% das pessoas que responderam, justificaram seu abandono em praticar esporte por falta de tempo em função das novas prioridades (trabalho, estudos, família).

FRANCO (2017) ${ }^{9}$ aponta que apesar da alta quantidade de sedentários revelados na pesquisa, aproximadamente um terço (32\%) dos brasileiros que são ativos, praticam suas atividades físicas em instalações pagas e estruturadas. Essa informação reforça uma das teorias desse estudo, que acredita no interesse e necessidade das pessoas frequentarem locais com suporte de treinamento adequado e seguro para a evolução dessa prática.

Pode-se dizer que, eles contribuem de forma relevante na rotina das pessoas, oferecendo mais opções de lazer após o trabalho, por isso é natural que nas grandes cidades, exista demanda e participação mais intensa, logo pode-se subentender que nas pequenas cidades, a população também venha usufruir desses benefícios, dentro das suas limitações e características particulares (OLIVEIRA, 2012).

Conforme aponta Pieron (2004), a busca pela prática esportiva é um componente crescente na sociedade, visto como uma ferramenta preventiva de doenças, um desenvolvedor de percepções sociais e formas de lazer. Fajersztajn, Veras e Saldiva (2016) definem a prática esportiva como um dos elementos a serem influenciados e influenciadores na promoção de saúde física e mental dos integrantes das comunidades.

Outro estudo, de grande relevância no ambiente acadêmico, publicado por Dietman Samulski e Franco Noce (2000), destaca os benefícios na saúde que a prática de atividade física e esportiva pode incorporar para o indivíduo ativo. O trabalho foi desenvolvido envolvendo 574 indivíduos, entre homens e mulheres de várias áreas da comunidade da UFMG. A comunidade amostral apresentou uma conclusão onde vincula que o conceito de saúde está fortemente associado à atividade física, expressados através dos termos “Qualidade de Vida” e "Bem-estar mental"'.

Quando se trata do tema empreendedorismo, existem fatores que são indispensáveis de serem pensados, e a criação de um plano de negócios é o ponto inicial para planejamento e visualização do todo. Ele é o desenvolvimento ordenado de um raciocínio sobre uma ideia ou

\footnotetext{
${ }^{9}$ Luiza Franco, psicóloga e colunista do jornal "Folha de São Paulo".
} 
ação de uma empresa. Através desse planejamento inicial, se torna possível delinear formas de identificar se existe ou não público suficiente para a continuidade e crescimento da atividade proposta pelo novo empreendimento (CECCONELLO, 2008).

Dentro dessa proposta, o estudioso Weber ${ }^{10}$, autor do primeiro trabalho relevante acerca de organizações formais, criou o que foi chamado de "modelo ideal, com o uso do que denominou na ocasião como burocracia que pregava que "a ação racional é aquela em que há adequação dos meios em relação aos fins que se quer atingir" aponta Teixeira (2010). Com o passar do tempo, entendeu-se que Weber acreditava que um modelo ideal, construído de forma conceitual era necessário, para contribuir na explicação dos mecanismos básicos e identificar eles, mesmo que na prática esse modelo não fosse fiel ao modelo ideal. Com isso, a racionalização das necessidades a serem pensadas em um procedimento de criação de um novo empreendimento, na construção do plano de negócios, estão inteiramente em conformidade com o que o que se pretende realizar com esse estudo.

Neste contexto o presente estudo pretende, através de uma reflexão direcionada, construir um plano de negócios, onde uma empresa com o viés esportivo, seja bem-sucedida em uma pequena cidade, oferecendo a possibilidade de desenvolver as atividades de forma atraente e contínua para a comunidade presente que estiver disposta a participar e a pagar pelo serviço.

\section{REVISÃO DA LITERATURA}

\subsection{O plano de negócios - Concepção da Ideia}

A ferramenta Plano de Negócios por conter instrumentos que antecipam a visualização das necessidades, possibilita uma análise do planejamento a curto, médio e longo prazos, contribuindo assim, no acompanhamento do desenvolvimento da empresa, para compreender se a mesma encontra-se no caminho desejável, e auxiliar o gestor em suas tomadas de decisões.

A ideia básica, que está por trás da elaboração de um Plano de Negócio, é oferecer ao tomador de decisões indicadores consistentes que apresentem o dimensionamento potencial dos ganhos, ou a minimização de perdas, frente aos riscos inerentes do negócio em análise. (CECCONELLO E AJZENTAL, 2008, p.3).

Dentre as várias demandas que um plano de negócios precisa atender, a verificação da localização ser ou não adequada, é uma das primeiras ações que precisam de atenção, pois

\footnotetext{
${ }^{10}$ Segundo Frazão (2018) Weber M., foi um grande e importante sociólogo e economista alemão, que se dedicou e destacou nos estudos sobre economia, tema de sua tese de doutorado. Trouxe a tona assuntos acerca dessa temática, é um grande influenciador até a atualidade no que diz respeito de analise de modelos e estudos sobre economia e capitalismo, apontando as questões socíais 12000 grandes influenciadores.
} 
podem antever a possibilidade de não sucesso do investimento. Para aumentar as chances de negócio em uma cidade pequena, será necessário levar em consideração vários aspectos de forma detalhada, e levantar formas práticas e viáveis para desenvolver ações, com propostas de sanar as dificuldades ou obstáculos que surgirem através do olhar crítico da pesquisa, conforme aponta Eric Cohen11, observando que o ideal é o empreendedor fazer um levantamento de informações sobre a localização, a fim de estabelecer as características sócio demográficas do mercado na área na qual tem o interesse em se instalar. (SOUZA, 2008).

Em complemento ao exposto anteriormente, Souza (2008), ainda destaca que para isso deve-se inicialmente levantar os dados quantitativos de número de moradores, percentual de perfil dos moradores no quesito gênero, idade, condição financeira, e através do apontamento dessas informações, será possível definir e direcionar o público-alvo para o empreendimento, com maiores condições de sucesso.

Mas esse detalhamento inicial, não é o suficiente. Apesar de ser o primeiro passo, é essencial observar e compreender o contexto em que a empresa estará inserida. Nesse processo inicial é quando se encontra diagnósticos dos ambientes micro (demanda e oferta, e as preferências e motivos dos clientes) e macro (influências) em que a empresa estará incluída, sendo observado os aspectos pertinentes para visualizar o sucesso sobre o negócio. Pode ser considerado um processo de pesquisa exploratória12 para se conhecer as particularidades do negócio dentro do espaço que será criado (CECCONELLO, 2008).

Diante do exposto o Plano de Negócios, deve ajudar a compreender o contexto e abrange conhecer a demanda e a oferta, o sistema de valor, a atratividade da indústria através da ferramenta Modelo das forças de Porter13 ou "modelo das 5 forças", verificar a condição de possíveis parcerias estratégicas, as questões sociais e políticas do local inserido, concorrências locais diretas e indiretas.

Feito o levantamento do contexto, surge o momento de discorrer sobre as hipóteses e variáveis desse negócio (concepção do negócio), que já irão apontar os propósitos construindo estratégias viáveis. É aqui que se introduz o pensar sobre as cadeias de valores, capital inicial e estrutura da empresa. (CECCONELLO, 2008 p. 140).

\footnotetext{
${ }^{11}$ Eric David Cohen, professor da UNICAMP, com vasto tempo de atuação e pesquisa na área de administração de empresas, sendo sua especialização em mercadologia.

${ }_{12}$ Pesquisa cujo objetivo e intuito é coletar informações ainda não conhecidas, ou identificadas formalmente, com o uso de análise controlada e direcionada para determinado assunto.

${ }^{13}$ Michael Porter, autor do livro "Estratégia Competitiva", que apesar de ter sido publicado na década de 80, ainda hoje é referência e um guia importante para os empreęzdedores já no mercado de trabalho a mais tempo, como também para os novatos.
} 
Uma vez desenhado o contexto, e identificado as particularidades do empreendimento, a criação do plano de negócios parte para os processos envolvendo as questões operacionais e estruturais, e o plano financeiro propriamente dito. Quais os custos necessários, para investimento inicial e manutenção, políticas de cobranças de mensalidades, definição de capital de giro e recursos para financiamento das atividades propostas, projeção de retorno dos investimentos, são alguns dos aspectos que dimensionam as operações acerca do empreendimento pensado. (CECCONELLO, 2008 p. 197).

De acordo Dornelas (2008, p.98), o Plano de Negócio é um “documento usado para descrever um empreendimento e o modelo de negócio que sustenta a empresa. Sua elaboração envolve um processo de aprendizagem e autoconhecimento, e, ainda, permite o empreendedor situar-se no seu ambiente de negócio.”. O SEBRAE14, também pontua que, um Plano de Negócios "descreve por escrito os objetivos de um negócio e quais passos devem ser dados para que esses objetivos sejam alcançados, diminuindo os riscos e as incertezas.”. Fica claro dessa forma, que o Plano de Negócios é uma ferramenta extremamente relevante para verificação e construção de um negócio, e essencial para nortear o desenvolvimento do trabalho.

Ainda oferecendo suporte para o Plano de Negócios, Cecconello (2008) sugere a utilização de outras ferramentas que podem facilitar a construção de partes da estrutura do Plano de Negócios, entre elas o "Canvas"15, Ansoff ${ }^{16}$, SWOT $^{17}$ e Forças Competitivas de Porter ${ }^{18}$.

A seguir serão apresentados maiores detalhes acerca de cada um dos componentes e ferramentas citados anteriormente. (Plano Financeiro, Mercado e Missão, visão e valores)

\subsection{O plano de negócios - Definição da Missão, Visão e Valores}

A definição faz parte dos componentes e tem importância por representar o desenho planejado da empresa, apontando características e princípios desde sua criação. Apesar de elas não serem fixas, podendo ser alteradas quando preciso, elas cumprem o propósito de nortear as decisões futuras, para que o empreendimento atue de forma coerente e focada com os propósitos.

\footnotetext{
${ }^{14}$ Serviço Brasileiro de Apoio às Micro e Pequenas Empresas (Sebrae) é uma entidade privada sem fins lucrativos.

15 O Canvas é uma ferramenta utilizada por empreendedores para visualizar os seus negócios de forma simples e prática.

${ }^{16}$ Matriz Ansoff é uma ferramenta que avalia o produto e o ambiente, apontando problemas ou oportunidades estratégicas decorrentes desse cruzamento dos dados desses dois elementos.

${ }^{17}$ SWOT resumidamente é uma ferramenta administrativa que trás a tona questões internas e externas da empresa apontando pontos fortes e fracos retacionado as esses ałzzłentes anatisados.

${ }^{18}$ Forças Competitivas de Porter, instrumento que "mede" as questões relacionadas ao poder e ameaças de uma empresa, no ambiente competitivo.
} 
Segundo OLIVEIRA (2007), para criar um empreendimento, deve-se inicialmente definir qual é a sua razão de ser, e essa definição dentro do processo de planejamento estratégico administrativo, é denominado de Missão da empresa.

Missão é a determinação do motivo central da existência da empresa, ou seja, a determinação de "quem a empresa atende". Corresponde a um horizonte dentro do qual a empresa atua ou poderá atuar. (OLIVEIRA, 2007, p.50)

O mesmo, em sua obra conceitua Visão como:

[...] os limites que os proprietários e principais executivos da empresa conseguem enxergar dentro de um período de tempo mais longo e uma abordagem mais ampla. Nesse contexto, a visão proporciona o grande delineamento do planejamento estratégico a ser desenvolvido e implementado pela empresa. A visão representa o que a empresa quer ser. (OLIVEIRA, 2007, p.65)

Por fim, o autor esclarece o conceito de Valores como sendo um "conjunto de princípios e crenças fundamentais de uma empresa, bem como fornecem sustentação para todas as suas principais decisões" (OLIVEIRA, 2007, p.67).

Tendo como base os conceitos acima, definir a missão, visão e valores da empresa, direciona o trabalho a fim de garantir que a empresa vislumbre e posicione as características a que quer se vincular perante a sociedade, e fortalece a linha de construção para que não se perca de vista esse posicionamento a longo prazo.

Assim pensando sobre qual é a razão de existência desse empreendimento que esta sendo estruturado, ou seja, sua missão, foi levado em consideração a priori uma observação de que existem poucos locais e poucas variedades de opções para práticas esportivas em estabelecimentos com estrutura, na cidade. Com essa constatação em destaque, a hipótese de minimizar essa falta foi criada e esta sendo desenvolvida através desse trabalho.

Como visão para empresa, seguindo a lógica explicada anteriormente, espera-se que a empresa se estabeleça financeiramente, para se manter ativa no mercado, e conseguir atender a demanda da população com interesses em práticas diferenciadas das comuns. Importante frisar, que nessa definição foi considerado os parâmetros para que a mesma seja clara, coerente, e realizável, conforme sugere Oliveira (2007).

Por fim, dentro do conceito dos valores apresentados, é muito importante que a empresa, reconheça seu papel dentro da sociedade, onde apesar de ser idealizada como empresa que visa obter lucros acerca de suas atividades desenvolvidas, a mesma garanta prover atividades físicas de qualidade, com segurança e paixão, propiciando aumento de valores culturais e de saúde física para a comunidade, cumprindo assim um importante papel de melhoria de qualidade de condição física e mental e cultural aos alunos e agregados familiares. 
Uma vez traçado os componentes delineadores da empresa missão, visão e valores, Cecconello aponta que "[...] o próximo passo é construir o conjunto de premissas, ou seja, o posicionamento estratégico, para possibilitar a verificação da viabilidade do negócio". (2008, p.156).

\subsection{O Plano Mercadológico}

A verificação do Plano de Marketing, surge com o intuito de trazer a tona como a empresa pretende apresentar e vender o seu serviço.

Através de uma pesquisa de mercado que desenha e busca informações do públicoalvo através de técnicas de pesquisas apropriadas, visando identificar os interesses e particularidades que são consideradas relevantes para a população que o empreendimento deseja alcançar, em qual serviço se deve investir, qual o preço que o cliente está disposto a pagar por esse serviço, quais os horários que deve-se oferecer o produto com maior intensidade para conseguir atender a demanda, quais tipos de promoções devem ser aplicadas entre outros.

Dentro da ideia de pesquisa do mercado, existe para nortear os processos e diretrizes do procedimento, o componente chamado Composto de Marketing, ou Mix de Marketing, ou ainda como será adotado neste artigo a nomenclatura de 4P`s do Marketing. Esse componente tem quatro pilares básicos que auxiliam a estratégia de marketing. São eles: Produto, Preço, Praça e Promoção.

De acordo com Kotler19, o equilíbrio desses elementos é o que possibilita o sucesso de uma marca ou empreendimento.

A verificação dos 4P`s, conforme sugere o autor citado acima, possibilita direcionar sobre qual prestação de serviço esse empreendimento deve-se investir (produto), se Frutal é o local que terá margens de sucesso (praça), para quem esse produto deve ser direcionado, para possibilitar definição do público-alvo, e consequentemente valores para os serviços (preço), e por fim, como ele pode ser exposto para atingir o máximo de pessoas possíveis interessadas e pagantes (propaganda).

Enfim, e será através da pesquisa de mercado que uma série de decisões mercadológicas, econômicas-financeiras, operacionais entre outras, relevantes para o empreendimento objeto deste estudo e que serão incorporadas aos cenários que comporão o plano financeiro para se atestar a viabilidade econômico-financeira.

\footnotetext{
${ }^{19}$ Philip Kotler, professor universitário dos EUA, estudioso na grande área de marketing, criador do conceito dos $4 \mathrm{P}$ s de Marketing.
} 


\subsection{O Plano Financeiro}

Segundo KALLER (2015), “O planejamento financeiro consiste em uma projeção de receitas e despesas para determinado período, análise do cenário projetado e determinação de metas com base nestas informações."

Esse componente do trabalho Plano de Negócios, conforme forem sendo identificadas as informações e os dados necessários e relevantes, apontará características de caráter financeiro desse empreendimento analisado, ser ou não característico de sucesso (viabilidade), através da construção de planilhas (tabelas), cruzando os dados para observação dos resultados relacionados a finanças propriamente dito.

Após a utilização das ferramentas necessárias para construção primária do plano de negócios, poder-se-á desenvolver o plano financeiro. Será através da construção do plano financeiro que serão geradas informações sobre as projeções futuras, e poderá então ter-se uma ideia de como será o fluxo de caixa, projetar um balanço patrimonial, verificação e análise de custos, de investimentos, previsão de retorno sobre o investimento e demais dados que dependam de números para análise.

Conforme aponta Gitman ${ }^{20}$ (1997, p.588), “as empresas utilizam-se de planos financeiros para direcionar suas ações com vistas a atingir seus objetivos imediatos e a longo prazo onde um grande montante de recursos está envolvido". Se trata de uma análise fundamental para aproximar o máximo da projeção de realidade financeira sobre uma empresa, seja ela nova no mercado, como é o caso do empreendimento objeto deste estudo, ou para analisar crescimento de uma já existente. É através dele que se torna possível manter um controle das finanças da empresa, caminhando para o êxito e saúde econômica da instituição, sendo essa uma grande característica de essencialidade da construção desse estudo do plano de finanças.

Através dele se construirá planilhas e gráficos com previsões sobre os investimentos, gastos. Ou seja, serão estruturadas projeções, com base nos dados obtidos advindos das outras partes do plano de negócios e de premissas estabelecidas a partir destes, formando o planejamento financeiro do empreendimento.

\subsection{O Plano de Negócios - Ferramentas Auxiliares}

\footnotetext{
${ }^{20}$ Lawrence Gitman, escritor da obra considerada como best-seller na administração, "Princípios de Administração Financeira" 
Com o foco em identificar quais as decisões mais importantes na criação de um negócio, Alexander Osterwalder21, desenvolvedor da ferramenta, aponta que a ferramenta Canvas é capaz de realizar gerenciamento estratégico, onde é permitido desenvolver e esboçar modelos novos ou existentes, com resultado de fácil visualização sobre o contexto geral do que compõe um empreendimento.

Sendo o ferramenta de apoio que permite desenhar todos os elementos do negócio em um único quadro de forma ampla, o Canvas foi pré-definido inicialmente, e através dos resultados de sua análise, as demais ferramentas de apoio terão suporte para serem aplicadas. Com uma natureza versátil e mutável, a cada etapa de desenvolvimento do trabalho, o Canvas permite ser alterado e ajustado conforme necessidade, tornando o mesmo muito adequado para fundamentar empreendimentos novos.

Outro recurso de apoio visado, é a ferramenta de análise ambiental "Matriz ProdutoMercado", que constrói informações através da coleta de dados relacionados ao mercado e ao produto, num contexto de ambiente externo, essencial para compreender onde o empreendimento esta estabelecido e qual a sua posição no mercado competitivo.

Através da análise da figura 1, localizado abaixo, é possível identificar a ambientação que se pretende criar o novo serviço com a utilizando dois vetores, o produto e mercado.

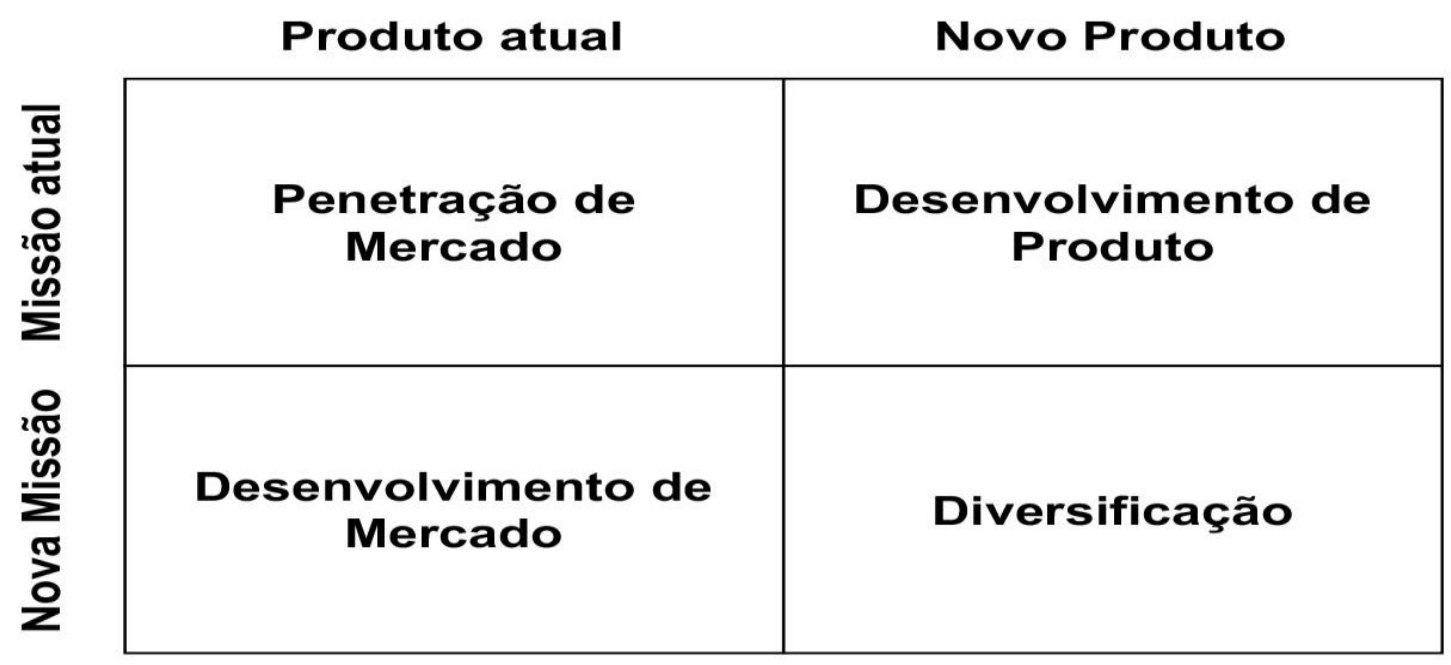

Figura 2: Matriz Missão/Produto de Ansoff

Fonte: Mintzberg, H.; Quinn, J.B., p. 92, 1996

21 Alexander OSTERWALDER, estudioso nascido na Suíça, que através do desenvolvimento de sua tese de doutorado, criou e desenvolveu a ferramenta "Business Model Canvas" no ano de 2011. 
De acordo com o autor e criador da ferramenta citada acima, Ansoff ${ }^{22}$, existem quatro situações de ambiente e mercado a serem considerados, para a tomada de decisões. Ela é utilizada para analisar e planejar suas estratégias empresariais.

A primeira situação é a denominada "penetração de mercado", em que os produtos e o mercado já existem, ou seja, nessa situação a sua empresa vai penetrar em uma situação com concorrentes. A segunda, é a chamada de "desenvolvimento de mercado", nesse caso já existe o produto, porém não nesse mercado que se pretende ingressar. Uma terceira situação é a "desenvolvimento do produto", cujo produto é novo, em um mercado já existem. Por fim, a quarta situação, que se considera a que encaixa esse empreendimento analisado, é a de "diversificação", que se trata tanto de um serviço como de um mercado inovador. (ELAINA, 2011)

Quando se posiciona a empresa e um quadrante dessa ferramenta, são sugeridas algumas ações a serem tomadas em busca do sucesso. Como por exemplo, uma empresa enquadrada na situação de diversidade, deve se envolver com empenho no quesito de publicidade, logo isso significa um investimento nesse mercado, para encontrar e atrair o público do negócio.

Julga-se pertinente a utilização da Matriz Ansoff nesse estudo, pois ela servirá como um guia no processo de disponibilidade de direcionamento de energia e custos para que tenha visibilidade e alcance o público-alvo de interesse.

A ferramenta SWOT, criada e desenvolvia por Albert Humphrey ${ }^{23}$, assim como a ferramenta analisada no tópico anterior (Modelo de Ansoff), também se preocupa com o ambiente externo, levando em consideração não apenas os fatores externos da empresa, como também os internos, sendo a base da gestão e do planejamento estratégico em muitas empresa e instituição.

Conforme aponta NUNES J. e CAVIQUE L. (2014), a análise SWOT é uma ferramenta de apoio com ampla aplicação no planejamento estratégico de empresas, para analisar demanda de mercado, sendo vista portanto, de forma geral, como uma abordagem prática e eficaz.

Sobre a análise SWOT, conforme pode ser observado na figura 3 abaixo, nota-se 4 características sobre a empresa e o ambiente interno e externo. Essa análise posiciona as

\footnotetext{
${ }^{22}$ Igor Ansoff, conhecido por ter criado a ferramenta de análise de produto e mercado, "Matriz Produto-Mercado" também conhecida como Modelo de Ansoff de planejamento estratégico.

23 Albert Humphrey autor e estudioso de administração, trouxe a tona a ferramenta de análise de mercado e ambiente interno e externo de uma empresa, Análise SiY̧T.
} 
avaliações cruzando informações de ambiente interno e externo com dificuldades ou contribuições para a empresa (NAKAGAWA24).

No primeiro quadrante temos que apontar as FORÇAS internas da empresa. O que caracteriza algo positivo para fortalecer o serviço que será prestado, e que teremos como principal base para fazer crescer a empresa. Espera-se um desempenho de produto/serviço com muito investimento e aprimoramentos para evolução, com grande credibilidade para trazer retorno financeiro para a empresa, sendo considerada o ponto forte da empresa.

Já no segundo quadrante, localizado ao lado do quadrante de forças, temos as FRAQUEZAS internas, que apresenta as preocupações e situações internas do negócio que desafiam o sucesso do empreendimento, e devem ser analisados constantemente para serem melhorados.

Logo abaixo das forças internas, temos o quadrante OPORTUNIDADES, que são os elementos externos ao ambiente interno da empresa, que são vistos como questões positivas a serem aproveitadas para melhorar e alavancar benefícios ao empreendimento. Os quadrantes relacionados ao ambiente externo, são aqueles, cujo controle fogem do alcance dos gestores, pois os mesmos acontecem em funções de atitudes externas às empresas.

Por fim, temos do lado do quadrante oportunidades, e abaixo do quadrante fraquezas, o quadrante AMEAÇAS, que leva em consideração os problemas que o ambiente externo pode interferir no negócio.

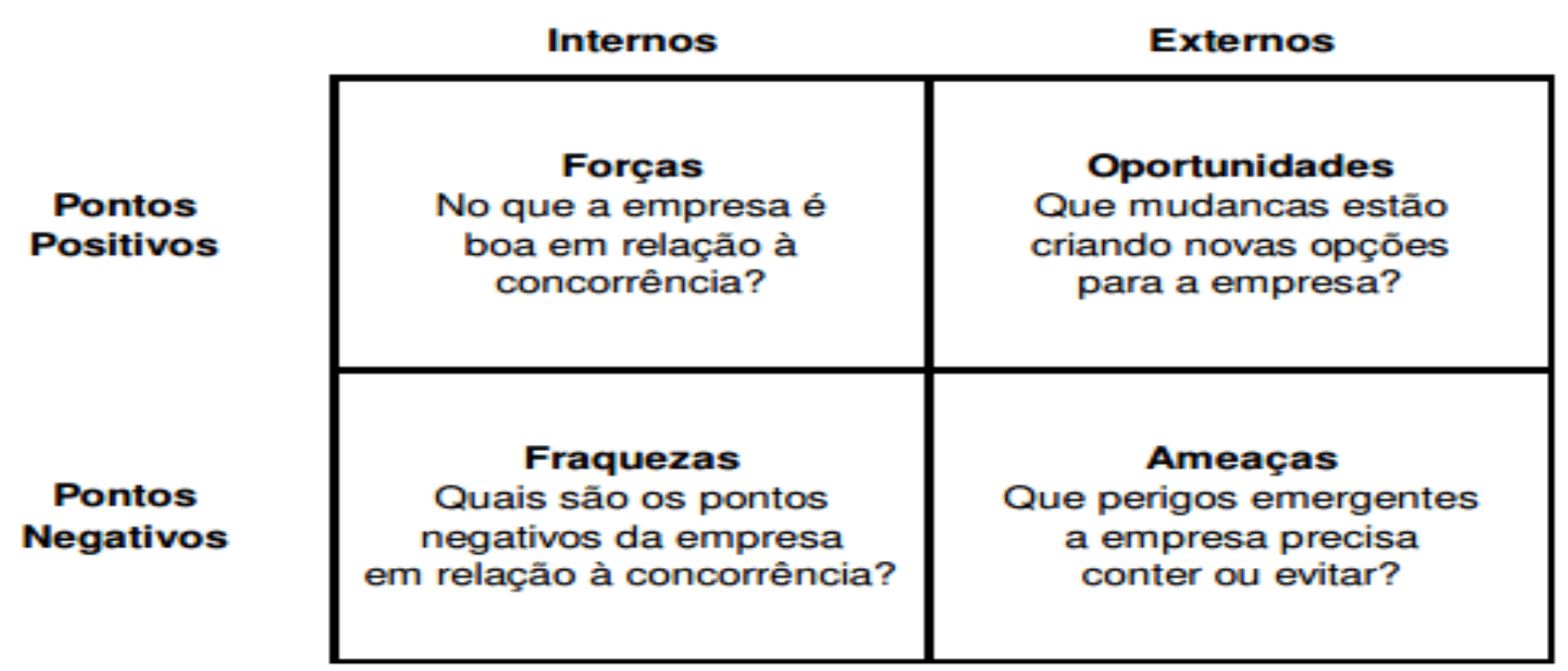

Figura 3: Formato da Matriz SWOT

Fonte: COHEN (2015)

\footnotetext{
${ }^{24}$ Marcelo NAKAGAWA, professor e coordenador do centro de empreendedorismo do INSPER, autor do material disponibilizado no site do SEBRAE. 
Para o empreendimento objeto desse trabalho, a análise SWOT ainda não foi aplicada, porém dada a sua relevância para a análise de viabilidade, a mesma será utilizada futuramente, diante a evolução deste estudo e da construção do plano de negócios do empreendimento.

\subsection{Ideia inicial do empreendimento}

As modalidades esportivas que estão sendo inicialmente consideradas como oferta no portfólio de serviços prestados pela empresa foram baseadas em três percepções consideradas relevantes para o bom funcionamento do todo a curto e médio prazo, além de abrir possibilidades de crescimento a longo prazo, porém na elaboração do Plano de Negócios haverá a realização de uma pesquisa de mercado, com a finalidade de validar a viabilidade mercadológica das mesmas.

Modalidades esportivas consideradas:

a. O badminton, escolhido inicialmente como o principal produto da empresa, foi assim considerado a princípio, em função de um apreço da empreendedora pela modalidade, em segundo lugar pela sua expressividade do crescimento na quantidade pessoas interessadas, já que é o esporte com o segundo maior número de praticantes no mundo, segundo informações do site suapesquisa.com25, e mesmo que no Brasil não tenha grande expressividade cultural, esse dado aponta sua inegável capacidade de envolvimento das pessoas pela sua prática. Por fim a avaliação do investimento inicial para os equipamentos que serão utilizados para as aulas e uso de espaço para montagem da quadra onde se pratica, indicam um investimento relativamente baixo, em comparação aos demais esportes de raquetes existentes como opção de oferecimento de aulas.

No caso do badminton, além da possibilidade de atender a demanda das pessoas que podem preferir aulas particulares em horários determinados, também pode permitir agregar um público maior, com aulas coletivas onde muitos alunos fazem a aula ao mesmo tempo. Neste cenário, além de se criar o propósito de desenvolver fisicamente e tecnicamente o desempenho de cada aluno/cliente na modalidade, constrói-se também uma abordagem de desenvolvimento no âmbito social, através da convivência com colegas de prática esportiva. Nesse contexto vem à tona os benefícios de motivação, no quesito de continuidade na participação das aulas.

b. Outro esporte que se tem perspectiva de incluir no negócio, é o Squash. Esse esporte vai de encontro com uma demanda diferenciada no quesito de poder aquisitivo do

\footnotetext{
${ }^{25} \mathrm{https}: / /$ www.suapesquisa.com/educacaoesportes/badminton.htm
} 
público alvo. É considerado o esporte mais saudável pela revista Forbes, e considerado um combatente do estresse por sua forma de jogabilidade, e é visto como um dos favoritos pelos executivos, em função da facilidade e flexibilidade dos horários para se praticar, visto que depende somente de dois jogadores para viabilizar a prática. É uma modalidade tida como perigosa para se fazer aula com mais de um aluno, por ter uma jogabilidade em um espaço pequeno e fechado, onde a alta velocidade da bola, que possui característica pequena, densa e maciça, caso atinja o jogador, provoca dor e lesão no local da pancada. Ou seja, em função da jogabilidade de risco apresentada, para pratica e oferecimento de aulas em segurança, deve-se considerar apenas as opções de aulas individuais ou em dupla, quantidade máxima de praticantes em um jogo oficial.

Além do mais, tem um alto índice de quebra de material de prática, já que constantemente o atleta entra em choque com a parede rebatendo sua raquete na mesma, pois por muitas vezes a bola fica muito próxima dela. Isso faz com que o custo com aquisição de material seja alto e corriqueiro, por parte do praticante, principalmente os iniciantes e que possuem pouca habilidade no jogo.

O Squash, levando em consideração as informações relatadas no parágrafo anterior, se torna uma prática que exige um valor mais elevado para o aluno/cliente que estiver interessado em praticá-lo, uma vez que demanda ter mais condições financeiras para conseguir manter sua atividade. É um esporte com caraterísticas culturais e perfil de jogabilidade com o propósito de atrair um público de classe econômica mais elevada (acima de 10 salários mínimos), com grande adesão de empresários, conforme relatado na reportagem da revista Forbes.

A estratégia de incluir o Squash, se torna muito atraente, primeiro porque os esportes podem ser considerados de uma mesma família (esportes de raquete), casando a ideia de unir essas duas modalidades em um mesmo espaço, com o propósito de abranger classes sociais diferentes, sendo que o Squash, atrairia a atenção e interesse de pessoas que tem maior poder aquisitivo e assim poderiam trazer para o negócio um maior retorno econômico, enquanto que o público-alvo da modalidade badminton, poderia pertencer a um grupo de clientes de menor poder aquisitivo, tornando o espaço com alta movimentação de pessoas ativas, trazendo visibilidade para o empreendimento.

c. A longo prazo, existe um projeto de inclusão da modalidade Tênis de Mesa, onde a proposta para esse estudo, é desenvolver um trabalho social sem custo para as crianças da comunidade, idealizado através de parcerias com o setor público e privado. Essa ideia tem como princípio, além de garantir que os valores da empresa sejam fortalecidos e coerentes, permitir que as crianças de hoje, se tornem pessoas ativas na fase adulta, e sejam conhecedoras dos 
esportes oferecidos pelo empreendimento aqui desenvolvido, dando base que a próxima geração se mantenha inserida na proposta da empresa.

\section{ASPECTOS METODOLÓGICOS}

Está sendo realizada uma revisão bibliográfica, que envolve de forma geral o assunto empreendedorismo, plano de negócios, e gestão esportiva. Também será feito uso da ferramenta de elaboração de projetos, denominado "Canvas", onde introduzirá o direcionamento de olhar crítico para situações existentes e necessidades da comunidade alvo escolhida.

Outra ferramenta de uso na administração, que também será utilizada para complementar a análise dos dados, é a "Matriz Produto-Mercado", também conhecida como "Matriz Ansoff" cujo nome tem origem em função de seu criador.

Ainda para embasar mais fortemente os dados que forem surgindo, esse presente estudo, pretende avaliar através dos apontamentos e informações considerados pela ferramenta da Matriz SWOT, levando em conta as questões dos ambientes internos e externos, que podem vir a influenciar o negócio.

Por fim, realizar pesquisas de mercado, utilizando o conceito dos 4P`s de Kotler, com caráter exploratório seguido do descritiva e casual, para corroborar as ideias do que será essencial para levantamento de dados quantitativos com especificidade nas características desse ambiente escolhido. Esse trabalho, conforme é retratado em "Fundamentos de Metodologia Científica" pela autora LAKATOS ${ }^{26}$ (2003), indica ser um artigo de natureza de análise:

Nesse tipo de artigo, o autor faz análise de cada elemento constitutivo do assunto e sua relação com o todo. "O técnico ou cientista procura descobrir e provar a verdadeira natureza do assunto e das relações entre suas partes" (Siqueira, 1969:61). A análise engloba: descrição, classificação e definição do assunto, tendo em vista a estrutura, a forma, o objetivo e a finalidade do tema. Entra em detalhes e apresenta exemplos. (LAKATOS E MARKONI, 2003, p. 261)

Estas características relatadas acima, serviram de base e alinhamento de ideias para a construção e desenvolvimento deste presente trabalho.

\section{RESULTADOS E DISCUSSÃO}

\footnotetext{
${ }^{26}$ Eva Maria Lakatos, graduada em Administração e Jornalismo. Mestre e Doutora em Ciências, foi uma brasileira pesquisadora, professora universitária e socióloga, especializada em Sociologia da Administração e Metodologia Científica.
} 


\subsection{Resultados Preliminares}

Para verificar o contexto no primeiro momento, foi realizada uma busca no site do Instituto Brasileiro Geografia Estatística (IBGE), o qual aponta que Frutal-MG tem uma população estimada de 59.496 pessoas no ano de 2019, sendo que dessas, $23 \%$ são profissionais com remuneração, e que a média salarial em 2017 era de 2,2 salários mínimos. Isso classifica a população média do local escolhido, como um grupo de consumidor preponderantes da classe social de consumidor D, conforme classificação de referência do próprio IBGE.

Foi realizado um levantamento de percepções através do "Business Model Canvas", que permitiu elaborar uma base personalizada de plano de negócios. Tendo como foco as características da cidade Frutal-MG, com o primeiro passo prático do estudo, foi obtido uma série de apontamentos baseados na cidade escolhida, como predefinição do público alvo de interesse, definição da proposta de valor, formas de se obter renda, entre outros, sendo eles elementos fundamentais para elaboração do próximo passo do estudo, que será elaborar uma pesquisa de mercado com a população para quantificar.

Com base nos propósitos levantados para o negócio idealizado, pode ser visualizado no Quadro 1 a seguir, a descrição geral das necessidades do negócio.

\begin{tabular}{|l|c|l|}
\hline \multicolumn{1}{|c|}{ Nome do Item } & \multicolumn{1}{|c|}{$\begin{array}{c}\text { Definição para o } \\
\text { Empreendimento }\end{array}$} & \multicolumn{1}{c|}{ Descrição Geral do Negócio } \\
\hline 1. Segmento de Clientes & Mercado Diversificado & Adultos trabalhadores; adolescentes; idosos. \\
\hline 2. Proposta de Valor & Performance; Novidades & Saúde; Lazer; Social. \\
\hline 3. Canais de Distribuição & Promoção de saúde e lazer & $\begin{array}{l}\text { Aulas de Esportes de Raquete; Organização de } \\
\text { eventos esportivos. }\end{array}$ \\
\hline $\begin{array}{l}\text { 4. Relacionamento com o } \\
\text { Cliente }\end{array}$ & Assistência personalizada & $\begin{array}{l}\text { Atender a demanda e necessidade personalizada de } \\
\text { cada aluno, com aulas individualizadas. }\end{array}$ \\
\hline 5. Fontes de Receitas & Taxa de utilização; Venda & $\begin{array}{l}\text { Cobrança de mensalidade, e venda de produtos } \\
\text { esportivos. }\end{array}$ \\
\hline 6. Recursos Chave & $\begin{array}{c}\text { Humano; Físico } \\
\text { Presença de profissionais capacitados; espaço } \\
\text { adequado e seguro para prática esportiva e materiais } \\
\text { esportivos de qualidade. }\end{array}$ \\
\hline 7. Atividades Chave & Serviços & $\begin{array}{l}\text { Oferecimento de atividades e eventos esportivos com } \\
\text { regularidade, e em horários que atendam a demanda } \\
\text { do público alvo. }\end{array}$ \\
\hline 8. Parceiros Chave & Redução de Riscos e & $\begin{array}{l}\text { Fazer parcerias com empresas locais, para incentivar } \\
\text { a participação nas atividades oferecidas. }\end{array}$ \\
\hline
\end{tabular}

Quadro 1: Business Model Canvas - Empreendimento Esportivo em Frutal-MG 
Fonte: Autora

Seguindo a lógica de Cecconello (2008), deve-se pensar e elaborar o planejamento das operações considerando os aspectos financeiros da empresa, com enfoque nas receitas, custos e despesas, e consequente dimensionamento da parte operacional.

Para a empresa objeto deste estudo, que se trata de uma prestadora de serviços no âmbito esportivo, os gastos que deverão ser considerados são os com referência à instalação inicial da empresa, como aquisição e preparação do local para oferecimento das aulas (quadra e estrutura com vestiários, piso adequado cobertura para maior segurança e qualidade na pratica esportiva, independentemente do tempo), compra de material esportivo essencial para oferecimento de boas aulas.

Além do investimento inicial, deve-se levar em consideração os custos da manutenção do local e materiais para aulas de qualidade, pagamento de funcionários para o bom andamento do estabelecimento (professores, auxiliar de limpeza, secretaria, contador), além de contas de despesas como energia, água, telefone, produtos de limpeza e material de escritório, impostos entre outros.

Atualmente identifica-se, através de uma pesquisa objetiva, por meio de uma busca na internet, constam na cidade de Frutal-MG, o número total de quinze estabelecimentos registrados na ferramenta de busca Google ${ }^{27}$, com foco voltado para prática esportiva atendendo adultos, sendo eles distribuídos entre academia de musculação (7), pilates (3), crossfit (2), yoga (1), lutas (1), dança (1). Com isso em mente, observa-se a possibilidade de introdução no mercado de empreendimento esportivo diferenciado, justificando assim o envolvimento de uma pesquisa de mercado no estudo, aprofundando dessa forma a coleta de maiores informações acerca desse interesse.

Logo, nesse primeiro momento, a análise superficial dessa ferramenta aponta que e empreendimento em questão pode ser considerado encaixado no quadrante tido como “diversificado" se levar em consideração que seu perfil de negócio é uma escola de modalidade esportiva de raquetes, ou seja algo inexistente na localização, sendo totalmente inovador tanto no quesito mercado como no quesito produto, ou ainda no quadrante desenvolvimento de produto, se for considerado um mercado existente de práticas de atividades físicas, onde inovador será apenas o produto, identificado como aulas de um esporte com manejo de raquetes.

\subsection{Discussão}

${ }^{27}$ Pesquisado no Google "academias em Frutal MG” e "praticar atividades físicas em Frutal MG” 
Dentro dos apontamentos coletados de outros trabalhos e estudos pesquisados, podese compreender que o processo de criação de um novo empreendimento, independente de qual natureza seja, apresenta riscos e perspectivas de sucesso. Certamente não é possível afirmar com garantias qual o caminho que esse negócio irá de fato seguir, mas é possível através de análises qualitativas e quantitativas através do plano de negócios verificar as possibilidades com maiores percentuais de sucesso.

Com esse trabalho desenhado, cria-se um norte de quais medidas são essenciais. E ao mesmo tempo que as informações vão sendo apresentadas, o projeto do empreendimento vai ser construído conjuntamente. Observar as informações especificas que serão levantadas sobre o tipo de negócio estudado, permitirá absorver definições sobre que tipo de esportes existem maiores condições de serem aceitos pela população, que tipos de promoções podem ser adequados, e variadas outras respostas buscando sempre o maior percentual de possibilidades de sucesso.

Por isso, dentro das expectativas criadas pelas leituras a discussão está toda voltada para como obter sucesso dentro do ramo esportivo.

\section{CONCLUSÃO}

Diante das pesquisas realizadas até momento, e considerando a avaliação dos dados iniciais levantados com a elaboração do Canvas, e aplicação de preliminar de outras ferramentas, além da revisão bibliográfica, para busca de dados e hipóteses realizadas, concluise que é possível analisar a viabilidade de um empreendimento esportivo através de um Plano de Negócios.

Como o presente estudo encontra-se em estágio inicial, ainda não é possível fazer qualquer juízo acerca da viabilidade econômico-financeiro do empreendimento esportivo objeto específico deste estudo, no entanto como já dito os resultados iniciais da presente pesquisa indicam que o Plano de Negócios se mostra uma metodologia adequada para análise de viabilidade. 


\section{REFERÊNCIAS}

CeCCOnello, A.R. \& AJZENTAL, A. A construção do Plano de Negócio. Ed. Saraiva $1^{\text {a }}$ ed. São Paulo: 2008.

COHEN, E. D. Um estudo de caso do uso do Marketing Multicanal num estabelecimento de confecções têxteis Disponível em:

https://www.researchgate.net/publication/321110208_Um_estudo_de_caso_do_uso_do_Mark eting_Multicanal_num_estabelecimento_de_confeccoes_texteis Acesso: em 16 out. 2019.

DORNELAS, José Carlos Assis, Empreendedorismo, transformando idéias em negócio. 3 ed.

Rio de Janeiro: Elsevier, v. 1. 2008. 300 p.

ELAINA, J. Igor Ansoff - Pai da Gestão Estratégica. Disponível em: https://www.portalgestao.com/artigos/6662-igor-ansoff-pai-da-gest\%C3\%A3o-estrat\%C3\%A9gica.html Acesso em: 30 set. 2019.

FAJERSZTAJN, Laís; VERAS, Mariana \& SALDIVA, Paulo Hilário Nascimento. Como as cidades podem favorecer ou dificultar a promoção da saúde de seus moradores? Estudos Avançados, [s.1.], v. 30, n. 86, p.7-27, abr. 2016. FapUNIFESP (SciELO).

http://dx.doi.org/10.1590/s0103-40142016.00100002. Disponível em:

http://www.scielo.br/pdf/ea/v30n86/0103-4014-ea-30-86-00007.pdf. Acesso em: 10 maio 2019.

FRANCO, Luiza. Menos de 40\% dos brasileiros praticam esporte ou atividade física. Folha de São Paulo: equilíbrio e saúde. São Paulo. 17 maio 2017. Disponível em: https://www1.folha.uol.com.br/equilibrioesaude/2017/05/1884820-menos-de-40-dosbrasileiros-praticam-esporte-ou-atividade-fisica.shtml. Acesso em: 10 maio 2019.

FRAZAO, D. Max Weber, sociólogo e economista alemão. Última atualização 16 agosto 2018. Disponível em: https://www.ebiografia.com/max_weber/.Acesso em: 30 set. 2019

GITMAN, Lawrence J. Princípios da administração financeira. São Paulo: Habra, 1997.

Instituto Brasileiro Geografia e Estatística. Panorama da cidade de Frutal-MG. Disponível em: https://cidades.ibge.gov.br/brasil/mg/frutal/panorama. Acesso em: 20 set. 2019.

KALLER, M. Entenda a importância do planejamento financeiro para sua empresa Disponível em: https://syhus.com.br/2015/04/14/entenda-a-importancia-do-planejamentofinanceiro-para-sua-empresa/ Acesso: em 16 out. 2019. 
LAKATOS, Eva Maria; MARCONI, Marina de Andrade. Fundamentos de metodologia científica. 5. ed. São Paulo: Atlas, 2003. Disponível em:

file:///Users/marialucianunesdeoliveira/Downloads/LAKATOS\%20-\%20MARCONI\%20$\% 20$ FUNDAMENTOS\%20DE\%20METODOLOGIA\%20CIENTIFICA.pdf. Acesso em: 13 out. 2019.

Ministério do Esporte. DIESPORTE: diagnóstico nacional do esporte. 2015. Pesquisa elaborada pelo IBGE em 2013. Disponível em: http://www.esporte.gov.br/diesporte/7.php. Acesso em: 10 maio 2019.

MINTZBERG, H.; Quinn, J.B. The strategy process: concepts, contexts, and cases. Prentice-Hall, Inc., 3rdedition, New Jersey: NY,1996.

NAKAGAWA, M. Ferramenta: Análise SWOT. Site do SEBRAE. Disponível em: https://m.sebrae.com.br/Sebrae/Portal Sebrae/Anexos/ME_Analise-Swot.PDF Acesso em 30 set. 2019.

NUNES J. e CAVIQUE L., Plano de marketing, estratégia em Acção, Lisboa: Dom Quixote, 2001.Vilhena, 2014.

OLIVEIRA, G.; SILVA, D. A. S.; MAGGI, R M.; PETROSKI, E. L. \& FARIAS, J. M. Fatores sociodemográficos e de aptidão física associados a baixos níveis de atividade física em adolescentes de uma cidade do sul do Brasil. Reveducfis v23, N4, P. 635-645, $4^{\circ}$ trim. 2012, disponível em: http://ojs.uem.br/ojs/index.php/reeducais/article/view/17510/11091. Acesso em: 10 maio 2019.

OSTERWALDER, A. Value Proposition Design - Our Next Book Launching This Fall. Disponível em: http://businessmodelalchemist.com/ Acesso em: 13 out. 2019

PIERON, Maurice. Estilo de Vida, Prática de Atividades Físicas e Esportivas qualidade de vida. Fitness \& Performance Journal, Rio de Janeiro, v. 3, n. 1, p.10-17, jan. 2004.

Disponível em: https://dialnet.unirioja.es/descarga/articulo/2953114.pdf. Acesso em: 10 maio 2019.

SAMULSKI, D. M; NOCE, F. A importância da atividade física para saúde e qualidade de vida: Um estudo entre professores, alunos e funcionários da UFMG. Disponível em: http://rbafs.org.br/RBAFS/article/view/992/1140. Acesso em: 13 out. 2019.

SOUZA, L. Localização é a chave para o sucesso do negócio. Disponível em: https://atarde.uol.com.br/economia/noticias/1340552-localizacao-e-chave-para-o-sucesso-donegocio. Acesso em: 30 set. 2019.

TEIXEIRA, H. J.; SALOMÃO, S. M.; TEIXEIRA, C. J. Fundamentos de Administração: a busca do essencial. Ed. Elsevier $1^{\text {a }}$ ed. Rio de Janeiro: 2010. 


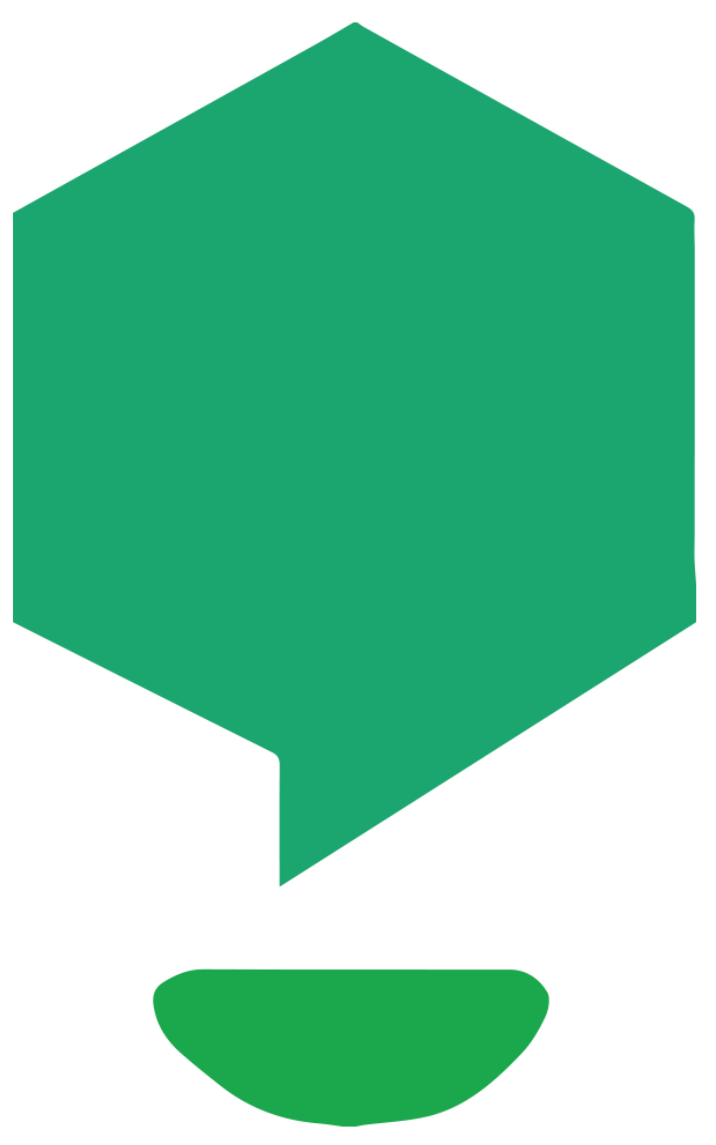



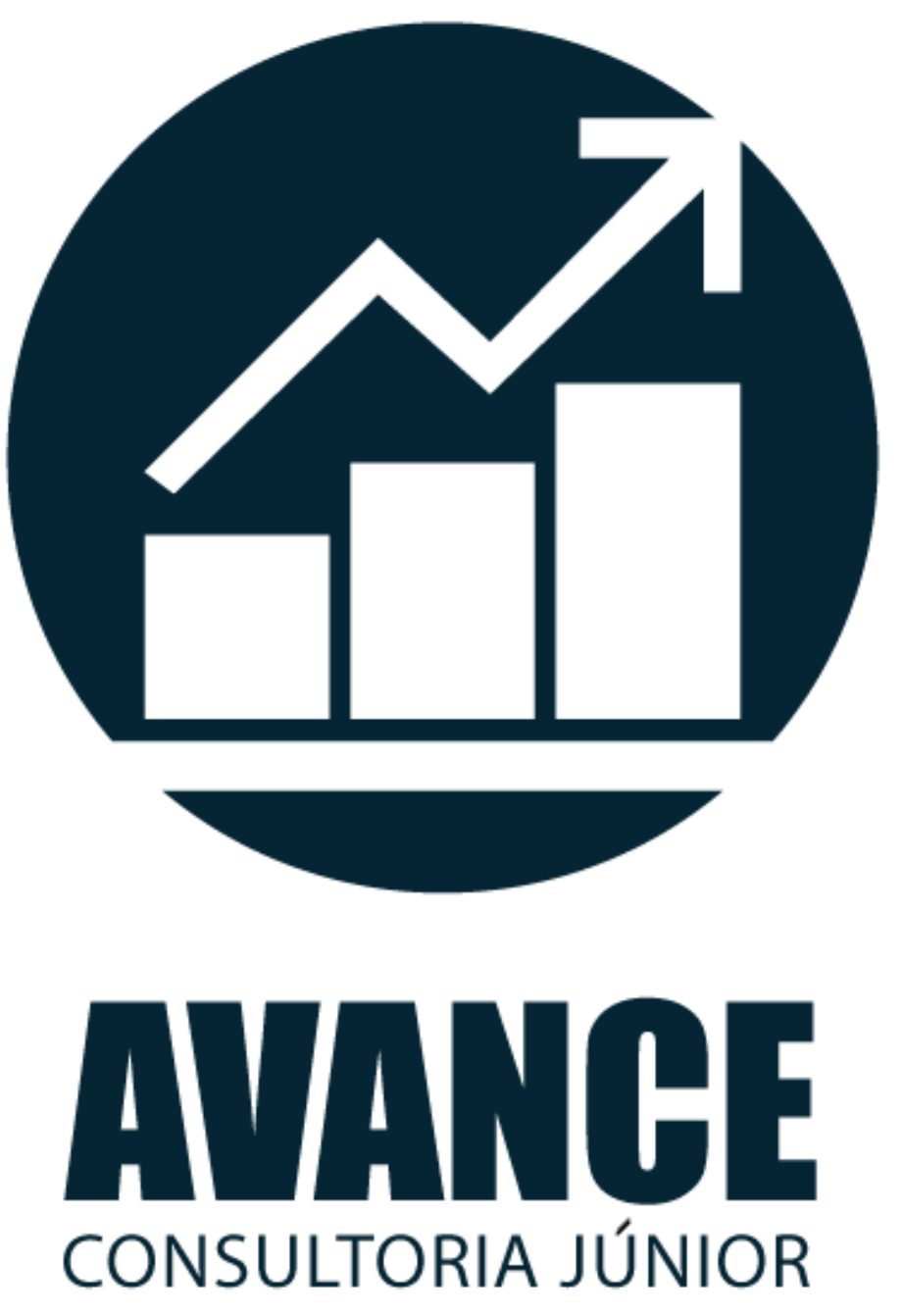
ISBN: 978-85-572-2373-8

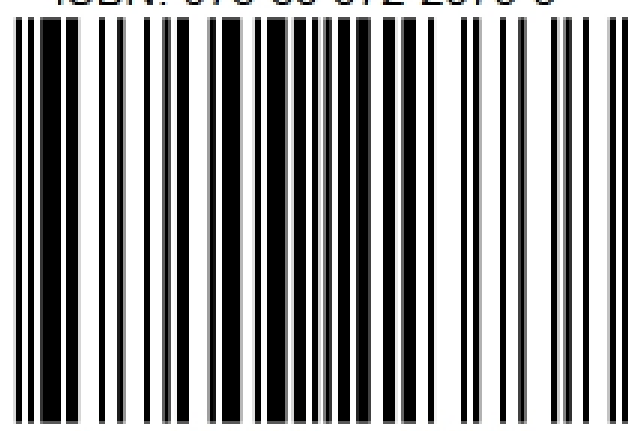

$\begin{array}{lll}9 & 788557 & 223738\end{array}$ 